Illinois State University

ISU ReD: Research and eData

Theses and Dissertations

$12-3-2013$

\title{
Student Internet Speech: Where Does the Schoolyard End in the Cyberworld?
}

Thomas D. Denny

Illinois State University

Follow this and additional works at: https://ir.library.illinoisstate.edu/etd

Part of the Other Educational Administration and Supervision Commons

\section{Recommended Citation}

Denny, Thomas D., "Student Internet Speech: Where Does the Schoolyard End in the Cyberworld?" (2013). Theses and Dissertations. 382.

https://ir.library.illinoisstate.edu/etd/382

This Dissertation is brought to you for free and open access by ISU ReD: Research and eData. It has been accepted for inclusion in Theses and Dissertations by an authorized administrator of ISU ReD: Research and eData. For more information, please contact ISUReD@ilstu.edu. 


\title{
STUDENT INTERNET SPEECH: WHERE DOES THE SCHOOLYARD END IN THE CYBERWORLD?
}

\author{
Thomas D. Denny
}

143 Pages

December 2013

This study examines student internet speech that originates off-campus but results in discipline from school. The history of the issue of student speech is explored to set the foundation for the current issue. In the absence of a Supreme Court ruling on student offcampus internet speech, cases reaching the Federal level are explored in search of commonalities. The resulting information is synthesized to create two artifacts. The first is a matrix to summarize the rulings and rationale of the cases. The second is a reference tool to guide administrators in dealing with similar student speech cases. 
STUDENT INTERNET SPEECH: WHERE DOES THE SCHOOLYARD

END IN THE CYBERWORLD?

THOMAS D. DENNY

A Dissertation Submitted in Partial

Fulfillment of the Requirements

for the Degree of

DOCTOR OF EDUCATION

Department of Educational Administration and Foundations

ILLINOIS STATE UNIVERSITY 
Copyright 2013 Thomas D. Denny 
STUDENT INTERNET SPEECH: WHERE DOES THE SCHOOLYARD

END IN THE CYBERWORLD?

THOMAS D. DENNY

COMMITTEE MEMBERS

Elizabeth Lugg, Chair

John Presley

Neil Sappington

Guy Banicki 


\section{ACKNOWLEDGMENTS}

I would like to thank my wife Mara for her support, patience, and extra efforts

during this process. To my children Tessa, Tyler, and Tristan, thanks for understanding why I was gone so much. I also thank my parents, Jay Denny and Donna Pleckham, for stressing the importance of education to me as a child. To all the great teachers and coaches I have had in my life, I thank you as well. I hope my children are as fortunate as I as they progress through their educations.

T.D.D. 


\section{CONTENTS}

Page

ACKNOWLEDGEMENTS

CONTENTS

TABLES $\quad$ iv

\section{CHAPTER}

I. INTRODUCTION 1

School Discipline $\quad 1$

Framework 3

Purpose of Study $\quad 5$

Methodology 7

Definition of Terminology 8

Key Organization/ Sources of Information $\quad 12$

Limitations of the Study 13

Summary 13

$\begin{array}{ll}\text { II. STUDENT PROTECTIONS } & 15\end{array}$

First Amendment 15

Fourth Amendment 16

Fourteenth Amendment $\quad 17$

Goss v. Lopez $\quad 20$

Right to Privacy - Brandeis 22

Olmstead v. United States Dissent 25

Current Legal Analysis $\quad 26$

III. SUPREME COURT JURISPRUDENCE ON STUDENT SPEECH 41

In Loco Parentis 41

First Amendment Cases $\quad 42$

Fourth Amendment Cases $\quad 52$ 
IV. RECENT ISSUES FOR SCHOOL AUTHORITY 62

Off-Campus Speech That Makes Its Way On Campus 62

Courts Side With Students $\quad 62$

Courts Side With Schools $\quad 85$

V. IMPLICATIONS OF CURRENT ISSUES 101

Commonalities and Differences From Rulings 101

Guidelines to Consider - Administrative Practice $\quad 109$

Administrative Practice - Policy 111

Implications 113

Philosophy of Education/ General Leadership $\quad 114$

$\begin{array}{ll}\text { Finance } & 120\end{array}$

Policy/ Legal 122

Community Relations 128

Curriculum \& Instruction $\quad 129$

Conclusions/ Predictions 131

REFERENCES

Appendix A: Federal Level Case Matrix 136

Appendix B: Administrator Consideration Tool 142 


\section{TABLES}

Table $\quad$ Page

1. Case Matrix 103

2. Administrative Consideration Tool 


\section{CHAPTER I \\ INTRODUCTION \\ School Discipline}

The problem under consideration in this study is the issue of off-campus speech that makes its way onto school campuses and elicits some sort of action from the school administration. An examination of current legal challenges to school discipline of student expression through off campus technology that makes its way on to school grounds will expose the conundrum faced by educators today. Current cases will be summarized and then compared for similarities and differences to offer guidelines for current administrators to work by. The Supreme Court as recently as 2012 decided not to take up the issue of school discipline of students for off-campus technologically related speech, so there is no direct guidance on the topic in that respect. An examination of lower court findings, however, will be beneficial for educators to understand the rationale that led the various courts to make the decisions that have been reached on the issue, which have seemingly been inconsistent and contradictory at times.

This study seeks to provide a reference for administrators as to important considerations regarding the regulation of student behavior and the rapidly changing technological age in which we live. Educators should realize that with, "...increasing litigation over the exercise of school authority of student off-campus speech...policy 
development is insufficient..." ${ }^{1}$ on its own. Policies are often out dated by the time they are printed in the field of technology. Educators will also need an understanding of the various lower court findings and the rationale used to reach them to effectively address student expression issues regarding technology and the discipline associated with such incidents.

There are specific questions practicing administrators should bear in mind during the investigation of any potential off-campus internet speech case when considering to issue discipline. These questions include, but are not limited to the following: (1) Is this protected First Amendment speech; (2) Where did this speech originate; (3) Who actually made the commentary; (4) What was the intent of the comment; (5) Who was impacted by the comment and how; (6) Did the comment enter the schoolhouse in some form; (7) What was the impact of the comment; (8) Was the school day disrupted and if so, to what extent; (9) Is the discipline for the disruption or for who the comment was directed towards; and (10) Was the comment made in jest. This list is daunting on its own, let alone when faced with an actual dilemma regarding a student comment and the impending action to take.

This study will seek to provide advice as to the most prevalent considerations to be given when addressing off-campus expressions issues that make their way on school grounds. A tool to guide administrators as to which questions to ask, and when to ask them to some extent, will aid greatly in sifting through this mound of considerations.

\footnotetext{
${ }^{1}$ Philip T.K. Daniel, and Silas McCormick, "Technological Advances, Student Expression, and the Authority of School Officials", West's Education Law Reporter, 248 Ed. Law Rep. 553, November 12, 2009, p. 2.
} 


\section{Framework}

While past cases have set some standards in terms of the degree to which school authority extends, the technological era in which we live leaves many more obstacles for schools and students alike to navigate. Specifically, the issue of off-campus internet speech that makes its way on campus provides many potential pitfalls for school administrators to beware of.

While it would seem logical that over time this issue would move into clearer focus, the reality is quite to the contrary. Court cases leading up to today have certainly addressed issues as they have arisen such as can students wear symbolic armbands in protest of societal issues? Can students make statements or take actions that significantly disrupt the educational environment in the name of free speech? Current media portrayals would lead people to believe the foundation of public education is in a shaky position. Social networking and technology such as cell phones have so radically changed the nature of communication, traditional definitions of school responsibilities and boundaries no longer accurately fit.

The current age is not going to wait for society to debate and articulate where it envisions this struggle moving. Rather, technology is going to move ahead and schools will need to make decisions based on yesterday's views until the Supreme Court decides tomorrow's direction. "The unintended consequences of the Information Age, however, have caused a dysbiosis of knowledge and information and, thereby, inverted the roles of the significant actors in the pedagogical enterprise. This issue is not easily resolved because even when new policies and/ or new training practices are executed they are likely to have a short shelf life. Collectively, it is clear that the impact of technology on 
student expression rights, or administrative authority to control expression, has not yet resulted in a set of definitive or prevailing legal patterns." ${ }^{2}$ As the Supreme Court declined the opportunity to examine a series of cases on the topic in January 2012, school administrators will be left to navigate very gray waters in dealing with the related issues. Francisco M. Negron, as lead counsel in authoring an Amici Curiae brief on behalf of the National School Boards Association, American Association of School Administrators, American School Counselor Association, The Gay, Lesbian, and Straight Education Association and a half of dozen other school personnel related organizations and associations, wrote in the hope that the Supreme Court would take up a series of related cases presented together and argued that the Supreme Court's guidance, "...is critical to assisting school officials in understanding how they may regulate the student expression that now pervades social networking forums without contravening the time-honored principles of the First Amendment." ${ }^{3}$ Nowhere is the delicate task of balancing between student rights and educator responsibilities more evident than in the intersection of technology and education. One of the most difficult issues in that intersection that has emerged regards in what circumstances a school may regulate a student's off-campus activity when, due to technology, that activity impacts the school. ${ }^{4}$

\footnotetext{
${ }^{2}$ PhilipT.K. Daniel, and Silas McCormick, "Technological Advances, Student Expression, and the Authority of School Officials", West's Education Law Reporter, 248 Ed. Law Rep. 553, November 12, 2009, p. 2.

${ }^{3}$ Francisco Negron, Amici Curiae Brief In The Supreme Court of the United States No. 11-502, November 2, 2011, p. 3.

${ }^{4}$ Philip T.K. Daniel, and Silas McCormick, "Technological Advances, Student Expression, and the Authority of School Officials", West's Education Law Reporter, 248 Ed. Law Rep. 553, November 12, 2009 , p. 3 .
} 


\section{Purpose of study}

The school system is asked to do more for students while continuing to receive less from the various levels of government in terms of resources and support. On the one hand, schools are charged with the expectation that all students attend school in a safe and bully free environment so no child gets left behind. On the other hand, schools are expected not to infringe upon the rights of students to express themselves at home and on their own computers and phones. The problem arises that the technological era we live in has severely blurred those traditional geographic boundaries that separate the school from the home. School administrators are left to balance the rights of the individual student with the rights of the large student population in this constantly changing technological world.

In this study the author will examine the findings of various federal courts regarding issues of student speech, both on and off campus, that have provided the foundation by which courts judge current off-campus student expression that makes its way into the schools. The author will then use the established jurisprudence as a filter by which to categorize the more recent off-campus student speech cases that have come on campus. Finally, the study aims to provide administrators with some guidance in shaping both policy and practice in dealing with these cases as they arise. Such guidance will be essential for administrators until the time the Supreme Court decides to address the issue and more clearly define the role schools should be playing in this scenario.

This study seeks to provide a reference for administrators as to important considerations regarding the regulation of student behavior and the rapidly changing technological age in which we live. While such a tool will not be a substitute for a 
definitive Supreme Court ruling, it may aid administrators in dealing with the uncertainties of this issue until such time as a ruling is made. Educators should realize that with, "...increasing litigation over the exercise of school authority of student offcampus speech...policy development is insufficient" ${ }^{5}$ on its own. Policies are often outdated by the time they are printed in the field of technology. Educators will also need an understanding of the various lower court findings and the rationale used to reach them to effectively address student expression issues regarding technology and the discipline associated with such incidents. This study will seek to provide advice as to the most prevalent considerations to be given when addressing off-campus expressions issues that make their way on school grounds.

\section{a. Research Questions}

i. What is the Supreme Court jurisprudence to date regarding student speech? What standards have school administrators been left to work with as a result?

ii. What legal challenges have been made to school authority in the areas of student discipline for off-campus speech that has made its way on campus?

iii. What are/is the current outcome(s) of cases regarding the balance of students rights vs. school authority in the area of student discipline for off-campus speech that has made its way on campus?

iv. How do(es) the current outcome(s) of cases regarding school authority vs. student rights impact the educational setting in the area of student discipline for off-campus speech that has made its way on campus?

b. Outline of Study

i. Chapter 1 - Introduction

ii. Chapter 2 -Student Protections

iii. Chapter 3 - Supreme Court Jurisprudence on Student Speech

iv. Chapter 4-Recent Federal Level Court Cases

v. Chapter 5 - Implications \& Suggestions

\footnotetext{
${ }^{5}$ Philip T.K. Daniel, and Silas McCormick, "Technological Advances, Student Expression, and the Authority of School Officials", West's Education Law Reporter, 248 Ed. Law Rep. 553, November 12, 2009 , p. 2.
} 


\section{Methodology}

This study seeks to examine cases that have reached the Federal Level and have dealt with the issue of student off-campus speech that is technologically related and has resulted in discipline being handed down at school for the speech. On a case by case basis, the items will be summarized as to the key aspects of the case as well as the outcome or findings of the case. It is important to note that many elements may need to be considered in examining these cases including were the speech was made public or posted to the internet, whose machine was used for the speech, how it was discovered, the actual content of the speech, the implied content of the speech, how the school found out about the speech, to name a few elements. There is no clear cut standard of content even to consider in these cases, as a student posted a drawing of a teacher getting shot and the courts found in favor of the student. Rather the courts hear each case on its own merits and use a number of criteria to determine if a school overstepped their bounds in issuing discipline. The difficult aspect for school administrators is that there is no clear cut decision to follow, but rather a series of somewhat contradictory rulings that blur the lines for administrators more than clear them.

In addition to the individual facts of each case and ruling being summarized, the case will be compared to find similarities and differences in both the cases and the courts decisions so that the practicing administrators might be able to interpret some guidelines from which to act by. There are previous court cases by which the lower Federal Courts have based their decisions. However, there seems to be some contradictory findings by the same guidelines. In the absence of a Supreme Court ruling on the matter, a 
comparison of cases that have reached the Federal level will yield valuable insight for school administrators to formulate policy and guide practice by.

\section{Definition of Terminology}

A) Act - An act that is intended to create, transfer, or extinguish a right and that is effective in law for that purpose; the exercise of a legal power. ${ }^{6}$

B) Administrative Search - A search of public or commercial premises carried out by a regulatory authority to enforce compliance with health, safety, or security regulations. The probable cause required for an administrative search is less stringent than that required for a search incident to a criminal investigation. Also termed regulatory search; inspection search. ${ }^{7}$

C) Amicus Curiae - One (as a professional person or organization) that is not a party to a particular litigation but that is permitted by the court to advise it in respect to some matter of law that directly affects the case in question. ${ }^{8}$

D) Appeal - A proceeding undertaken to have a decision reconsidered by a higher authority; esp., the submission of a lower court's or agency's decision to a higher court for review and possible reversal. ${ }^{9}$

E) Authority - The right or permission to act legally on another's behalf ${ }^{10}$

\footnotetext{
${ }^{6}$ Blacks Law Dictionary $\left(9^{\text {th }}\right.$ Ed., 2009) retrieved from: http://campus.westlaw.com.proxy.lib.ilstu.edu/search/default.wl?rs=WLW12.04\&db=BLACKS\&vr=2.0\&r $\mathrm{p}=\% 2$ fsearch $\% 2$ fdefault. $w 1 \& \mathrm{sp}=000577844-2000 \& \mathrm{fn}=$ top \&mt=CampusLaw\&sv=Split. Accessed 4-2712. 
F) Circuit Court - A court usually having jurisdiction over several counties, districts, or states, and holding sessions in all those areas ${ }^{11}$

G) Constitution - 1. The fundamental and organic law of a nation or state that establishes the institutions and apparatus of government, defines the scope of governmental sovereign powers, and guarantees individual civil rights and civil liberties. 2. The written instrument embodying this fundamental law, together with any formal amendments. ${ }^{12}$

H) District Court - A trial court having general jurisdiction within its judicial district. $^{13}$

I) Due Process - The conduct of legal proceedings according to established rules and principles for the protection and enforcement of private rights, including notice and the right to a fair hearing before a tribunal with the power to decide the case. ${ }^{14}$

J) First Amendment - The constitutional amendment, ratified with the Bill of Rights in 1791, guaranteeing the freedoms of speech, religion, press, assembly, and petition. ${ }^{15}$

K) Fourth Amendment - The constitutional amendment, ratified with the Bill of Rights in 1791, prohibiting unreasonable searches and seizures and the issuance of warrants without probable cause. ${ }^{16}$

\footnotetext{
${ }^{11}$ Ibid

${ }^{12}$ Ibid.

${ }^{13}$ Ibid.

${ }^{14}$ Ibid.

${ }^{15}$ Ibid.

${ }^{16}$ Ibid.
} 
L) Fourteenth Amendment - The constitutional amendment, ratified in 1868, whose primary provisions effectively apply the Bill of Rights to the states by prohibiting states from denying due process and equal protection and from abridging the privileges and immunities of U.S. citizenship. ${ }^{17}$ The amendment also gave Congress the power to enforce these provisions, leading to legislation such as the civil-rights acts.

M) In Loco Parentis - Of, relating to, or acting as a temporary guardian or caretaker of a child, taking on all or some of the responsibilities of a parent. The Supreme Court has recognized that during the school day, a teacher or administrator may act in loco parentis. ${ }^{18}$

N) Jurisprudence - 1. Originally (in the 18th century), the study of the first principles of the law of nature, the civil law, and the law of nations. 2. More modernly, the study of the general or fundamental elements of a particular legal system, as opposed to its practical and concrete details. 3. The study of legal systems in general. 4. Judicial precedents considered collectively. 5. In German literature, the whole of legal knowledge. 6. A system, body, or division of law. 7. CASELAW. ${ }^{19}$

O) Nexus - A connection or link, often a causal one. ${ }^{20}$

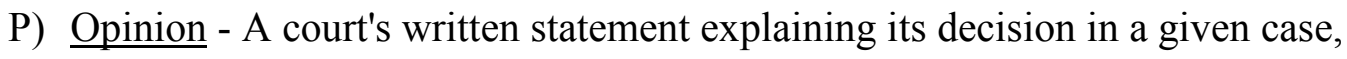
usu. including the statement of facts, points of law, rationale, and dicta. ${ }^{21}$

\footnotetext{
${ }^{17}$ Ibid.

${ }^{18}$ Ibid.

${ }^{19}$ Ibid.

${ }^{20}$ Ibid.

${ }^{21}$ Ibid.
} 
Q) Privacy - The condition or state of being free from public attention to intrusion into or interference with one's acts or decisions. ${ }^{22}$

R) Probable Cause - A reasonable ground to suspect that a person has committed or is committing a crime or that a place contains specific items connected with a crime. Under the Fourth Amendment, probable cause - which amounts to more than a bare suspicion but less than evidence that would justify a conviction - must be shown before an arrest warrant or search warrant may be issued. $^{23}$

S) Reasonable Suspicion - A particularized and objective basis, supported by specific and articulable facts, for suspecting a person of criminal activity. A police officer must have a reasonable suspicion to stop a person in a public place. $^{24}$

T) School Official - Public school administrator or designee who deal with students in disciplinary matters.

U) Search - Criminal procedure. An examination of a person's body, property, or other area that the person would reasonably be expected to consider as private, conducted by a law-enforcement officer for the purpose of finding evidence of a crime. Because the Fourth Amendment prohibits unreasonable searches (as well as seizures), a search cannot ordinarily be conducted without probable cause. $^{25}$

${ }^{22}$ Ibid.

${ }^{23} \mathrm{Ibid}$.

${ }^{24}$ Ibid.

${ }^{25}$ Ibid. 
V) Seizure - The act or an instance of taking possession of a person or property by legal right or process; esp., in constitutional law, a confiscation or arrest that may interfere with a person's reasonable expectation of privacy. ${ }^{26}$

W) Supreme Court of the United States - The court of last resort in the federal system, whose members are appointed by the President and approved by the Senate. ${ }^{27}$

X) Suspicion - The apprehension or imagination of the existence of something wrong based only on inconclusive or slight evidence, or possibly even no evidence. $^{28}$

Y) Trial Court - A court of original jurisdiction where the evidence is first received and considered. ${ }^{29}$

Z) Warrant - A writ directing or authorizing someone to do an act, esp. one directing a law enforcer to make an arrest, a search, or a seizure. ${ }^{30}$

\section{Key Organization/ Sources of Information}

The primary source of information in this study was federal cases relating to offcampus internet speech and public schools. These cases were gathered from a variety of web based sources that began with general data base searches via the Illinois State University Millner Library Website, and the School Law page in particular. These include utilizing the EBSCOHost search features and databases such as JSTOR and

\footnotetext{
${ }^{26}$ Ibid.

${ }^{27}$ Ibid.

${ }^{28}$ Ibid.

${ }^{29}$ Ibid.

${ }^{30}$ Ibid.
} 
ERIC. The legal specific research also involved sources such as online editions of the West's Education Law Reporter and the online edition of Black's Law Dictionary.

Web based sources include:

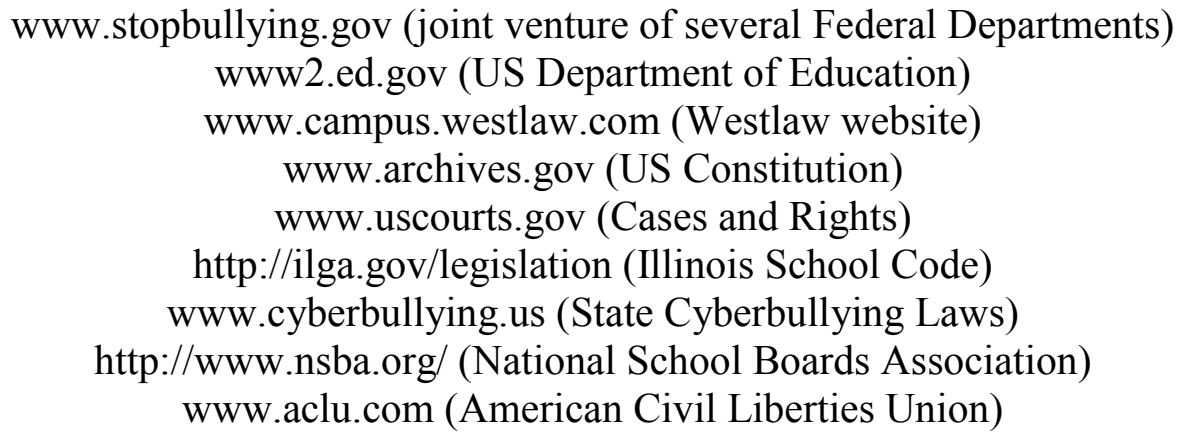

\section{Limitations of the Study}

This study is limited to court cases that have reached the Federal level in regards to off campus speech that have resulted in discipline from the schools. The limit of Federal level cases will be utilized to provide more universal applicability than state level cases as well as to provide precedence to a wider audience. Additionally, the divided results at the Federal level may ultimately lead the United States Supreme Court to decide and hear a case on the issue at some point. The study will examine those federal level rulings that have been made to date and attempt to provide direction for school administrators in dealing with the issue. The Supreme Court declined the opportunity to hear a cluster of cases on this topic early in 2012 so the study is limited in that there is no seminal Supreme Court decision from which to guide practice in this rather new technological area that school administrators deal with.

\section{Summary}

The school system is asked to do more for students while continuing to receive less from the various levels of government in terms of resources and support. On the one 
hand, schools are charged with the expectation that all students attend school in a safe and bully free environment so no child gets left behind. On the other hand, schools are expected not to infringe upon the rights of students to express themselves at home and on their own computers and phones. The problem arises that the technological era we live in has severely blurred those traditional geographic boundaries that separate the school from the home. School administrators are left to balance the rights of the individual student with the rights of the large student population in this constantly changing technological world. This study attempts to explain the development of the educational system to demonstrate how the current system came to be. Second, the study will examine the findings of various federal courts regarding issues of off campus speech that resulted in discipline. Finally, the study aims to provide administrators with resources to aid in shaping both policy and practice in dealing with these cases as they arise. Such resources will be essential for administrators until the time the Supreme Court decides to address the issue. 


\section{CHAPTER II}

\section{STUDENT PROTECTIONS}

Students have many rights which are the same as any other person on the street. The case of Tinker ET AL. v. Des Moines Independent Community School District in 1969 determined that, "It can hardly be argued that either students or teachers shed their constitutional rights to freedom of speech or expression at the schoolhouse gate." 31 While this may seem to indicate that the school student has the same rights as anyone else, the court also pointed out in the Tinker case that those rights must be, "... applied in light of the special characteristics of the school environment." ${ }^{32}$ The duplicity in this one decision reflects the reality of the school setting. The following documents and cases demonstrate what specific rights students possess.

\section{First Amendment}

The first amendment of the United States Constitution deals with five freedoms of United States citizens. ${ }^{33}$ Specifically the First Amendment states that, "Congress shall make no law respecting an establishment of religion, or prohibiting the free exercise thereof; or abridging the freedom of speech, or of the press; or the right of the people to peaceably assemble, and to petition the Government for a redress of grievances."34

\footnotetext{
${ }^{31}$ Tinker v. Des Moines Independent Community School District, 393 U.S. 507 (1969).

32 Tinker v. Des Moines Independent Community School District, 393 U.S. 507 (1969).

${ }^{33}$ U.S. Constitution, amend. 1.

${ }^{34}$ U.S. Constitution, amend. 1.
} 
As the present study is concerned with the issue of student internet speech, an understanding of the role of the First Amendment in public schools is essential. ${ }^{35}$ Specifically, the section of the Amendment that states the government may not pass any law prohibiting or limiting the freedom of speech. While this is true for the general public, the courts have decided that school students do not have exactly the same rights. The duty of the schools to educate the youth of the nation takes precedent in certain situations over the free speech rights of individual students.

The seminal case for public schools regarding free speech was Tinker v. Des Moines Independent Community School District in 1969. The Supreme Court set the bar for public school authority in regulating speech at a level such that discipline may be assigned once speech, “...materially and substantially interferes with the requirements of appropriate discipline in the operation of the school." ${ }^{, 36}$ While this has become the test for determining discipline in regards to speech issues, this exact phrase also is used to judge technological issues. The courts have demonstrated a willingness to support school discipline when schools can demonstrate that such a disruption has occurred or could reasonably be suspected.

\section{Fourth Amendment}

The Constitutional Amendment that protects the public from random searches by the government is the fourth amendment. The fourth amendment protects, “...the right of the people to be secure in their persons, houses, papers, and effects against unreasonable searches and seizures, shall not be violated, and no warrants shall issue, but upon probable cause, supported by oath or affirmation, and particularly describing the place to

\footnotetext{
${ }^{35}$ U.S. Constitution, amend. 4.

${ }^{36}$ Tinker v. Des Moines Independent Community School District, 393 U.S. 510 (1969).
} 
be searched, and the person or things to be seized. ${ }^{37}$ To the ordinary United States citizen this means the government or its agents cannot conduct a search unless there is probable cause of finding wrongdoing. The standard is different for school children.

Through the years, the courts have decided that schools must have the ability to deal with unexpected and varying circumstances without the standard of probable cause. The case of New Jersey v. T.L.O. set the standard for schools to search children at reasonable suspicion. ${ }^{38}$ The courts have gone further and defined the term reasonable as being a likely hood that the contraband sought could be found. The clarification has also been made through various cases that the search must be reasonable at inception, when it begins, and in scope, how far it is taken. Various cases that have reached the Supreme Court have given some direction to this general guideline.

Most recently, the Safford Unified School District \#1 v. Redding case which the Supreme Court decision in 2009 determined that strip searching a 13 year old looking for ibuprofen may have been reasonable at inception but was not reasonable in scope. ${ }^{39}$ The good that could be hoped to be gained by finding ibuprofen on a young teenage girl did not outweigh the trauma of a strip search to that same young girl. In short, the schools do not exercise complete and unchecked control over the students they work with.

\section{Fourteenth Amendment}

The Fourteenth Amendment of the US Constitution is one of the reconstruction amendments that passed after the Civil War and was intended to protect the rights of all people, among other functions. A thorough exploration of the Fourteenth Amendment

\footnotetext{
${ }^{37}$ U.S. Constitution, amend. 4.

${ }^{38}$ New Jersey v. T.L.O., 469 U.S. 325 (1985).

${ }^{39}$ Safford Unified School District \#1 v. April Redding, 129 U.S. 2633 (2009).
} 
would be a dissertation unto itself and beyond the need of this study. However, understanding the basics of the amendment and the application of the amendment will clarify why it appears in nearly every lawsuit brought by students against school districts in regards to off-campus internet speech.

The Fourteenth Amendment was written to address four issues which included protecting the rights of recently freed slaves, overturning the three-fifths clause of the Constitution, to forbid southern insurrectionists from holding Federal office, and to address southern debt incurred during the Civil War. ${ }^{40}$ The first section of the Amendment is pertinent to this study and reads:

"All persons born or naturalized in the United States, and subject to the jurisdiction thereof, are citizens of the United States and of the state wherein they reside. No state shall make or enforce any law which shall abridge the privileges or immunities of citizens of the United States; nor shall any state deprive any person of life, liberty, or property, without due process of law; nor deny to any person within its jurisdiction the equal protection of the laws."

While the creation of the Constitution of the United States and the Bill of Rights is often thought to provide protection of the rights of the United States people, those documents were written for the Federal Government and from the beginning of the creation of our great nation, the states challenged weather they had to follow these Federal documents when it was not to their liking. The Fourteenth Amendment provided a structure by which certain aspects of the Bill of Rights were to be applied to the states, a bridge of sorts. While the authors of the Fourteenth Amendment may have intended this bridge to be applied to the entire Bill of Rights, the battle between the Federal Government and States developed in a piece meal fashion that became known as the

\footnotetext{
40 “AP United States Government 2007-2008 Professional Development Materials. Special Focus: The Incorporation Doctrine.” The College Board. (2007), p.6. Retrieved from www.collegeboard.com.

${ }^{41}$ U.S. Constitution, amend. 14.
} 
selective incorporation doctrine. ${ }^{42}$ The Supreme Court weighed in on a case by case basis, deciding which elements of the Bill of Rights were to be applied to the states through the due process clause. Oddly enough, not all ten amendments of the Bill of Rights would be fully incorporated.

In essence, what this most often means to the off-campus internet speech cases is that students are bringing suit for violating a Bill of Rights freedom, most often speech, via the fourteenth amendment that makes it required that states also recognize that freedom.

The other Fourteenth Amendment violation that appears is a violation of a student's due process rights. The due process clause of the Fourteenth Amendment states simply that no, “...State shall deprive any person of life, liberty, or property without due process of law." ${ }^{43}$ Through the years the Supreme Court has come to recognize two types of due process in the interpretation and application of this amendment, substantive and procedural. Substantive due process is the more complex of the two and addresses those areas which the courts have found to lie outside of the scope of governments due powers. ${ }^{44}$ In essence, the government overstepped their bounds in even dealing with a certain issue.

Procedural due process is understood to mean that when the government takes action against a person that may adversely affect their right to life, liberty, or the pursuit of happiness, the government must follow certain established procedures. ${ }^{45}$ In terms of the off-campus internet speech cases, an example of this type of violation might be a parent

\footnotetext{
42 “AP United States Government 2007-2008 Professional Development Materials. Special Focus: The Incorporation Doctrine." The College Board. (2007), p.6. Retrieved from www.collegeboard.com.

${ }^{43}$ U.S. Constitution, amend. 14.

44 “AP United States Government 2007-2008 Professional Development Materials. Special Focus: The Incorporation Doctrine.” The College Board. (2007), p.12. Retrieved from www.collegeboard.com. 45 "AP United States Government 2007-2008 Professional Development Materials. Special Focus: The Incorporation Doctrine.” The College Board. (2007), p.12. Retrieved from www.collegeboard.com.
} 
making claim that the school did not hold a formal hearing regarding the matter before issuing discipline to the student. In most cases of short term discipline being issued, the standard discipline hearing with the student and school official is suffice to meet this aspect of due process. In cases where a student is facing a lengthy suspension or expulsion, a formal hearing is required.

\section{Goss v. Lopez}

The key case in dealing with students and the fourteenth amendment is Goss $v$. Lopez from 1975. ${ }^{46}$ Nine students in Ohio were suspended from high school or junior high for various acts of disruptive or disobedient conduct during a particularly volatile period of student unrest in the spring of 1971. Each student was suspended for up to 10 days without a hearing for his or her various roles in the unrest. The state of Ohio laws allowed for such suspensions at the time. The students sued claiming that the suspensions and the laws that supported them were unconstitutional and denied them of due process guaranteed by the $14^{\text {th }}$ amendment.

The Supreme Court ruled in favor of the students and found that they were indeed entitled to due process protection under the $14^{\text {th }}$ amendment. Students, like all other citizens, have a right to due process. The fact that misconduct charges can sully a person's reputation as well as jeopardize future employment and educational opportunities are grounds for the student's rights to due process. Schools may not, therefore, claim the right to determine unilaterally whether or not misconduct has occurred. This directly counters the whole idea of due process.

\footnotetext{
${ }^{46}$ Goss v. Lopez, 419 U.S. 565 (1975).
} 
The court further stated that a 10-day suspension is no minor occurrence and cannot be imposed while ignoring the right to due process. The Supreme Court decided that, “...students facing temporary suspension have interests qualifying for protection of the Due Process Clause, and due process requires, in connection with a suspension of 10 days or less, that the student be given oral or written notice of the charges against him and, if he denies them, an explanation of the evidence the authorities have and an opportunity to present his side of the story. The Clause requires at least these rudimentary precautions against unfair or mistaken findings of misconduct and arbitrary exclusion from school." ${ }^{47}$ In most cases, these events should take place before the student is removed from school.

The courts recognized that there would be times where the hearing could not occur prior to the student being removed from school. In instances where the student poses a threat to themselves or others, the student may be removed and a hearing scheduled for a soon as reasonably possible afterwards. The distinction was also made that longer suspensions or expulsions should have more formal requirements and hearings.

This case has bearing on school administrators today directly. In instances where information is found on cell phones or via the internet that a student is a danger to themselves or others, this case supports the schools in removing the student form the educational setting directly. It also serves as a protection for students that school administrators not seize information that may be misunderstood and unilaterally remove

\footnotetext{
${ }^{47}$ Goss v. Lopez, 419 U.S. 574 (1975).
} 
the student from school. It clarifies the ground rules for both school officials and students as to what the rights and responsibilities of each should be.

\section{Right to Privacy - Brandeis}

Americans see the right to privacy as a key right they hold today. A person's private life should be left private if the individual so desires. While this notion may seem like a fundamental right tied to the founding of our nation, the concept actually only came to fruition in the modern sense in the late 1800 's.

Louis Brandeis and Samuel Warren created the modern notion of privacy in their seminal article "The Right to Privacy" which was published in the Harvard Law Review in $1890 .^{48}$ Brandeis and Warren had been friends for about fifteen years, had gone to Harvard together, had graduated 1 and 2 in the class respectively, and had been law partners for ten years when the article was written. ${ }^{49}$ Samuel Warren came from a wealthy paper manufacturing family while Louis Brandeis was the son of Jewish immigrants of limited means. Warren asked Brandeis to help author the article in partial response to Warren's abhorrence of the way the sensational press of the day spread the intimate details of his wealthy family's home life on the pages of papers such as the Saturday Evening Gazette. ${ }^{50}$ The current notion of what exactly privacy entailed was created through this article and the related Olmstead v. United States case of 1928, which Louis Brandeis as a member of the Supreme Court wrote the dissenting opinion calling for support of privacy. ${ }^{51}$ It is somewhat ironic that while Brandeis is often remembered

\footnotetext{
${ }^{48}$ Warren, Samuel \& Louis Brandeis, "The Right to Privacy," The Harvard Law Review. Vol. IV (1890). Retrieved from: http://faculty.uml.edu/sgallagher/Brandeisprivacy.htm.

${ }^{49}$ Dorothy J. Glancy, "The Invention of the Right to Privacy," Arizona Law Review. Vol. 21:1 (1979), 4.

${ }^{50}$ Dorothy J. Glancy, "The Invention of the Right to Privacy," Arizona Law Review. Vol. 21:1 (1979), 5-6.

${ }^{51}$ Olmstead v. United States, 277 U.S. 438 (1928).
} 
for the Privacy article and the privacy-supporting dissent in Olmstead, he wrote many more decisions and seemed to be a champion for the cause of protecting free speech. ${ }^{52}$ While these two writings summarize the body of work by Brandeis on Privacy, he returned numerous times to the concept of free speech through publicity of information including articles in Harper's Magazine, a chapter on the idea in his book Other People's Money, and decisions in Supreme Court cases supporting free speech including Abrams v. United States, Schafer v. United States, Pierce v. United States, Gilbert v. Minnesota, the Milwaukee Leader case of 1921, Whitney v. California. ${ }^{53}$

In the article "The Right to Privacy" Warren and Brandeis argue that the founding fathers created a constitution to meet the needs of a changing world which the fathers themselves could not predict. "Political, social, and economic changes entail the recognition of new rights, and the common law, in its eternal youth, grows to meet the new demands of society." ${ }^{54}$ The problems they were addressing at the time were technological advances that included the telephone, the telegraph, portable and instant cameras, sound recording devices, and cheaper and more transparent window glass. ${ }^{55}$ While this was more than a century ago, it is interesting that advances in technology are causing similar problems, though in the form of electronic communications. The two young authors argued that the changing world required that laws change to protect people's right to privacy, or simply stated to be left alone. Warren and Brandeis rail

\footnotetext{
${ }^{52}$ Neil M. Richards, "The Puzzle of Brandeis, Privacy, and Speech," Vanderbilt Law Review, Vol. 63:5 (2010), 1313.

${ }^{53}$ Neil M. Richards, "The Puzzle of Brandeis, Privacy, and Speech," Vanderbilt Law Review, Vol. 63:5 (2010), 1322-1323.

${ }^{54}$ Samuel Warren \& Louis Brandeis, "The Right to Privacy," The Harvard Law Review. Vol. IV (1890), 1. Retrieved from: http://faculty.uml.edu/sgallagher/Brandeisprivacy.htm.

${ }^{55}$ Dorothy J. Glancy, "The Invention of the Right to Privacy," Arizona Law Review. Vol. 21:1 (1979), 7-8.
} 
against gossip and the fact that people were no longer treating it as wicked but rather demanding that the press provide it.

Warren and Brandeis argue that when a person creates or publishes an idea, it is only when they consent that such creations are shared with the public. They do differentiate between public life and private life. Those people that put themselves in the public eye, through industry or office or whatever means, willingly expose themselves to a loss of privacy. ${ }^{56}$ The new technologies radically changed the notion of a private life for the average person as photographs and instant news allowed for delivery of images and possibly ideas without the consent of the photographed. The law, in their opinion, should change so that it continues to protect property, whether physical or intellectual, as it always had protected personal property. This must be so because the injury that can be done from sharing ideas or actions that people do not want to know can be every bit as devastating as taking property that is rightfully their own. In essences, the changing times simply required a broadening of the concept of property to meet the realities of a more technologically advanced world. It should not matter to what extent the action causes injury, if privacy is recognized as a right entitled to protection.

Warren \& Brandeis summarize their position as follows:

"The design of the law must be to protect those persons with whose affairs the community has no legitimate concern, from being dragged into an undesirable and undesired publicity and to protect all persons, whatsoever their position or station, from having matters which they may properly prefer to keep private, made public against their will. It

\footnotetext{
${ }^{56}$ Samuel Warren \& Louis Brandeis, "The Right to Privacy," The Harvard Law Review. Vol. IV (1890), 4. Retrieved from: http://faculty.uml.edu/sgallagher/Brandeisprivacy.htm.
} 


\section{is the unwarranted invasion of individual privacy which is reprehended, and to be, so far as possible, prevented." 57}

The reason behind this new idea of privacy was to protect people from damage to their inner feelings and their personality through the publication of matters of no concern to the public which they would rather keep private. ${ }^{58}$

In terms of the technological issues schools face today, this article sets the standard for privacy that the rest of the public enjoys. It will be against this backdrop that the different rules that schools follow will be contrasted.

\section{Olmstead v. United States Dissent}

The case of Olmstead $v$. the United States was not about students nor schools. ${ }^{59}$

The case was a brought when the government tapped telephone lines of suspected prohibition bootleggers and spent five months gathering evidence against the men using those telephone lines. Olmstead and the other defendants argued that this amounted to an illegal search and seizure in violation of the Fourth Amendment. ${ }^{60}$ The government argued that this activity did not amount to any breech of search and seizure as had been historically accepted. ${ }^{61}$ In fact, the Supreme Court sided with the government in this particular instance and said they were within their rights to tap phone lines without a warrant. The important element of this case in regards to the current study, and individual freedoms, is the dissent written by Justice Louis Brandeis.

Brandeis pointed out in his dissent that the constitution was not created to meet single incidents that arose but rather to be an ever changing document to meet the needs

\footnotetext{
${ }^{57}$ Warren, Samuel \& Louis Brandeis, "The Right to Privacy," The Harvard Law Review. Vol. IV (1890), 9. Retrieved from: http://faculty.uml.edu/sgallagher/Brandeisprivacy.htm.

${ }^{58}$ Dorothy J. Glancy, "The Invention of the Right to Privacy," Arizona Law Review. Vol. 21:1 (1979), 17.

${ }^{59}$ Olmstead v. United States, 277 U.S. 438 (1928).

${ }^{60}$ Olmstead v. United States, 277 U.S. 456 (1928).

${ }^{61}$ Olmstead v. United States, 277 U.S. 457 (1928).
} 
of the ever changing country that it supports. He states, "When the Fourth and Fifth Amendments were adopted, 'the form that evil had theretofore taken' had been necessarily simple. Force and violence were then the only means known to man by which a Government could directly affect self-incrimination....but time works changes, brings into existence new conditions and purposes, subtler and more far reaching means of invading privacy.",62

It was essential in the eyes of Brandeis that the court should not rely on a strict interpretation of what entails a possession to be protected as private, but rather change to meet the new demands of the new technological world, including limiting the use of wiretaps. The dissent would lead to the modern notion of privacy as being more than physical possessions in someone's residence. It is interesting to note that the issue in 1928 that was causing such angst was technology and how to deal with it. It is the same issue being dealt with by school administrators today.

\section{Current Legal Analysis}

The issue of off-campus speech that makes its way onto campus is a murky legal landscape. The lower level federal courts have come down on both sides of the argument, with the $3^{\text {rd }}$ district even rendering an opinion on each side in similar cases on the same day. The Supreme Court as recently as 2012 has had the opportunity to step in and hear such cases but has elected to stay out of the fray. The lower Federal Courts are left to their own discretion and apply one of the above cases to each new off-campus speech case depending upon their own inclination and the specific facts of the case, but with little consistency across the system. The law journals and dissertations written on

\footnotetext{
${ }^{62}$ Olmstead v. United States, 277 U.S. 473 (1928).
} 
the subject do little to clarify the situation as they are often written from the author's viewpoint of what should be, could be, or ought to be instead of as a guide to what actually is the situation. Titles such as "Poison Pens, Intimidating Icons, and Worrisome Websites: Off-Campus Student Speech That Challenges Both Campus Safety and First Amendment Jurisprudence,” and, "Tinker at a Breaking Point: Why the Specter of Cyberbullying Cannot Excuse Impermissible Public School Regulation of Off-Campus Student Speech," reveal as much about each authors bias as they do about the importance of the topic.

The examination of the legal journals and educational dissertations reveal a number of similarities shared by scholars in regards to the issue at hand. The most common theme to emerge is that all of the documents suggest the Supreme Court could clarify the situation rather quickly as opposed to allowing the lower level courts stumble over the issue of off-campus speech that makes its way on campus. ${ }^{63}$ There is also agreement that active administrators need some guidance in how to handle these cases utilizing best practice. Similarly, all of the research provides a summary of how the courts have decided various cases by applying some variation of the standards set forth in the case of Tinker v. Des Moines Independent Community School District. The result is a listing of how courts have made decisions and applied the standard of Tinker to this new breed of cases. The following legal journals provide examples of the facts and arguments being put forth.

\footnotetext{
${ }^{63}$ See Kathryn Vander Brock, Steven Puiszis, and Evan Brown, (2009); Samantha Levin, (2011); Nancy Gibbs, (2010); Nancy Willard, (2011); Douglas E. Abrams, (2011); Tova Wolking, (2008); and Thomas Wheeler, (2011).
} 
Vander Broek, Puiszis, and Brown wrote an article entitled, "Schools and Social Media: First Amendment Issues Arising From Student Use of the Internet." ${ }^{64}$ In the article the authors examine the issue of off-campus student speech that makes its way into the schoolyard in a formulaic manner. They present a brief legal history of speech not generally protected by the First Amendment before delving into student speech. The examination of student speech jurisprudence they present centers on the three cornerstone cases of Tinker v. Des Moines, Bethel v. Fraser, and Hazelwood v. Kuhlmeier. This article also makes the connection to Morse v. Frederick creating a big four so to speak. ${ }^{65}$ The authors argue that these cases simply do not provide enough guidance to the lower courts, which interpret and apply them differently as off-campus speech does not exactly fit the criteria set forth by the cases. Vander Broeck et al. take the approach of summarizing the commonalities found in current cases. They note that, "...internetbased, off-campus student speech is an evolving are of First Amendment law producing decisions that are highly fact-specific." ${ }^{66}$ They do offer a number of commonalities that lower courts demonstrated in upholding student discipline and finding in favor of the schools. The commonalities include schools demonstrating a true threat was made, proving the website was viewed at school, use of school computers in the event, reacting to more outrageous or potentially dangerous speech, discipline focused on extracurricular activities, and the younger the student the greater the schools leeway in

\footnotetext{
${ }^{64}$ Kathryn S. Vander Broek, Steven M. Puiszis, and Evan D. Brown. "Schools and Social Media: First Amendment Issues Arising From Student Use of the Internet." Intellectual Property \& Technology Law Journal.Vol. 21:4 (April 2009): 11-27. Business Source Premier, EBSCOhost (accessed July 1, 2012).

${ }^{65}$ Ibid, p.14.

${ }^{66}$ Ibid, p.16.
} 
discretion. ${ }^{67}$ While these suggestions for strengthening a case are useful, they do not truly address those cases where the speech clearly originates outside of school and the school issues discipline for some reason or another. The review further moves away from the issue in examining on-campus speech such as shirts and employee speech before offering policy suggestions to strengthen school authority in addressing issues that later could be issued discipline, which seem to be of at least a medium level of importance in this particular topic for administrators. In terms of bias, this article clearly seems to be advocating for increased school authority to intervene and provides specific examples of how schools can strengthen their position in case they do end up in court.

Samantha Levin, writing in the Fordham Urban Law Journal during 2011 authored an article titled, "School Districts As Weatherman: The School's Ability to Reasonably Forecast Substantial Disruption To The School Environment From Students' Online Speech". ${ }^{68}$ Levin also reviews the Supreme Court jurisprudence on student speech including Tinker, Fraser, and Morse but decides not to touch on Hazelwood. She also uses the article to suggest a new standard by which the courts should judge these cases by instead of Tinker. Her suggestion is to eliminate completely the first prong of Tinker that looks at if the speech is on or off campus and, “...concentrating instead on the impact of the online speech...by incorporating the factors of whether the likelihood of disruption is high and whether the type of disruption poses severe harm to the school environment." ${ }^{\prime 69}$ The suggestion seems more appropriate in dealing with the location of

\footnotetext{
${ }^{67}$ Ibid, p.16.

${ }^{68}$ Samantha M. Levin. "'School Districts As Weatherman: The School's Ability to Reasonably Forecast Substantial Disruption To The School Environment From Students' Online Speech." Fordham Urban Law Journal. Vol. 38, no. 3 (March 2011): 859-897. Academic Search Complete, EBSCOhost (accessed July 1, 2012).

${ }^{69}$ Ibid, p.862.
} 
internet speech as the author points out, "...once courts are able to understand the boundary-less location of the internet, the applicability of Tinker becomes more comprehensible."70 There does seem to be a problem with the second portion of the standard proposed in that the harm caused by cyber-bullying would have to be weighed by the reasonableness that the bullying comments or threats would actually be carried out. This is simply unacceptable in a public school where children are entrusted to the administration to receive an education in a safe setting. The author goes so far as to suggest that under her new standard, a student who were to post on their social network page that they were going to kill everyone in the school could not be disciplined because while the harm is high, the probability of a student actually carrying out such an act is low. ${ }^{71}$ This is student speech protection taken to the extreme. It also ignores the impact that cyber bullying may have on young people. The highly publicized case of Phoebe Prince is an example of how deep the impact of bullying can be on a student. Prince was the Boston area student who committed suicide after months of bullying. Her parents filed suit against the students and the school, in addition to criminal charges being filed. ${ }^{72}$

Nancy Willard also addressed the issue of online speech in her article "School Response To Cyberbullying and Sexting: The Legal Challenges" that appeared in the January 2011 edition of the B.Y.U. Education and Law Journal. While Willard focuses in on cyber bullying and sexting specifically, the issue of off-campus internet speech is covered. Willard presents an argument on the harms of bullying and cyber bullying before examining the Supreme Court jurisprudence including the cases of Tinker, Bethel

\footnotetext{
${ }^{70}$ Ibid, p.868.

${ }^{71}$ Ibid, p.892.

72 Nancy Gibbs. "When Bullying Goes Criminal." Time(online edition). April 19, 2010.
} 
School District 403 v. Fraser, and Hazelwood School District v. Kuhlmeier. ${ }^{73}$ Willard then examines some of the more recent cases and examines the outcomes for off-campus internet speech cases before making suggestions for schools to follow. ${ }^{74}$ The suggestions really amount to a summation of the Tinker standard and includes bullet points such as drawing a school nexus, documenting an impact at school, reasonably predicting an impact at school, and documenting the impact is material and substantial. ${ }^{75}$

Willard then moves in a slightly different direction from the other journals in looking at off-campus speech and personal digital devices. This angle is unique and appears to be appropriate in addressing as more and more students, and at younger ages, have access to such devices and utilize them at continuing higher degrees. Even with the digital devices, the rationale for disciplining students goes back to the three main cases of Tinker, Fraser, and Hazelwood according to Willard. ${ }^{76}$ The nature of personal digital devices also elicits a discussion of search and seizure precedent as the device in question usually belongs to the student. This wrinkle is also pertinent to the off-campus speech cases when that off-campus speech is brought to school via personal digital devices. As the prevalence of personal digital devices continues to increase, the intermingling of the issues of free speech and student searches are also likely to continue.

Willard concludes with an examination of hostile environment cases which may not be directly related to the off-campus speech issue and beyond the scope of this proposed study.

\footnotetext{
${ }^{73}$ Nancy Willard. "School Response to Cyberbullying and Sexting: The Legal Challenges." Brigham Young University Education \& Law Journal. No. 1 (January 2011): 75-125. MasterFILE Premier, EBSCOhost (accessed June 28, 2012).

${ }^{74}$ Ibid, p. 108 .

${ }^{75}$ Ibid, p. 108 .

${ }^{76}$ Ibid, p. 109 .
} 
Douglas E. Abrams writing in the New England Journal on Criminal and Civil Confinement addressed the issue with his article "Recognizing the Public Schools' Authority to Discipline Students' Off-Campus Cyberbullying of Classmates." ${ }^{17}$ Abrams also examines non-protected speech under the first amendment, Tinker and like student speech cases, and the application of the Tinker standard to student speech. Abrams also examined the jurisprudence of Fourth Amendment student issues as an off-shoot of Tinker and a necessity in the technological landscape surrounding cyber bullying. ${ }^{78}$ Abrams takes the investigation a step further and draws in the issue of privacy in the technological era by examining how the case of Olmstead $v$. United States should also be considered. ${ }^{79}$ The case of Olmstead was brought in regards to the government tapping telephone lines without a warrant in the 1920s. ${ }^{80}$ Justice Louis Brandeis, writing in dissent, noted that the limited scope of previous fourth amendment concepts of search and seizure were not suffice for the technological issues of the day. He ultimately argued that for the law to be effective, it must be allowed to have a broader application than the narrow situation that gave it birth. ${ }^{81}$ Justice Brandeis sounds as on point now as he was then in pointing out that it really does not matter if the physical connection (wire-tapping then and internet posting today) actually occurred because technology changes over time. $^{82}$

\footnotetext{
${ }^{77}$ Douglas E. Abrams. "'Recognizing the Public Schools' Authority to Discipline Students' Off-Campus Cyberbullying of Classmates." New England Journal on Criminal and Civil Confinement. Vol. 37, (Spring 2011):181-225. LexisNexis Academic: Law Reviews, EBSCOhost (accessed June 27, 2012).

${ }^{78}$ Ibid, p. 200.

${ }^{79}$ Olmstead v. United States, 277 U.S. 438 (1928).

${ }^{80}$ Olmstead v. United States, 277 U.S. 438 (1928).

${ }^{81}$ Ibid, 472-3.

${ }^{82}$ Ibid, $472,479$.
} 
The Berkeley Technology Law Journal published an article in the October 1, 2008 edition titled "School Administrators as Cyber Censors: Cyber Speech and First Amendment Rights." ${ }^{83}$ As with the other law review articles, Tova Wolking examines the Supreme Court Jurisprudence including Tinker, Fraser, Kuhlmeier, and Morse. The author then moves into the cyber speech cases and looks at a handful of cases that were heard prior to 2008 by lower courts to examine how free speech cases were decided.

Wolking provides two graphics which are termed "frameworks" which are in the right vein to aid practicing administrators. ${ }^{84}$ The first framework is really just a listing of general non-protected first amendment speech which is the first prong, or prior to the first prong, of the Tinker Standard. ${ }^{85}$ The second framework is a graphic representation of the Tinker Standards two prong test. ${ }^{86}$ While the particular graphics are summarizations of current jurisprudence, the concept of a graphic, flow chart, or series of questions that an administrator could reference in dealing with such issues is a valuable one.

Another of the summary law review articles appeared in the Winter 2011 edition of the Pace Law Review. Thomas Wheeler authored a piece entitled, "Facebook Fatalities: Students, Social Networking, and the First Amendment." ${ }^{87}$ This article also summarized the Supreme Court jurisprudence on student speech including Tinker, Fraser, Kuhlmeier, and Morse. This article differed in that it provided some specific area that the schools need clarification from the Supreme Court. While pointing out that,

\footnotetext{
${ }^{83}$ Tova Wolking. "School Administrators as Cyber Censors: Cyber Speech and First Amendment Rights." Berkeley Technology Law Journal. Vol. 23, (October 1, 2008): 1507-1530. LexisNexis Academic: Law Reviews, EBSCOhost (accessed June 27, 2012).

${ }^{84}$ Ibid, p. 1513, 1524.

${ }^{85}$ Ibid, p. 1513.

${ }^{86}$ Ibid, p. 1524.

${ }^{87}$ Thomas Wheeler. "Facebook Fatalities: Students, Social Networking, and the First Amendment." Pace Law Review 31, no. 1 (January 2011): 182-227. Academic Search Complete, EBSCOhost (accessed June $28,2012)$.
} 
"...when you have two panels of learned jurists releasing contrary opinions on similar facts on the same day, there is an obvious need for clarity." ${ }^{18}$ This response was in reference to the Third Circuits opposing decisions on two internet speech cases with similar details. Recognizing this need, Wheeler offered that specifically, the schools need clarification in terms of what exactly constitutes on-campus speech, when does the reasonably foreseeable disruption element of the Tinker standard apply, and is there a more appropriate standard to apply to the subset of cyber-bullying. ${ }^{89}$ This is substantially different from the other articles in that it offers specific flaws in the current framework that administrators encounter in trying to apply the Tinker Standard. The author points out that, "...the tools available to school administrators to deal with such speech are not yet fully formed...," but deal with the issues they must. ${ }^{90}$

An article from the pro-speech side of the debate comes from the March 2011 Brigham Young University Law Review. Allison Belnap wrote a piece titled, "Tinker at a Breaking Point: Why the Specter of Cyberbullying Cannot Excuse Impermissible School Regulation of Off-Campus Student Speech."11 The author begins by recognizing the student suicide cases due to cyber bullying that have made headlines in recent years including Phoebe Prince, Ryan Hulligan, Megan Meier, and Tyler Clementi. ${ }^{92}$ While recognizing the tragedy that each of these cases represent, the author argues that allowing schools free reign to legislate off-campus speech in their name is a colossal mistake.

\footnotetext{
${ }^{88}$ Ibid, p. 213.

${ }^{89}$ Ibid, p. 214.

${ }^{90}$ Ibid, p. 227.

${ }^{91}$ Belnap, Allison. "Tinker at a Breaking Point: Why the Specter of Cyberbullying Cannot Excuse Impermissible Public School Regulation of Off-Campus Student Speech." Brigham Young University Law Review 2011. No. 2 (March 2011): 501-533. Academic Search Complete, EBSCOhost (accessed July 2, 2012).

${ }^{92}$ Ibid, p. 501.
} 
There are four areas that school administrators should never be allowed to tread, including speech originating and concluding wholly outside the physical school boundaries, speech that is neither created nor propagated at a school event, speech that is facilitated with devices not school owned, and speech that does not materially and substantially interfere with the requirements of appropriate discipline in the operation of the school. ${ }^{93}$ The author, like the other authors, examines the jurisprudence of school speech cases including Tinker, Fraser, and Kuhlmeier. The vehicle for arguing that schools should not be able to regulate off-campus speech is an analysis of the two cases that the Third Circuit rendered a split decision on which were Layshock v. Hermitage School District and J.S. ex rel Snyder v. Blue Mountain School District. ${ }^{94}$ The standard that the author argues for is akin to a "true threat" standard, which the First Amendment does not protect. This principal concept is that for speech of a threatening nature to be disciplined, the school would need to prove that a true threat of the action being carried out would need to exist. "The school may rely on the victim's subjective fear of violence, but must also consider the context in which the expression was offered as well as the reaction of the audience to the expression." 95 This seems to completely ignore the unique characteristics of schools and the sensitive and less than developed psyches of those students who attend them. If students were able to simply sift out what is not truly meant from what is, there would not be a need for cyber bullying legislation and policy.

One article that squarely lands in the school authority camp is, "Poison Pens, Intimidating Icons, and Worrisome Websites: Off-Campus Student Speech that

\footnotetext{
${ }^{93}$ Ibid, p. 504.

${ }^{94}$ Ibid, p. 517.

${ }^{95}$ Ibid, p. 530.
} 
Challenges both Campus Safety and First Amendment Jurisprudence. ${ }^{196}$ This article also examines student speech jurisprudence and includes Tinker, Fraser, Kuhlmeier, and Morse. The author argues however that there is no place for threatening speech at schools and they are in fact the best vehicle for addressing such speech. ${ }^{97}$ While the criminal justice system has a much higher standard for determining a true threat, schools unique position in providing a safe learning environment for all allows them the latitude to act quickly in that interest and deal with issues that threaten that safety. ${ }^{98}$ The author further argues that school discipline could potentially be more appropriate than criminal action, especially in those cases that are found to be intended as a joke or simply acting out. Likewise, the failure of a school to act in such a case that is thought to be a joke and is actually carried out could be catastrophic. ${ }^{99}$ In short, the protection of the many students outweighs the free speech rights, at least with threatening speech whether true or not, of the individual in the eyes of the author.

There are dissertations on the topic of off-campus student internet speech that results in discipline from the schools as well. David Bowlin wrote his dissertation in 2004 at the University of Pittsburgh titled, "Cyberspace Off-Campus Student Rights': A Legal Frontier for School Administrators." ${ }^{100}$ Bowlin examined First Amendment jurisprudence on student speech as well as the cases at the state and lower Federal levels prior to 2004. He pointed out that administrators needed descriptive guidelines for

\footnotetext{
${ }^{96}$ Garcia, Kathy Luttrell. "Poison Pens, Intimidating Icons, and Worrisome Websites: Off-Campus Student Speech That Challenges Both Campus Safety and First Amendment Jurisprudence." St. Thomas Law Review. Vol. 23, no. 1 (October 2010): 52-90. Academic Search Complete, EBSCOhost (accessed July 3, 2012).

${ }^{97}$ Ibid, p. 70.

${ }^{98}$ Ibid, p. 71.

${ }^{99}$ Ibid, p. 72.

${ }^{100}$ David Bowlin. Cyberspace Off-Campus Student Rights A Legal Frontier for School Administrators. University of Pittsburgh, 2004.
} 
dealing with such cases and offered what he called a Reasonable Forecast Tool to that end. ${ }^{101}$ The concept of a Reasonable Forecast Tool is on point and practical for practicing administrators and could be expanded on. The tool presented herein was really a rehashing of the Tinker Standard alone however. Additionally, he addressed the issue of internet speech policy guidelines for schools, which really amount to acceptable usage policy of school computers. This would be of help to administrators in those cases where student speech is generated off-campus, but school technology is used to view or disseminate the speech. This study did not examine any cases where the speech was not accessed at school or accessed using school technology. Cases have come before the courts where the speech intrudes on the school but was not necessarily accessed utilizing school technology. Again, the traditional geographic boundaries that separate school from are no longer black and white.

Jesulon Sharita Ronae Gibbs wrote her dissertation at Indiana University in 2008 on "The First Amendment and Modern Schools: A Legal Analysis of Off-Campus Student Speech Cases." ${ }^{102}$ Gibbs also examined First Amendment jurisprudence as well as state and federal lower court findings on the topic prior to 2008. Gibbs utilizes a matrix for examining the cases that examine the nexus to the school, standard applied, prevailing party and rationale of the various courts. This allows for the reader to quickly and effectively follow the cases and rationale used to determine them. This is a worthwhile tool to be considered in such an examination. The author further goes on to present a basic flowchart for administrators to determine the appropriateness of issuing

\footnotetext{
${ }^{101}$ Ibid, p. 27.

102 Jesulon Sharita Ronae Gibbs. "The First Amendment and Modern Schools: A Legal Analysis of OffCampus Student Speech Cases." Indiana University, (2008).
} 
discipline for off-campus speech. This chart could be expanded on to provide a more robust reference for administrators to utilize, including the more recent cases to reach the Federal Courts. The proposed study will examine only cases that have reached the Federal level building on Gibbs's matrix concept. the proposed study also will provide a more thorough reference tool to aid administrators in applying the current court cases in dealing with off campus student speech that makes its way into the schoolyard.

Joe Dryden authored a dissertation at the University of North Texas titled, "School Authority Over Off-Campus Student Expression in the Electronic Age: Finding a Balance Between a Student's Constitutional Right to Free Speech and the Interest of Schools in Protecting School Personnel and Other Students From Cyber-Bullying, Defamation, and Abuse." ${ }^{103}$ Dryden also explores First Amendment jurisprudence and the recent issue of off-campus speech that makes its way on campus resulting in discipline. The author also utilizes a matrix to explore these newer cases and divides them into cases that support students and cases that support schools. He further examines the various standards applied by the lower courts in deciding the cases. His recommendations come in the form of laying out the various different approaches that have been utilized by the lower level courts and offered by commentators on various sides of the issue. He also attempts to predict what the Supreme Court might decide should they take up the split decision of the Third Circuit (which they ultimately decided against hearing).

\footnotetext{
${ }^{103}$ Joe Dryden. "School Authority Over Off-Campus Student Expression in the Electronic Age: Finding a Balance Between a Student's Constitutional Right to Free Speech and the Interest of Schools in Protecting School Personnel and Other Students From Cyber-Bullying, Defamation, and Abuse." University of North Texas (2010).
} 
A look at the previous research in total shows some interesting trends. There appear to be four broad categories of writing on the topic. The four categories consist of a summary of cases for awareness sake, policy suggestion, pro-speech agenda, and call for action from the Supreme Court. The summary writings are those that examine the cases that have reached the courts and the outcomes of those cases. These writings are sometimes done for the sake of awareness of the issue or for sometimes in the context of examining several school issues to consider. Policy suggestion papers utilize the court cases to make an argument why particular policy, such as an internet usage policy, is necessary or specific elements to include in creating such a policy. The pro-speech writings examine the cases from the viewpoint of protecting the first amendment for all people, including students. These writings may just call for such protection or may suggest different standards that courts should utilize in place of Tinker in judging such cases. The final category are writings on the topic address specific shortcomings that the current situation leaves for administrators and calls on the courts, often the Supreme Court, to address those specific shortcomings. The writings generally fall into these four categories dependent upon the rationale for writing each.

The proposed study will begin by building upon the concept of having a chart or matrix that summarizes Federal Jurisprudence on student speech and off campus internet speech. The additional information to be included would be a rationale segment referencing the previous cases or concepts the courts accessed in deciding such cases. Understanding why the courts have arrived at the various decisions that they have will be important information for administrators to consider when dealing with off campus student speech that makes its way on campus. That is the second element to be examined 
within the proposed study. A current reference tool for practicing administrators that is more complete than models currently in existence. 


\section{CHAPTER III}

\section{SUPREME COURT JURISPRUDENCE ON STUDENT SPEECH}

\section{In Loco Parentis}

In American education, in loco parentis has loosely meant in place of the parent. The idea as applied in education can be traced back to Sir William Blackstone in 1765 when he wrote that the father may delegate part of his parental authority to the tutor or

schoolmaster of his child. ${ }^{104}$ It is believed this was done as a legal defense for educators accused of student battery. It may be assumed that the concept was imported to the United States from England as both defense of and justification for corporal punishment of students.

The case of the State v. Prendergast went before the North Carolina Supreme Court in $1837 .{ }^{105}$ It is the Prendergast case that first supports the concept that the teacher is the substitute of the parent. ${ }^{106}$ This would be the basis from which the school system would operate until challenged in court on various specific counts.

This idea is clearly applicable to technologically related discipline issues in schools today as the concept has lost such clear support. Schools are now expected to act much more like a government agency than like a parent of a student. While schools are

\footnotetext{
${ }^{104}$ Edwards, Alan. (1994). In loco parentis: Alive and kicking, dead and buried, or rising phoenix? ASHE annual meeting paper. Retrieved from: http://www.eric.ed.gov/PDFS/ED375720.pdf

${ }^{105}$ State v. Prendergast, 19 N.C. 365 (1837).

${ }^{106}$ Ibid.
} 
afforded more latitude than police in dealing with children, they are certainly not allowed the full range of freedoms that a parent has over their child.

\section{First Amendment Cases}

The following cases provide the specific details of how the courts have arrived at the decision of what is protected speech and what is not. These cases provide the lens through which the courts examine cases that come before them today. The concept will come back into play as we examine the current technological issues that school officials deal with. The courts have decided through the years that the balance between students' rights to free speech and the school responsibility to educate all children in an orderly manner must be balanced.

The case of Burnside v. Byars in 1966 is the first to utilize key language regarding the disruption of the school day as a reason for disciplinary action. ${ }^{107}$ A group of public school students at an all-black school in Philadelphia, Mississippi wore freedom buttons to protest racial segregation in the state. The school principal ordered the students to remove the buttons because he believed the buttons would cause a commotion and disturb the school day. When several students continued wearing the buttons the principal suspended them for a week. The students filed suit.

The fifth circuit court sided with the students and stated that schools could not suspend students or ban ideas or discussion arbitrarily because it makes them uncomfortable. Judge Walter Gewin pointed out, "But with all this in mind we must also emphasize that school officials cannot ignore expressions of feelings with which they do not wish to contend. They cannot infringe on their students' right to free and unrestricted

${ }^{107}$ Burnside v. Byars, 363 F.2d 744 (1966). 
expression as guaranteed to them under the First Amendment to the Constitution, where the exercise of such rights in the school buildings and schoolrooms do not materially and substantially interfere with the requirements of appropriate discipline in the operation of the school.",108

The Burnside v. Byars Circuit Court decision actually provides the language which the more famous Tinker $v$. Des Moines case draws from. In our current technological age, the burden of proof in upholding a student suspension often will be measured against this very language. Those schools that demonstrate a reasonable expectation of "material and substantial disruption" to the school day are more likely to have their discipline upheld when challenged in court. Those schools that do not show a reasonable expectation of such a disturbance, will often be on the losing end of the judgment. This standard is applied to both freedom of expression issues and search and seizure issues.

The case of Tinker v. Des Moines Independent Community School District in 1969 is most commonly associated with first amendment freedom of expression issues. ${ }^{109}$ Two high school students and a junior high student, with the consent of their parents, decided to wear black arm bands to protest the hostilities in Vietnam. The building principals became aware of the intention to wear the armbands and adopted a policy on December $14^{\text {th }}$ that any student wearing an armband would be asked to remove it. Any student refusing to remove the armband would be suspended until they returned without the armband. The students were made aware of the newly adopted policy prior to the scheduled day they set to wear the armbands. The three students wore armbands over the

\footnotetext{
${ }^{108}$ Burnside v. Byars, 363 F. 2d 749 (1966).

${ }^{109}$ Tinker v. Des Moines Independent Community School District, 393 U.S. 503 (1969).
} 
course of December $15^{\text {th }}$ and $16^{\text {th }}$ and were all sent home and suspended. A total of five students were suspended and sent home for the armbands out of a student body of 18,000. The students did not return to school until after the winter break.

The Supreme Court ruled in favor of the students and saw the school action as a suppression of first amendment rights. The Supreme Court actually referred to the earlier case of Burnside v. Byars in 1966 stating that wearing of armbands and like symbols cannot be band unless it, "...materially and substantially interferes with the requirements of appropriate discipline in the operation of the school." 110 The Supreme Court also cited the Burnside case in pointing out school officials cannot ban expressions of feelings that they simply do not want to deal with.

This case provides a standard by which both freedom of speech issues and student search issues are measured. Some of the recent cell phone related cases and the internet posting related cases refer back to the exact language made famous here in looking for proof of a, “...material and substantial interference of the requirements of appropriate discipline in the operation of the school." 111 This is a seminal case in examining current issues in student search and discipline in our technological era. This language will be present in all cases claiming a disruption to the school day as the reason for discipline.

The case of Watts $v$. United States in 1969 was the first true threat case to reach the Supreme Court. ${ }^{12}$ While this is not a student speech case specifically, it has been referenced in deciding online speech cases involving students. The case was brought when Robert Watts was convicted of violating a Federal Statute when he made a threat to

\footnotetext{
${ }^{110}$ Tinker v. Des Moines Independent Community School District, 393 U.S. 510 (1969).

${ }^{111}$ Burnside v. Byars, 363 F. 2d 749 (1966).

${ }^{112}$ Watts v. United States, 394 U.S. 705 (1969).
} 
shoot the President. Watts was involved in a protest against the Vietnam War when he spoke to a group and stated, "I am not going. If they ever make me carry a rifle the first man I want to get in my sights is LBJ."113 The court ultimately found Watts' speech was not a true threat but rather political speech and therefore he did not actually threaten the life of president Johnson. "Taken in context, and regarding the expressly conditional nature of the statement and the reaction of the listeners, we do not see how it could be interpreted otherwise."114 While this case provided the concept that a threat must be deemed a "true threat" to address the speech, it does not give clear guidelines as to what a true threat actually is. The three elements this case does provide is speech of a political nature, the context of the speech, and if the speech is of a conditional nature. In terms of student speech, the true threat standard will still surface. When language is found to be a true threat involving a student, the matter may include a criminal investigation in addition to or in place of school discipline depending upon the situation. The current technological age has made it more challenging as the student of fifty years ago who might mutter something under his breath about wanting to kill someone out of anger, now might post that utterance on the internet and suffer severe consequences for it even if it was a comment made out of frustration with no real intention to carry out the act.

The "true threat" doctrine became a little more defined in 2003 with the Virginia v. Black ruling by the Supreme Court. Three men in separate incidents were convicted of burning crosses which was in and of itself prohibited by a Virginia statute because it is intimidating in nature. Sandra Day O'Connor wrote for the majority, “...true threats encompass those statements where the speaker means to communicate a serious

\footnotetext{
${ }^{113}$ Watts v. United States, 394 U.S. 706 (1969).

${ }^{114}$ Watts v. United States, 394 U.S. 705 (1969), p.3.
} 
expression of an intent to commit an act of unlawful violence to a particular individual or group of individuals. The speaker need not actually intend to carry out the threat."115 Justice O'Connor further explained that, “...intimidation in the constitutionally proscribable sense of the word is a type of true threat, where a speaker directs a threat to a person or group of persons with the intent of placing the victim in fear of bodily harm or death." not necessarily needed according to the Supreme Court, and it is classified as a nonprotected form of speech that could ultimately be a crime. This makes a difference in how school administrators potentially handle true threat incidents. The notion that the speaker intended to carry out the threat is less important than the speaker believing they were in danger of the threat being carried out.

The case of Bethel School District 403 v. Fraser addressed the issue of school authority over student speech at school-sponsored events. ${ }^{117}$ A high school student gave a speech nominating a friend for a student elective office. The speech was delivered to approximately 600 students, many of whom were 14 years old. The speaker referred to the candidate in terms of an elaborate, graphic, and sexual metaphor throughout the entirety of his speech. The audience responses varied from yelling and acting out the sexual metaphor to confusion and embarrassment. The speaker discussed his intention with several teachers prior to giving the speech, two of which suggested he not give it. The day after the speech, the Assistant Principal called the student in and informed him that she found the speech in violation of the school's disruptive conduct rule which

\footnotetext{
${ }^{115}$ Virginia v. Black, 538 U.S. 344 (2003).

${ }^{116}$ Virginia v. Black, 538 U.S. 345 (2003).

${ }^{117}$ Bethel School District 403 v. Fraser, 478 U.S. 675 (1986).
} 
prohibited any disruptive behavior that interfered with the educational process including obscene or profane language or gestures. The student was given copies of the teacher's reports about the speech and given a chance to explain himself. He admitted that he used sexual innuendo and was informed he would be suspended for three days and his name would be removed from the list of potential graduation speakers. The student appealed through the school discipline process but the discipline was upheld. The student and his father then filed suit on grounds of first amendment violations and that his due process rights were violated as he did not realize the speech would result in suspension do to the vague wording of the school policy.

The Supreme Court sided with the school in this case. The First Amendment does not prevent schools from disciplining students for lewd and indecent speech. Students do not have the same political protection that the first amendment affords adults as it is, “...a highly appropriate function of public school education to prohibit the use of vulgar and offensive terms in public discourse." 118 The decision of what is inappropriate for students ultimately rests with the board of education.

The Courts also found that there was no fourteenth amendment due process violation. The court held that school's needed to be able to discipline for a wide range and unanticipated range of conduct that may interrupt the educational process and, therefore, “....school disciplinary rules need not be as detailed as a criminal code which imposes criminal sanctions." 119

This impact of the Bethel case on schools in the technological era is two-fold. The first impact is that the Courts have confirmed the schools ability to determine the

${ }^{118}$ Bethel School District 403 v. Fraser, 478 U.S. 683 (1986).

${ }^{119}$ Bethel School District 403 v. Fraser, 478 U.S. 686 (1986). 
definition of obscenity at school and school sponsored events. As students bring technology such as cell phones with them to school, schools can determine if the content of those phones is inappropriate if it is out.

This case also allows schools to deal with the changing technological landscape without addressing details that may be outdated in a short amount of time by recognizing that schools have to deal with unanticipated actions and must be allowed the latitude to protect the educational environment through more general disciplinary rules. This prevents schools from having to create language or policy for every technological change that occurs, which is daily if not hourly in our modern world.

The Hazelwood School District v. Kuhlmeier case was instrumental in determining what a school may censor and what it may not within the scope of the educational curriculum. ${ }^{120}$ The Hazelwood High School newspaper was written and edited by the journalism class as part of the school's curriculum. The teacher for the class would routinely submit the proposed paper to the principal for approval before sending the paper to press. In the case in question, the student staff was planning on running two articles that the principal found objectionable. The first article described students' experience with pregnancy and the second examined the impact of divorce on students. The principal objected to the pregnancy article because he feared that the students could be identified from the article even though they were not mentioned by name and because he felt the references to sex and birth control were not appropriate for younger students. The divorce article he found objectionable because the student, who appeared by name, made disparaging comments against her father, and the principal felt

${ }^{120}$ Hazelwood School District v. Kuhlmeier, 484 U.S. 260, (1988). 
the father should have the opportunity to respond to the comments or give consent for the publication of the article. The principal decided to pull the entire two pages that contained the articles because he believe there was not time to rewrite the articles and meet the deadline for publishing the paper. The student staff members filed suit believing that their first amendment rights were violated.

The Supreme Court decided that the students' first amendment rights were not violated. There were three reasons that the Supreme Court gave for believing that the principal acted reasonably. The first reason that the Supreme Court gave was that, “...schools are not required to tolerate speech that is inconsistent with its basic educational mission, even though the government could not censor similar speech outside of school.",121

The second reason the Supreme Court gave for the principal's being justified was that a student newspaper cannot be deemed to be a public forum for public expression. School facilities can be deemed to be public forums only if school authorities, by policy or practice, make them available to the public for indiscriminate use. The Supreme Court further stated that, “...school officials may impose reasonable restrictions on the speech of students, teachers, and other members of the school community..." if it is consistent with the newspaper's production as part of the educational curriculum. ${ }^{122}$ In short, this was an assignment and the articles were not appropriate for the assignment. This was not an open forum for discussion of beliefs.

The third point that the Supreme Court made through this case is that there is a difference between a school punishing a student for student expression on school grounds

\footnotetext{
${ }^{121}$ Hazelwood School District v. Kuhlmeier, 484 U.S. 261, (1988).

${ }^{122}$ Hazelwood School District v. Kuhlmeier, 484 U.S. 262 (1988).
} 
and a school refusing to lend its name and resources to the dissemination of student expression. In this case the Supreme Court ruled that the school was justified in, “...exercising editorial control over the style and content of student speech in schoolsponsored expressive activities, so long as their actions are reasonably related to legitimate pedagogical concerns."123

This case is important in light of our current technological era. The Supreme Court pointed out that a school is justified in regulating student and teachers within the scope of the educational mission and school curriculum. The courts also give credibility to school authorities when making decisions based on legitimate pedagogical concerns. In other words, the courts are more likely to side with a school that makes decisions based on the basic educational mission of the school. This is of concern when examining social networking sites and the issues involving both teachers and students that arise from them. While schools may not be interested in most matter that students post on the internet, this language leaves the door open for a legitimate concern and connection to schools to exist.

The relatively recent case of Deborah Morse v. Joseph Frederick clarified for schools not only what language they may sanction but also when they may sanction such language. ${ }^{124}$ Joseph Frederick was attending an event off school grounds but during the school day and sanctioned by the school. Principal Morse noticed Frederick when he unfurled a sign that read "Bong Hits 4 Jesus." Principal Morse believed that the statement was promoting drug use and directed the students to take the banner down. Frederick refused to take the sign down and Principal Morse confiscated the sign. Morse

${ }^{123}$ Hazelwood School District v. Kuhlmeier, 484 U.S. 262 (1988).

${ }^{124}$ Morse v. Frederick, 551 U.S. 393 (2007). 
later suspended Frederick for the sign that advocated drug use, which violated school policy. Frederick sued claiming his first amendment rights were violated. ${ }^{125}$

The Supreme Court responded that there was not a first amendment violation.

First and foremost the courts rejected the notion that this was not a school speech case, which Frederick attempted to argue, as the event was during school hours and sanctioned by the school. As a school sponsored event, teachers and administrators were among the students, responsible for them, and school rules were in effect.

The court also found that since at least two different interpretations of the sign existed, one promoting drug use and one pointing out celebrity drug use, it was reasonable for school officials to believe the sign was promoting drug use. Therefore, the school was within its bounds in demanding the sign come down and disciplining the student for displaying the sign. ${ }^{126}$

The Supreme Court cited a number of other landmark cases in explaining why schools have a responsibility for protecting the children they serve from lewd or inappropriate language including but not limited to drug abuse. The cases and amendments mentioned include Bethel v. Fraser; Tinker v. Des Moines; Vernonia v. Acton; the first amendment; the fourth amendment; and the Safe and Drug-Free Schools and Communities Act. ${ }^{127}$

The significance of the Morse v. Frederick case in the context of technology is that it allows school administrators to address issues that do not necessarily occur within their walls. Technological issues often occur or at least begin elsewhere and then become

\footnotetext{
${ }^{125}$ Morse v. Frederick, 551 U.S. 393 (2007).

${ }^{126}$ Morse v. Frederick, 551 U.S. 408 (2007).

${ }^{127}$ Safe and Drug Free Schools Act. 20 U. S. C. \$7114(d)(6) (2000 ed., Supp. IV).
} 
a problem at school. This case gives schools latitude to deal with issues that will affect students in an unhealthy manner at school sponsored events. In this case, the good of not promoting drug use out-weighed any free speech issue that may arise, “...because schools take steps to safeguard those entrusted to their care from speech that can reasonably be regarded as encouraging illegal drug use."128

While all of these cases have helped define the extent and scope of school authority, they do not completely address the issues that arise in the modern technological age. In each instance the infraction occurred at school, at a school sponsored event, or with a clear tie to the school. The internet and smart phones have blurred the lines of what exactly it means for speech to have occurred on school grounds. Messages and opinions posted at home can reach students in an instant at home and at school, as one author points out, “...once courts are able to understand the boundary-less location of the internet, the applicability of Tinker becomes more comprehensible." ${ }^{129}$

\section{Fourth Amendment Cases}

The Constitutional Amendment that protects the general citizenry from random searches by the government is the fourth amendment. The fourth amendment provides, “...the right of the people to be secure in their persons, houses, papers, and effects against unreasonable searches and seizures," and guarantees that right, "shall not be violated, and no warrants shall issue, but upon probable cause, supported by oath or affirmation, and particularly describing the place to be searched, and the person or things to be seized."130

\footnotetext{
${ }^{128}$ Morse v. Frederick, 127 U.S. 2618, (2007).

${ }^{129}$ Samantha M. Levin. "School Districts As Weatherman: The School's Ability to Reasonably Forecast Substantial Disruption To The School Environment From Students' Online Speech." Fordham Urban Law Journal. Vol. 38, no. 3 (March 2011): 868. Academic Search Complete, EBSCOhost (accessed July 1, 2012).

${ }^{130}$ U.S. Constitution, amend. 4.
} 
To the ordinary United States citizen this means the government or its agents cannot conduct a search unless there is probable cause of finding wrong doing. The standard is different for school children. Through the years, the courts have decided that schools must have the ability to deal with unexpected and varying circumstances without the standard of probable cause.

The case of New Jersey v. T.L.O. set the standard for school officials searching students. ${ }^{131}$ A teacher discovered a 14 year old female student and a companion smoking in a lavatory in violation of a school rule. She escorted both to the Principal's office where the Assistant Vice-Principal met them. The Assistant Vice-Principal questioned the respondent who denied smoking. The Assistant Vice-Principal subsequently searched the purse and found a pack of cigarettes, pack of rolling papers, some marijuana, a pipe, plastic bags, a fairly substantial amount of money, an index card with a list of names that owed money, and two letters with content that discussed drug dealing. ${ }^{132}$

There were a couple of key standards to come out of this case in regards to student search and seizures. The judgment in this case will serve as the baseline for student searches from 1985 forward. The first key standard to come out of this finding is that schools do not function merely as surrogates of the parent at all times but rather do function as representatives of the state in carrying out searches and other functions in relationship to disciplinary policies. Additionally, the court recognized that school children do not shed all of their fourth amendment protections at the school gate. ${ }^{133}$

\footnotetext{
${ }^{131}$ New Jersey v. T.L.O., 469 U.S. 325, (1985).

${ }^{132}$ New Jersey v. T.L.O., 469 U.S. 325 (1985).

${ }^{133}$ New Jersey v. T.L.O., 469 U.S. 325 (1985).
} 
The second element of this decision recognized, however, that schools had to tend to the delicate balance between the students' expectations of privacy and the schools' equally legitimate need to protect the learning environment. The Supreme Court declared that it was necessary for a loosening of the restrictions which public authorities are ordinarily subject. The Supreme Court further stated that school officials need not meet the standard of probable cause to conduct a search as police must, but the standard would be reasonableness. By reasonableness the Supreme Court defined the determining factors as, “...whether the search was justified at its inception and whether, as conducted, it was reasonably related in scope to the circumstances that justified the interference in the first place."134

The Supreme Court further defined reasonableness as justified at inception if there are reasonable grounds to suspect the search will turn up evidence of wrongdoing in terms of laws or school rules. Reasonableness in scope was clarified as meaning, “...the measures adopted were reasonable related to the object being searched for and that they not be excessively intrusive in light of the student's age, sex, and nature of infraction." 135

This case is the measuring stick for conducting searches in public schools today. It challenged the concept of in loco parentis, which schools acted under the protection of for centuries. The language chosen by the Supreme Court for this case will serve as a test that school officials must pass when conducting student searches. The "excessive intrusion" measure was even cited as the reason Savanna Redding won her lawsuit in 2009 against a school district for a strip search conducted when she was 13 in search of

\footnotetext{
${ }^{134}$ New Jersey v. T.L.O., 469 U.S. 342 (1985).

${ }^{135}$ New Jersey v. T.L.O., 469 U.S. 343 (1985).
} 
prescription strength ibuprofen. The implications regarding searches of and discipline from technology are directly related.

The case of Vernonia School District 47Jv. Wayne Acton set the stage for placing restrictions on participation in extra-curricular activities based on submitting to a search. ${ }^{136}$ This case upholds Code of Conduct requirements and also opens the door for addressing technological issues for those students who participate in extra-curricular activities.

The Vernonia School District saw a change in student behavior in the mid 1980's. The students in Vernonia began speaking out about their attraction to the drug culture, disrupting classes, blurting out profanity on a regular basis, and receiving discipline referrals at a rate double the number averaged in the early 1980s. The students also boasted that there was nothing the schools could do about it as the drug use was not happening at school. The student athletes in the district were not only a part of the group promoting drug use but appeared to be some of the leaders, according to the teachers and administration.

The Vernonia School District first addressed the issue by hosting special classes, presenting speakers, and bringing in drug detection dogs to curb the problem, yet it persisted. The School District then held an open forum for parent input to discuss a policy to address the issue of drug usage. The parents that attended the meeting gave their unanimous support to the school for enacting a drug testing policy for studentathletes.

${ }^{136}$ Vernonia School District 47J v. Wayne Acton, 515 U.S. 646 (1995). 
The Acton lawsuit was brought against the Vernonia district when a seventh grader in one of the schools, James Acton, was denied participation in football because his parents refused to sign the drug testing consent form. The parents of James Acton brought action on grounds of Fourth Amendment and Fourteenth Amendment violations.

The Supreme Court heard this case and decided that the Vernonia School District had violated neither the Fourth nor the Fourteenth Amendment rights of Acton. The reasoning the Supreme Court gave rested on the reasonableness of a search, which they argued is judged in this case by, "...balancing the intrusion on the individual's Fourth Amendment interests against the promotion of legitimate governmental interests." ${ }^{137}$ The school functions as state overseer of children and holds certain rights by requiring vaccinations and physical examinations, which shows that the schools exert more control over children than the government does over free adults. Student athletes, by voluntarily trying out or signing up for a team, are subject to even less privacy expectations.

The Supreme Court also argued that the method of collecting urine for the drug test was minimally obtrusive, as the testing environment was similar to the environment in a public restroom. The tests also looked for commonly abused drugs with results going to a limited group as opposed to being released to the public. Additionally, the good intended by the policy in deterring drug use by school children and preventing bodily harm through participation in sports under the influence of drugs outweigh the individual privacy expectations that the students held. ${ }^{138}$

The Vernonia v. Acton case has bearing on the current technological era. The idea of the good being served by a search or policy outweighing the privacy expectation of the

${ }^{137}$ Vernonia School District 47J v. Wayne Acton, 515 U.S. 646 (1995). 
student is key to this case. Applied to cell phones, a policy of searching phones for a legitimate purpose such as drug dealing or harassment issues would have more merit in court than a random search. The school district in this case also demonstrated that there was a legitimate and documented problem that needed to be addressed. A school administrator would be wise to follow this example. The court here demonstrated that schools need to meet unforeseen challenges and have some latitude that the government would not with free adults.

The case of Vernonia $v$. Acton supported the random drug testing of student athletes. The case of the Board of Education of Independent School District No. 92 of Pottawatomie County v. Earls supported schools in testing all student athletes and activity members as a condition for participation. ${ }^{139}$ Tecumseh Oklahoma School District adopted a student activity drug testing policy where by all student athletes and activity participants must submit to urinalysis testing as part of the terms for participation. The policy was written to include all activities but was only applied to competitive extracurricular activities sanctioned by the Oklahoma Secondary Schools Activities Association (OSSAA). Two students brought suit for violation of their fourth amendment rights.

The Supreme Court ultimately sided with the School District and found no fourth amendment violation had taken place. The Court referenced the Vernonia v. Acton case as a starting point for deciding this case and expanded the ruling to include testing all participants based on three factors. The first factor the Supreme Court addressed was the nature of the students' expectation of privacy. The parties that brought the suit argued

${ }^{139}$ Board of Education of Independent School District No. 92 of Pottawatomie County v. Earls, 536 U.S. 822 (2002). 
that activities were different than those participating in athletics, as they were not subject to annual physicals or dressing in locker rooms together. As these are distinct differences, the families argued the students had a different expectation of privacy. The Supreme Court denied this argument and stated that all activities were subject to regulation by the OSSAA. ${ }^{140}$

The next factor to consider by the courts was the invasion of privacy caused by the collection method. The Court argued that as the method was almost identical to the method from the Vernonia case, there was again no fourth amendment violation.

Finally, and most importantly, the Court stated that the interest served in preventing school aged children from using illegal drugs far outweighed the rights of individual students participating in extracurricular activities. The school demonstrated that there was a concern for student drug use in the community by presenting teacher testimony, detailing how a drug dog found drugs and paraphernalia, and describing phone calls to the Board of Education to address the drug issue by concerned community members. ${ }^{141}$ The Supreme Court ultimately decided that “...the need to prevent and deter the substantial harm of childhood drug use provides the necessary immediacy for a school testing policy...it was entirely reasonable for the School District to enact this particular drug testing policy."142

In the modern technological age, the rationale here is as important as the decision. The reason the wide sweeping drug testing policy was found to be acceptable was

\footnotetext{
140 Board of Education of Independent School District No. 92 of Pottawatomie County v. Earls, 536 U.S. 822 (2002).

141 Board of Education of Independent School District No. 92 of Pottawatomie County v. Earls, 536 U.S. 822 (2002).

142 Board of Education of Independent School District No. 92 of Pottawatomie County v. Earls, 536 U.S. 824 (2002).
} 
because the policy faced a serious and documented problem. In terms of creating a technology limitation or search policy, a school district would need to demonstrate an equal threat. While most of the current cases rest on the standard of disruption to the academic environment, the Supreme Court demonstrated here in the Earls Case that safety is a legitimate concern that it will support as well. If a school district could demonstrate that drug deals were being conducted exclusively by phone or text, or that violence was being organized by like means, or that bullying was being conducted online and carrying over to school, they would have a greater chance of earning the support of the courts in creating a policy to address such issues.

The question yet exists of how far can a school take a search of a student? The answer is dependent upon a number of factors and the case of Safford Unified School District $\# 1$ v. Redding helped to clarify what exactly those factors are. ${ }^{143}$ Savana Redding was a 13 year old student when the incident that led to this case occurred. She was brought to the Assistant Principals' office for questioning regarding prescription strength and over the counter pain pills. A fellow student was found in possession of a planner that contained a knife and the pain pills. The student said that all the items belonged to Savana. Savana acknowledged that the planner was hers but denied any knowledge of the other items. The Assistant Principal informed Savana that he had information that she was distributing the pills to other children. Savana denied the report and allowed the Assistant Principal to search her bag. The male AP and his female administrative assistant searched the bag and found nothing. The Assistant Principal then had the female assistant take Savana to the nurse's office and searched her clothing in the

143 Safford Unified School District \#1 v. April Redding, 129 S.Ct. 2633, (2009). 
presence of the female nurse. The two women had Savanna remove her outer clothing to be searched and then instructed her to pull her bra and waistband away from her body and shake them out. No pills were found at any point during the entire search. Savanna Redding and her mother filed suit claiming Fourth Amendment violations.

The case of Safford v. Redding went a long way toward clarifying the limits that exist for a school district in searching a student. The basic guideline for searching a student as set forth by the Supreme Court in the New Jersey v. T.L.O. case is reasonableness. A school official may conduct a search if there is a moderate chance that they will uncover wrongdoing during the search. The scope of the search must be reasonable in relationship to the contraband being sought. In the Safford v. Redding case, the Supreme Court felt the initial search was reasonable in light of recent previous incidents involving alcohol and tobacco as well as the student information obtained about Savana Redding. The search of the bag and outer clothing were reasonable. The Supreme Court pointed out that the New Jersey v. T.L.O. case already clarified that school searches need to be "...reasonably related to the objectives of the search and not excessively intrusive in light of the age and sex of the student and the nature of the infraction." $" 144$ In other words, strip searching a 13 year old for aspirin is taking a search too far. "Savana's subjective expectation of privacy is inherent in her account of it as embarrassing, frightening, and humiliating. The reasonableness of her expectation is indicated by the common reaction of other young people similarly searched; whose adolescent vulnerability intensifies the exposure's patent intrusiveness." ${ }^{\prime 15}$

\footnotetext{
${ }^{144}$ New Jersey v. T.L.O., 469 U.S. 325 (1985).

${ }^{145}$ Safford Unified School District \#1 v. April Redding, 557 US 363 (2009).
} 
Public school administrators should view the Safford case as a reminder of the goal of searching a student. The entire search should be reasonable in what an administrator expects to find and the means should be reasonable based on the risk or concern of the item sought. The question of whether or not a strip search is permissible was not answered. The clarification came from the courts that if an administrator is going to strip search a child in any manner, there had better be an imminent danger to warrant such a search. 


\section{CHAPTER IV}

\section{RECENT ISSUES FOR SCHOOL AUTHORITY Off-campus Speech That Makes its Way on Campus}

There have been cases regarding off-campus student speech online that makes its way on campus that have moved from the state to the federal level thus far, even if the Supreme Court has not taken up the issue just yet. The cases that follow all concern offcampus internet speech that makes its way on campus and results in some form of discipline. As mentioned previously, the cases are decided on a highly fact-specific basis and call upon one or more of the previously mentioned cases that stem from Tinker. The first set of cases that follow resulted in the courts finding in favor of the students while the second set resulted in the courts finding in favor of the schools. While not all cases that have risen to the federal level are included in these groups, a sampling of each side does reflect the general nature of the cases that have made it to the federal level thus far.

\section{Courts Side With Students}

The case of Jack Flaherty v. Keystone Oaks School District arose from comments posted on the internet from both home and school computers. ${ }^{146}$ The interesting point to note in this case is that the issue of a nexus existing was not relevant, but rather the policy used to discipline the student was examined.

Jack Flaherty Jr. was a high school student in Keystone Oaks School District. Jack made internet posts on a message board that negatively critiqued the Keystone boys'

\footnotetext{
${ }^{146}$ Flaherty v. Keystone Oaks School District, 247 F. Supp. 698 (2003).
} 
volleyball team. One of Flaherty's messages said that an opposing player's mother, who teaches at Keystone Oaks, was a bad art teacher. The posts further questioned the team's ability to win in an upcoming match with Baldwin High School. The Principal disciplined Jack in accordance with the policies set forth in the School Handbook. Flaherty was kicked off the volleyball team, prohibited him from attending any afterschool events and refused access to school computers for any purpose. His parents sued claiming that the school policies contained in the handbook were overbroad and that the principal was simply punishing Jack for brining negative attention to the volleyball team. The lawsuit stated that such conduct did not rise to the level of substantial disruption called for in Tinker v. Des Moines.

The courts sided with Flaherty in this case. The first point the courts made was that the policies were overbroad and unconstitutionally vague because, as demonstrated here, they were interpreted to violate, “...speech that is protected under the First Amendment." ${ }^{\text {147 }}$ The specific missing element from the policies that the courts mentioned was geographic limitation. The schools are limited to the school grounds, school sponsored events, or events with a nexus to the school. The courts provided more specific detail in explaining that the policies should be linked somewhere in the text, “...to speech that substantially disrupts school operations." ${ }^{\text {148 }}$ The court also offered that policies should provide students with adequate warnings as to what conduct is prohibited.

Administrators would do well to consider Flaherty v. Keystone on two levels. The first level would be to re-examine existing policy in terms of over-broadness and vagueness according to the guidelines mentioned. The second level of consideration

\footnotetext{
${ }^{147}$ Flaherty v. Keystone Oaks School District, 247 F. Supp. 705 (2003).

${ }^{148}$ Flaherty v. Keystone Oaks School District, 247 F. Supp. 706 (2003).
} 
would be in the application of the policies and, as in most cases, the substantial disruption test provided through Tinker v. Des Moines.

The case of Joshua Mahaffey v. Peni Aldrich was brought after Joshua Mahaffey was suspended from school for a website he created that professed that he hated school and joked of wanting fellow classmates to die. ${ }^{149}$ Mahaffey was suspended from school pending a hearing and through a number of random events ended up missing almost the entire semester before receiving a letter that stated he could return to school for second semester. The student sued for violations of his first and fourteenth amendment rights and the court decided in his favor.

Joshua Mahaffey was a student at Waterford Kettering High School when he created a webpage with a friend for laughs and because he was bored, according to his own testimony. The webpage was titled "Satan's Webpage" and in an introduction stated, "This site has no purpose. It is here to say what is cool, and what sucks. For example, music is cool. School sucks." ${ }^{\prime 50}$ The webpage also listed sections titled, “...people I wish would die, people who are cool, and movies that rock." ${ }^{151}$ A section was also present that contained a mission for the week that depicted a violent act of murder as well as a disclaimer that stated, "Now that you've read my webpage, please don't go killing people and stuff then blaming it on me, ok?"152

The webpage was brought to the attention of the police department by a parent of a student at Waterford Kettering. The police officer who interviewed Mahaffey notified Waterford Kettering Principal Carol Baldwin that Mahaffey said one of the school

\footnotetext{
${ }^{149}$ Mahaffey v. Aldrich, 236 F. Supp. 2 d 779 (2002).

${ }^{150}$ Mahaffey v. Aldrich, 236 F. Supp. 2d 781 (2002).

${ }^{151}$ Mahaffey v. Aldrich, 236 F. Supp. 2d 781 (2002).

${ }^{152}$ Mahaffey v. Aldrich, 236 F. Supp. 2d 781 ( 2002).
} 
computers may have been used in creating the webpage. Principal Baldwin suspended Mahaffey on August 28, 2001 after a meeting regarding the webpage was held at the Waterford Police Department. In a letter dated September 7, 2001 Principal Baldwin informed Mahaffey's parents that she was recommending an expulsion to Peni Aldrich, Director of High School \& Continuing Education.

A letter dated September 12, 2001 from Aldrich informed the Mahaffey parents of a hearing on the $20^{\text {th }}$ of September. Aldrich cancelled that hearing as Joshua Mahaffey was withdrawn on September 13, 2001. The attorney for the Mahaffey Family sent a response letter dated September 19, 2001 stating that Joshua was not withdrawn but rather enrolled in another district because the Waterford district was not providing an education. The situation became further convoluted on October 9, 2001 when the Mahaffey attorney sent another letter to Aldrich stating they wished to re-enroll their son on the $15^{\text {th }}$ of October. Aldrich set a hearing for the $17^{\text {th }}$ of October to deal with the expulsion issue at that time. On October 17, 2001, the meeting was finally held. The hearing began pursuant to the prescribed protocol for a discipline hearing but concluded after several exchanges between Aldrich and the Mahaffey attorney and with Aldrich saying, "I'm sorry, this is not working.",153

A letter was sent on the $27^{\text {th }}$ of November by Aldrich informing the Mahaffey family that she was not recommending expulsion and that Joshua Mahaffey could reenroll the following semester. The Mahaffey parents sued on behalf of their son, claiming that his first and fourteenth amendment rights had been violated. The District court agreed with the Mahaffeys in this case. In examining the specifics of this particular

${ }^{153}$ Mahaffey v. Aldrich, 236 F. Supp. 2d 784 (2002). 
case, the court found that there was no disturbance at school what so ever, and that the substantial disruption described in the Tinker case was not evident. Furthermore, the court was reluctant to apply the Tinker standard as the speech in question appeared to be entirely off campus. The court granted judgment in favor of the student on both the First Amendment claims and the Fourteenth Amendment claims. The true threat standard was also addressed with the court pointing out that no reasonable person could interpret the webpage as being a true threat against fellow students. ${ }^{154}$

This case is an example of how a school district did not give due diligence to a investigating an incident as well as not affording due process. The school district never conducted an investigation of its own outside of the police information. There was no investigation as to whether or not a school computer was used in making the webpage. The school also did not follow the standard protocol in a discipline hearing as Mahaffey's counsel was not allowed to cross examine witnesses or address the issues. The hearing was going so poorly the hearing officer simply concluded it, saying "this is not working." While this case has a webpage issue at the inception, it appears to be a reminder to school administrators to pay attention to detail and be sure to handle school business with school personnel in a school manner.

The case of T.V. and M.K. v. Smith-Green Community School Corporation was brought when students were suspended from extra-curricular activity for provocative photos of a sexual nature taken off school grounds and posted to the internet. ${ }^{155}$

\footnotetext{
${ }^{154}$ Mahaffey v. Aldrich, 236 F. Supp. 2d 786 (2002).

${ }^{155}$ T.V. ex rel. B.V. v. Smith-Green Community School Corporation, No. 1:09-CV-290PPS, (2011).
} 
T.V. and M.K. were entering the 10 the grade in the summer of 2009. Both girls were involved in volleyball and M.K. was also involved in cheerleading and show choir. The girls and some of their friends had three separate sleepover parties prior to tryouts for volleyball in July. At the three parties T.V. and M.K. had phallic shaped rainbow covered lollipops. The girls took various photographs with the lollipops ranging from simulating oral sex, to holding them between their legs, to simulating anal sex. The girls are wearing clothes or pajamas in most pictures, with M.K. wearing lingerie in one, with money stuck in the side "stripper-style". The girls then uploaded these pictures to Facebook, MySpace, and Photo Bucket accounts. In each case, "friends" or people given a password were able to view the photos which had captions added such as, “...wanna suck on my cock." ${ }^{156}$

The photographs were brought to the attention of the Superintendent by a parent who claimed they were causing division among the volleyball team between those girls who condoned such behavior and those who did not. The Superintendent turned the matter over to the principal and instructed him to handle it according to the code of conduct. The Principal investigated the matter, confirmed with the girls that the pictures were of the two of them, and explained that they violated a portion of the code of conduct. The specific section that the principal cited to the girls was, "If you act in a manner in school or out of school that brings discredit or dishonor upon yourself or your school, you may be removed from extra-curricular activities for all or part of the year."157 The principal informed the students and their parents that the girls would be suspended

\footnotetext{
${ }^{156}$ T.V. ex rel. B.V. v. Smith-Green Community School Corporation, No. 1:09-CV-290PPS, 2 (2011).

${ }^{157}$ T.V. ex rel. B.V. v. Smith-Green Community School Corporation, No. 1:09-CV-290PPS, 6 (2011).
} 
from extra-curricular activities for a year, with the possibility of a reduction to twenty percent of a season if they visited a counselor and apologized to the athletic board for their behavior, which both girls did.

This case is clearly off-campus speech being regulated by schools with discipline being handed down as a result. The case is different in that the discipline applied only to extra-curricular activities and amounted to a six game volleyball suspension. The court mentions in the decision that, "This cannot be what the Supreme Court had in mind when it enunciated the 'substantial disruption' standard in Tinker v. Des Moines." Nonetheless, the Court found that the photographs did not meet the standard presented in Tinker. There was little to no disruption caused by the photographs or their posting. The Court therefore sided with the students. Furthermore, the Court found that the language of the code of conduct that authorized discipline for out of school conduct that brings dishonor or discredit upon the school was so vague and overbroad as to violate the Constitution. This decision sets interesting parameters for student code of conduct agreements as they are often times based on off-campus activity and specifically vague in nature by design.

Another interesting note to this case as pointed out by the court is the issue of right to participate in extra-curricular activity. The court points out, “...that there is not a constitutional right to participate in athletics or other extracurricular activities may be pertinent to an analysis of other sorts of constitutional claims...but as Tinker itself notes, not to a freedom of expression claim."

\footnotetext{
${ }^{158}$ T.V. ex rel. B.V. v. Smith-Green Community School Corporation, No. 1:09-CV-290PPS, 24 (2011).

${ }^{159}$ T.V. ex rel. B.V. v. Smith-Green Community School Corporation, No. 1:09-CV-290-
} 
The case of Beussink v. Woodland R-IV School District is one of the most straightforward cases here presented. The student created a webpage, at home on his own computer, that used vulgar language and was highly critical of the school he attended and the administration. The principal, Mr. Poorman, issued a 10 day suspension based on the content of the webpage. The student brought suit for violation of his First and Fourteenth amendment rights. ${ }^{160}$

The webpage created by Beussink came to the attention of the school when another student, who was a former friend of Beussink, showed the webpage to a teacher. No other student was present when this occurred. The teacher did allow another student to access the webpage later in the day. The student was already aware of the webpage and the teacher was leading an educational discussion relevant to the idea of the webpage. No other students in the school appeared to have accessed the webpage using a school computer. Upon being notified by the classroom teacher of the website, principal Poorman decided immediately to punish Beussink. He sent notice to Beussink in class that he would be suspended 5 days. Principal Poorman rethought the discipline and later in the day issued a second notice of discipline to the student stating the penalty was to be increased to 10 days of suspension. Beussink went to talk to him at the end of the day, but the principal would not reconsider the discipline. During that meeting, Poorman told Beussink to, “...clean up your webpage or clear it out."161 Beussink served his 10 day suspension, which brought his semester total of days missed to 18.5. This is relevant because under the Woodlawn attendance policy, he would lose a letter grade for each PPS, 30 (2011).

${ }^{160}$ Beussink v. Woodland R-IV School District, 30 F. Supp. 1175 (1998).

${ }^{161}$ Beussink v. Woodland R-IV School District, 30 F. Supp. 1180 (1998). 
unexcused absence over 10 that he accumulated. This suspension ultimately dropped all his grades 8.5 letter grades. At the time of his suspension, he was passing 4 classes and failing 2 classes.

The court granted summary judgment to the student. The court expressed that, “...disliking or being upset by the content of student speech is not an acceptable justification for limiting student speech under Tinker."162 This case is a clear cut student expression case in the courts' eyes, even if it occurred off campus. The school did not even attempt to show that a disruption had occurred, but rather the principal admitted he was angered by the content of the webpage. The school did not raise the Fraser standard in this case, which would have dealt more directly with content. In all likelihood, that standard would not have been met either. The principal condemned his own actions by admitting he did not like the content of the webpage. This is precisely the type of authoritative abuse Tinker protects against.

The case Laura Neal v. Jerry Efurd was brought by a parent when Justin Neal and Ryan Kuhl were suspended for creating off-campus websites that were critical of their school. The case is another example of the Tinker standard coming into play as well as the true threat standard being analyzed. ${ }^{163}$

Justin Neal and Ryan Kuhl were students at Greenwood High School in 2004. In August, before the start of the school year, each created a website of his own, on their home computers, each critical of Greenwood School. Neither boy utilized school equipment to construct, maintain, or access their respective websites. Shortly before the first day of school, a parent contacted the principal of Greenwood High School, Jerry

\footnotetext{
${ }^{162}$ Beussink v. Woodland R-IV School District, 30 F. Supp. 1182 (1998).

${ }^{163}$ Laura Neal v. Jerry Efurd, Civil No. 04-2195, (2005).
} 
Efurd, about the websites. The parent complained about the way athletes and band members were portrayed on the sites, and about hateful language on the websites. The vice principal, Jim Garvey, at the request of Efurd began an investigation on the $24^{\text {th }}$ of August. Neal, Kuhl, and two other boys who made posts on the websites were taken out of class and questioned. The boys were not allowed to return to class that day. On the $25^{\text {th }}$ of August all four boys were suspended for a period of three days.

At the close of the day on August $24^{\text {th }}$, Efurd sent an e-mail to the high school faculty stating that the four boys, “...had been suspended because of threatening statements they made (on several websites) regarding a couple of staff members." 164 Efurd would testify that the e-mail was meant to have a calming effect. He also would later admit that no such threatening statements were contained on either website. The written notice provided to Neal as to the reason for his suspension includes the following two points:

1. "Providing a website and linking the site to an inappropriate website that encouraged mayhem and dissension among GHS students

2. Providing images of school administration conducting violence toward students." 165

At trial, Efurd would testify that he did not think either Neal or Kuhl were dangerous to staff, but that he perceived a danger of disruption in the content of their websites and that he was concerned that the sites would cause disruption at the school between groups offended by the content. Efurd also testified that the websites tended to harass, intimidate, and instill fear in other students, which is the definition of harassment. He did not note bullying or harassment as a reason for suspension, however.

\footnotetext{
${ }^{164}$ Laura Neal v. Jerry Efurd, Civil No. 04-2195, 5 (2005).

${ }^{165}$ Laura Neal v. Jerry Efurd, Civil No. 04-2195, 6 (2005).
} 
Through the course of the legal proceedings, a number of teachers testified. Most of the teachers stated that they did not want to be ridiculed on a website, and feared that they might be targeted on the website. None of the teachers actually viewed the website nor did they experience any disruption to the educational environment associated with the website. Most of the concerns expressed by the teachers seemed to stem from gossip about the websites. The websites contained only one statement, posted by a visitor to one site that was even close to threatening. That statement suggested that students damage the football field. The majority of each website was dedicated to message boards where visitors could leave posts about issues ranging from financing for athletics to the need to increase teachers' pay. Each website contained a website depicting the administration as cartoon characters in an unflattering light.

The court predictably sided with the students in this instance. In examining this case, the court applied the Tinker standard and found that, “...the expression of complaints by a small percentage of students and the largely unfounded apprehensions of a few teachers do not constitute substantial disruption of the educational environment." 166 The court also went on to suggest that the administration could not predict a disruption based on the content of the websites alone.

The court also addressed the true threat issue and found that no true threat existed as no reasonable person could have interpreted either website to contain a true threat towards anyone. The court found that the school district violated the First Amendment Rights' of the students because there was no substantial disruption and no true threat.

\footnotetext{
${ }^{166}$ Laura Neal v. Jerry Efurd, Civil No. 04-2195, 23 (2005).
} 
This case provides an example of how the mere unpleasantness of an opinion is not enough to suppress free speech.

The 2000 case of Nick Emmett v. Kent School District No. 415 was a result of a 5 day suspension issued to a student for creating an unofficial webpage for his high school which included mock obituaries of fellow students and a place for visitors to vote on who should "die" next. ${ }^{167}$

Nick Emmett was an 18 year old senior at Kentlake High School in 2000. He carried a grade point average of 3.95 , had no disciplinary record, and was co-captain of the basketball team. In February of 2000 he created an "Unofficial Kentlake High Home Page" from his home computer without using school resources or time. The page had a prominently displayed disclaimer stating the website was not sponsored by the school and for entertainment purposes only. The webpage contained commentary on the school administration and faculty as well as mock obituaries inspired by a creative writing assignment in which students were to write their own obituaries. There was also a section of the webpage where visitors could vote for who would die next, or who would be the subject of the next mock obituary.

On February 16, an evening television story ran characterizing the webpage as a "hit list" of people to kill. Those words appear nowhere on the webpage. Nick Emmett took down the page that night. The following day Emmett was summoned to the principal's office and notified that he was placed on emergency expulsion for intimidation, harassment, disruption to the educational process, and violation of Kent School District Copyright. The emergency expulsion was modified shortly thereafter to a

${ }^{167}$ Nick Emmett v. Kent School District No. 415, 92 F. Supp. 1088 (2000). 
5 day suspension. There was no evidence presented by the administration that any student felt threatened nor were any threats or evidence of harassment presented.

The court found in this case that the speech was entirely off-campus and therefore the school violated the student's first amendment rights. The court did not apply the Tinker standard nor the Fraser standard, as the speech was deemed to be out of the jurisdiction of the school to issue discipline. This case is interesting in that the court did not even bother with pursuing the issue beyond the concept of off-campus speech. In most of the cases examined thus far, the schools have failed to meet the Tinker standard. In this case, the court felt the schools simply over stepped their bounds in addressing the issue in the first place.

Student JC brought case against Beverly Hills School District for violation of her first and fourteenth amendment rights in J.C. v. Beverly Hills Unified School District. The case addresses free speech issues arising outside of school, posted on the internet, and connected to the school through the subject of the speech in question. ${ }^{168}$

JC was a student at Beverly Hills School District when the incident in question occurred. She and a group of friends gathered at a restaurant after school one afternoon and videotaped themselves talking about a classmate referred to by name in the video. The conversation was disparaging in nature and referred to the classmate in question as "spoiled", a "slut", "the ugliest piece of shit I've ever seen", and someone who talks about "boners". JC is heard throughout the video encouraging her friends to continue the comments. ${ }^{169}$

\footnotetext{
168 J.C. v. Beverly Hills Unified School District, 711 F. Supp. 1094 (2010).

169 J.C. v. Beverly Hills Unified School District, 711 F. Supp. 1097 (2010).
} 
The same evening, JC posted the video to YouTube and contacted approximately 6 friends and encouraged them to view it. JC also called the subject of the video and told her it was on YouTube. The subject of the video told JC the video was mean, at which point JC asked if the subject would like the video taken down. The subject's mother instructed the subject to have JC keep the video up, as she intended to call the school the next day. JC estimated that 15 people saw the video that night, while the video itself recorded 90 hits that night.

The following day, the subject of the video came to school with her mother and spoke immediately to her counselor. She told her counselor that she felt humiliated and her feelings were very much hurt. The subject of the video also indicated she did not want to go to class that day. The counselor spent around one half hour with the subject and finally convinced her to go to class.

The school counselor informed the administrators in the building of what had occurred. The administrators began calling down JC and the other students in the video and had each write a statement about the video and the creation of the video. JC was suspended two days for her role in making the video and posting it on YouTube. No other students received discipline for being video-taped or making comments in the video. The school noted that JC had been previously disciplined for videotaping at school.

The second district court sided with the student in this case. The courts again applied the Tinker standard to determine if the off campus speech is protected by the first amendment. In this case, the courts pointed out that, “...the school did not present 
evidence that [the administrators] missed or were late to any other school activities." The court further mentioned that it was not clear that dealing with the issue was beyond the scope of an administrator's normal daily activity. This essentially means there was no evidence of any disruption to school, let alone a substantial disruption.

The confusing element from this case comes from the explanation from the court. The court stated they, “...cannot uphold school discipline of student speech, simply because young persons are unpredictable or immature, or because, in general, teenagers are emotionally fragile and may often fight over hurtful comments." ${ }^{171}$ This leaves some uncertainty as to predicting a disruption. Some courts have stated that demonstrating a potential disruption is enough to uphold discipline for speech. This case provides a counter argument, as most school administrators can point out numerous examples of such language causing substantial disruptions to the school environment. This demonstrates the necessity of the Supreme Court stepping in and giving a definitive answer as to the extent of school authority to discipline, or at least clarifying the guidelines school administrators should follow in gauging disruption to the school day or regulation of student language.

The case of Katherine Evans v. Peter Bayer was filed when Katherine Evans received discipline for making a Facebook group about her teacher, Ms. Sarah Phelps. The case is a specific example of school discipline being applied for comments posted on the internet. $^{172}$

\footnotetext{
${ }^{170}$ J.C. v. Beverly Hills Unified School District, 711 F. Supp. 1134 (2010).

171 J.C. v. Beverly Hills Unified School District, 711 F. Supp. 1136 (2010).

${ }^{172}$ Katherine Evans v. Peter Bayer, 684 F. Supp. 1365(2010).
} 
Katherine Evans was a senior at Pembroke Pines Charter School. On her home computer after school hours, Katherine created a group on Facebook with the title, "Ms. Sarah Phelps is the worst teacher I have ever met." ${ }^{\prime 17}$ The page contained a photograph of Ms. Phelps but no threats of violence. There were a total of three postings made to the page, all supporting Ms. Phelps and admonishing Katherine. Katherine removed the page after two days. Ms. Phelps never saw the page before it was removed. The school administration was not aware of the posting prior to the page being taken down. The posting came to the attention of the principal after the page was taken down, and he suspended Katherine for three days and changed her class from an AP class to an Honors class. Katherine Bayer filed suit on grounds of first and fourteenth amendment violations.

The courts sided with Katherine Evans in this case. The court again applied the Tinker standard to this case and found the school could not meet the substantial disruption test. The first issue the court addressed was that the speech was “....made off campus, never accessed on-campus, and no longer accessible when the Defendant learned of it." " Additionally, the court went on to state that "....under any form of the Tinker test, Evan's actions cannot be construed as disruptive."175

The Evans v. Bayer case is on point with school discipline involving technology. The case demonstrates that there must clearly be a substantial disruption to the school environment to warrant school discipline. The case also demonstrates that once students leave school, their first amendment rights are the same as all other citizens and they are

\footnotetext{
${ }^{173}$ Katherine Evans v. Peter Bayer, 684 F. Supp. 1365 (2010).

${ }^{174}$ Katherine Evans v. Peter Bayer, 684 F. Supp. 1380 (2010).

${ }^{175}$ Katherine Evans v. Peter Bayer, 684 F. Supp. 1381 (2010).
} 
free to voice their opinions the same as other citizens. The fact that the opinion was about a teacher is not grounds enough for a student to be punished. The opinion may have been different if the posting created a substantial disruption as the Tinker Test has called for. The case may also have been different if the posting was lewd, vulgar, threatening, or promoting illegal or dangerous behavior as in the Bethel v. Frasier case. In the case of Evans v. Bayer, neither the Tinker Test nor the Fraser Test was satisfied.

The case of Joanne Killion v. Franklin Regional School District resulted when the mother of Zachariah Paul filed suit because her son was disciplined for off campus speech that was brought to school by another student. ${ }^{176}$ Paul was a student at Franklin Regional High School and a member of the track team. He was angry because he was denied a parking permit and because certain restrictions had been put in place by the Athletic Director, Mr. Bozzuto. Paul composed and assembled, while at home after school hours, a derogatory top ten list about Bozzuto including topics such as Bozzuto's weight and genital size. This top ten list was then e-mailed by Paul to a number of friends. Paul did not print a hard copy to bring to school because he had been warned in the past that he would be punished if he did so. Several weeks later copies of the top ten list were found in the teachers' lounge at both the high school and middle school. The list had been reconfigured by an undisclosed student and distributed on school grounds.

Paul was called to a meeting in the Principal's office shortly thereafter in which the Assistant Principal and Mr. Bozzuto were also present. In that meeting, Paul admitted authoring the top ten list but denied bringing it to school. He was allowed to return to class. The following day he was again summoned to the office. Anticipating discipline

${ }^{176}$ Killion v. Franklin Regional School District, 136 F.Supp.2d 446 (2001). 
being assigned, Paul called his mother, Joanne Killion, and they together met with the three administrators. The Principal explained to Mrs. Killion that her son was being suspended for ten days for making the offensive remarks about a school official. The principal also notified Mrs. Killion that Paul would not be allowed to participate in track during that time. Mrs. Killion filed the lawsuit for violations of Paul's first and fourteenth amendment rights.

The Second District Court found in favor of the student, Zachariah Paul, in this instance. The court utilized the substantial disruption test from the Tinker case and concluded that the school did not prove an expectation of disruption. The court pointed out that there was no threat made and no actual disruption had occurred. The court also clarified that, “...if a school can point to a well-founded expectation of disruption-especially one based on past incidents arising out of similar incidents-- the restriction may pass constitutional muster."

The court also stated that the school policy regarding student speech was overbroad and vague, as it led to a student being punished for speech that was in fact protected speech. To make the policy constitutional, the school should add a limit as to the geographical reach of the policy or refer to a substantial disruption.

The court in this case referred back to the substantial disruption test of Tinker v. Des Moines to determine if a school can punish a student for Internet speech that occurs off school grounds. While this case does not define all the parameters to consider in disciplining off campus student speech, it does clarify that without a threat or actual

${ }^{177}$ Killion v. Franklin Regional School District, 136 F.Supp.2d 450 (2001). 
disruption, the expectation of disruption needs to have foundation. It is clear that not all potential disruptions will be upheld by the courts as being substantial.

The case of Justin Layshock v. Hermitage School District explored the first amendment rights of students in regards to information posted on the internet. ${ }^{178}$ Justin Layshock was a 17 year old senior at Hickory High School in the Hermitage School District. In early December 2005, Justin created a MySpace profile page that he characterized as a parody of the High School Principal, Mr. Eric Trosh. The profile was created at home, using Justin's grandmother's computer, during non-school hours. There were no school resources used in the profile except a photograph from the school website of Mr. Trosch that Justin obtained through a simple copy and paste action. The majority of the information in the profile centered on the theme of "big." Information and answers on the profile contained comments such as big keg, big fag, big blunt, etc. Justin sent the profile to several friends and soon it reached most of the student body. During this time period at least three other students also created profiles of a similar nature. These other profiles contained more vulgar and offensive statements.

The administration became aware of the profiles by mid-December when a computer teacher saw students looking at one of them and five other teachers reported to the principal that students in class wanted to discuss the pages. Justin on at least one occasion accessed the profile he created from a school computer during Spanish class. There was also evidence that other students viewed Justin's page as the computer teacher saw several students giggling and looking at the page. An investigation ensued which took up the majority of a school day as the assistant principal interviewed a number of

${ }^{178}$ Layshock v. Hermitage School District, 593 F Supp.2d 249 (2010). 
teachers and students. On the $21^{\text {st }}$ of December Justin and his parents met with the Superintendent and no discipline was issued. A letter was sent January 3 stating that a hearing would be held on January 6 . The hearing on the 6 of January resulted in Justin receiving a ten day suspension, being placed in the Alternative Education Program, being banned from all District events, and prohibiting him from participating in the graduation ceremony. Mr. and Mrs. Layshock filed suit against the district for violating Justin's First Amendment right of free speech, among other violations.

The United States District Court decided in favor of Justin Layshock. In the explanation of why the Court made the decision, the court explained that the school district did not meet its burden of proof. The standard for this case was again the Tinker v. Des Moines case. Tinker sets the standard for when a School may regulate speech as being when a material and substantial disruption to the learning environment occurs or could reasonably be expected to occur. The Courts did not feel that the school environment was disrupted by Justin's profile of Mr. Trosch. The Court raised a number of questions as to whether the student-created webpage caused the disruption or if the administrative response to the webpage caused the response. The Court was willing to accept that the profile was lewd or vulgar, but could not determine that a substantial disruption had indeed occurred. "The actual disruption was rather minimal- no classes were canceled, no widespread disorder occurred, there was no violence or student disciplinary action." ${ }^{\prime 19}$ The court found in favor of the school on the other issues brought by the parents.

${ }^{179}$ Layshock v. Hermitage School District, 593 F Supp2d 296, (2010). 
The case of JS v. Blue Mountain School District addresses the suspension of JS for a MySpace.com profile featuring profanity-laced statements and a photograph of her principal, Mr. McGonigle. The case specifically addresses the issue of off campus speech posted on the internet. ${ }^{180}$

JS was a minor student at Blue Mountain Middle School. She created the MySpace page about her principal, Mr. McGonigle, that included a photograph of him but not his name. The page was created by JS in response to what she felt was inappropriate handling of her recent dress code violation by Mr. McGonigle. The comments on the page were profanity-laced and indicated he was a sex addict and pedophile. The profile was created at the student's home and on the student's computer. The page was initially a public page but within a day was set to private, with JS allowing approximately twenty students' access, although not at school. Principal McGonigle suspended JS for ten days for creating the profile after receiving a printout of the page from another student. This printout was the only copy known to have been brought to school. As far as disruption to the school day, it appears three incidents were confirmed. One teacher addressed the issue with a group of students who brought it up in class. One counselor had to cancel appointments with students to deal with the issue. A third teacher had to request a substitute to proctor a test so she could sit in on one of the discussions.

The District Court found in favor of the student in this case. They stated that there was no reasonable forecast for substantial disruption. Furthermore, the courts pointed out, “...if Tinker's black armbands - an ostentatious reminder of the highly emotional and controversial subject of the Vietnam war - could not reasonably have led school

\footnotetext{
${ }^{180}$ J.S. v. Blue Mountain School District, 593 F3d 286, (2010).
} 
authorities to forecast substantial disruption of or material interference with school activities" than neither can the webpage created by JS. ${ }^{181}$

The $J S v$ Blue Mountain case is yet another technology case that looks to the Tinker Test to determine if a school can discipline for out of school internet postings. In this case, the school did not adequately demonstrate that a substantial disruption could be forecast.

The case of Anthony Latour v. Riverside Beaver School District dealt with the issue of off-campus speech and language that may be deemed to be threatening. The courts were asked to lift an expulsion of a student based on these issues. ${ }^{182}$

Anthony Latour wrote four rap songs at home and posted them on the internet. Three of the songs were "battle-rap" songs and violent in nature while one of the songs was about a fellow student. A female student left the district because she felt humiliated by being mentioned in the rap. The school suspended Latour and later expelled him for two years based on the graphic nature and threatening language of the rap songs.

The courts found in favor of the student in this case. The court applied the Tinker standard and found that even though a female student transferred, there was no disruption to the school. The female student testified that she left because she felt humiliated, not because she felt threatened. The young lady had a number of other issues prior to this incident that led to that feeling and this rap song was simply the last straw. The songs were never brought to school nor played at school. The only disruption came from the handling of the issue by the school district.

\footnotetext{
181 J.S. v. Blue Mountain School District, 593 F3d 298, (2010).

${ }^{182}$ Latour v. Riverside Beaver School District, No. 05-1076, 2005 WL 2106562, (2005).
} 
The court also addressed the true threat aspect of the language. The court found that the lyrics were not a true threat as they were, “...just rhymes and are metaphors. Thus, while some rap songs contain violent language, it is violent imagery and no actual violence is intended." ${ }^{183}$ The judge further found that the true threat argument was weakened by the actions of the school. There was no investigation done by the school regardless of a police investigation. The school expelled the student based on a fear that he may hurt other students, yet no search of the student or his locker occurred for a period of over six weeks from the time the police became involved in March until the expulsion hearing in May.

In this case, the court again looked at the school district to meet the substantial disruption test in upholding a student expulsion. The court found there simply was not a disruption to the school day significant enough to warrant the discipline. In fact, the school district demonstrated virtually no disruption to the school day. Furthermore, as the rap songs by Anthony Latour were not written at, nor brought to, school. The student's first amendment rights of expression were intact outside the school and he was free to write whatever graphic imagery he so desired in his raps. The courts did not feel he ever intended to truly threaten anyone nor do harm to anyone. In short, in this case of off-campus student expression, the school over stepped its bounds in issuing punishment.

All of the above cases led to the courts siding with the students in their decisions. The cases that follow provide a sample of those instances where the courts have found in favor of the schools.

${ }^{183}$ Latour v. Riverside Beaver School District, No. 05-1076, 2005 WL 2106576, (2005). 


\section{Courts Side With Schools}

The case of Jonathan Coy v. Board of Education of the North Canton City Schools was a split decision in essence. In this case a school was supported in punishing a student for accessing a website with a school computer but the court sided with the student in that a section of the code of conduct was unconstitutionally over broad. It is a clear example of how schools need clarification from the courts as to what specifically the parameters for disciplining internet related issues need to be. ${ }^{184}$

Jon Coy created a website outside of school hours on his home computer to promote the exploits of a skateboarding group called NBP. The website contained images of himself and his friends as well as biographical information and quotes attributed to them. There was also a section titled "losers" that contained pictures of three classmates as well as insulting comments about each of the classmates. The most objectionable comment described one boy as being sexually attracted to his mother. The website also contained some profanity, pictures of students giving the finger, and a depressingly high number of grammatical and spelling errors. While crude and juvenile, the website did not contain anything that would be deemed obscene. Several students notified assistant principal Stanley of the website on March 26, 2001. Stanley did nothing at that point.

Jon Coy accessed the website that he created from a school computer during class time when he was supposed to be conducting schoolwork on March 27, 2001. The teacher of the class informed the assistant principal that she believed he had done this. Assistant principal Stanley had the school technology specialist check the computer Coy

\footnotetext{
${ }^{184}$ Jonathan Coy v. Board of Education of the North Canton City Schools, 205 F. Supp. 2d 791, (2002).
} 
was using to determine which sites he had been visiting. The technology specialist informed Stanley that Coy had visited his own, unauthorized website.

The assistant principal met with the school resource officer about the incident. Both agreed to talk to their superiors about the correct action to take. After meeting with their superiors, it was decided that Coy would be suspended for four days and the policy could be investigating the website. The student was also referred to the superintendent for expulsion. A hearing was held and the student was expelled for eighty days. The decision was turned into a probationary term where Coy could stay in school as long as no further problems occurred.

Coy and his parents brought suit for violation of his first and fourteenth amendment rights and because the school code of conduct was overly vague and therefore unconstitutional. The courts found that the school district was within its rights to punish a student for accessing a website from a school computer. The implication from the court seemed to be that in terms of on-campus speech, the facts of this case placed it in the realm of the Tinker case. The question therefore is whether or not a substantial disruption occurred? The court offered, “...no evidence suggests that Coy’s acts in accessing the website had any effect upon the school district's ability to maintain discipline in the school." 185 This creates a bit of a dilemma in interpreting the facts of the case. The court pointed out that summary judgment on all counts could not be granted as it was unclear as to what the student was actually being punished for. The court pointed out that, “...if the school disciplined Coy purely because they did not like what was

\footnotetext{
${ }^{185}$ Jonathan Coy v. Board of Education of the North Canton City Schools, 205 F. Supp. 2d 799, (2002).
} 
contained in his personal website, the plaintiff will prevail."186 In short, the school could discipline a student for accessing an unauthorized site, if that was truly what the discipline was for.

The court also granted partial judgment in favor of Coy in regards to the school policy being overly vague. The court picked apart the school's code of conduct and actually supported the majority of the policy. The part that they found to be unconstitutional was a "catch-all" section numbered 21. Section 21 allowed the school to discipline students for, “... any action or behavior judged by school officials to be inappropriate in a school setting." 187 The court pointed out that section 21 did not give geographical parameters such as at school sponsored events nor did it provide specific examples or guidelines to guide students as to prohibited behavior. In short, it allowed school officials to discipline for anything they deemed inappropriate and thus allowed for potential trampling on student rights.

School administrators can use the Coy case as a guideline in examining the wording of policy as well as the carrying out of such policy. In disciplining a student for inappropriately accessing a website, administrators would do well to ask themselves what exactly the discipline is being levied against, the action or the content of the website. The modern version of firewalls have changed even this scenario in the ten years that have passed from this case, as many sites that are inappropriate can be universally blocked. Unfortunately, the Coy case does not clarify the internet speech issue much for school administrators.

\footnotetext{
${ }^{186}$ Jonathan Coy v. Board of Education of the North Canton City Schools, 205 F. Supp. 2d 805, (2002).

187 Jonathan Coy v. Board of Education of the North Canton City Schools, 205 F. Supp. 2d 810, (2002).
} 
The case of Dylan Mardis v. Hannibal Public School District \#60 was brought when a school suspended and later expelled a student who expressed his desire to kill classmates and possibly himself to a classmate via instant messaging. ${ }^{188}$

Dylan Mardis was a sophomore in the Hannibal School District in October of 2006. While at home on his home computer, he instant messaged to a classmate that he was going to get a gun and kill certain classmates. He also discussed killing himself and making sure his high school was known for something. The classmate notified the school and the authorities. Mardis was taken into custody by police for making the threats and by order of juvenile court was placed in the psychiatric ward of Lakeland Regional Hospital. He was released from Lakeland on the $30^{\text {th }}$ of October and transported to juvenile detention where he remained until February 9, 2007. The school suspended him for ten days on the $31^{\text {st }}$ of October and the superintendent extended that suspension through the end of the school year on November 3. Between the $25^{\text {th }}$ of October and the $4^{\text {th }}$ of November the school administration spent the majority of their time meeting with parents to address their concerns about safety at the school and to know if their children's' names were mentioned in the instant messaging session. Mardis' parents appealed the suspension to the Board of Education, which upheld the suspension. Mardis sued for violation of his first and fourteenth amendment rights.

In deciding this case, the court sided with the school district and addressed the issues of off-campus speech, the Tinker standard, and the "true threat" standard. In each instance, the court felt that the facts of the case supported the actions taken by the school district. In terms of off-campus speech, the court referred to the Tinker case and held that

\footnotetext{
${ }^{188}$ Dylan Mardis v. Hannibal Public School District, No. 10-1428, 2011 WL 3241876, (2011).
} 
any conduct which "...might reasonably have led school authorities to forecast substantial disruption of or material interference with school activities was not immunized by the First Amendment." $" 189$

The court then addressed the Tinker standard and found that the messaging by Mardis not only could have caused a substantial disruption, but actually did so. The principal testified that he "....spoke with 25-30 parents from October $24^{\text {th }}$ to November third and that their primary concerns were whether their children were identified as potential targets and how was the District protecting their children." ${ }^{190}$ Additionally, the school district felt they needed to speed up safety recommendations from the Hannibal Police department concerning school safety, which they did implement due to the incident.

The court also applied the True Threat doctrine in this case. The eighth circuit court defines a true threat as a "....statement that a reasonable recipient would have interpreted as a serious expression of an intent to harm or cause injury to another." ${ }^{191}$ In this episode, not only did the person who first received the threatening message feel it was a genuine statement, but the police also felt so in arresting and detaining the young man. The court further expressed that the facts of this particular case favored the school because, “...combined with his (Mardis) admitted depression, his expressed access to weapons, and his statement that he 'wanted Hannibal to be known for something,' we

\footnotetext{
${ }^{189}$ Dylan Mardis v. Hannibal Public School District, No. 10-1428, 2011 WL 3241892, (2011).

${ }^{190}$ Dylan Mardis v. Hannibal Public School District, No. 10-1428, 2011 WL 3241895, (2011).

${ }^{191}$ Dylan Mardis v. Hannibal Public School District, No. 10-1428, 2011 WL 3241895, (2011).
} 
find no genuine dispute of material fact regarding whether his speech could be reasonably understood as a true threat." ${ }^{192}$

The court found in this case that the Hannibal School system handled the case within their rights. In this instance, the court appears to send the message that student safety is the number one priority when the facts of the case are reasonably threatening. By addressing both the issue of a true threat and applying the Tinker standard, the implication appears to be that an administrator need be certain that the actions taken match the behavior being addressed. If a school feels there is a true threat, they must act accordingly and not simply be using the specter of a true threat to discipline how they desire. When the facts of the case do indeed warrant severe disciplinary action, the court will support schools on all counts. It does not clarify however just were the line is drawn as to when that severe discipline is or is not warranted.

The case of Gregory Requa v. Kent School District No. 415 adds another wrinkle to the off-campus speech issue. Requa was a Junior at Kentridge High School when he videotaped a teacher, edited the raw footage together, added music and graphics, and posted the finished product to Youtube. The finished product included commentary on the teachers' hygiene and organizational habits, as well as footage of a student standing unbeknownst behind the teacher making rabbit ears with two fingers and making pelvic thrust motions while standing behind the teacher. Another segment of the video had a song playing titled "Caution Booty Ahead" and showed several views of the teacher's buttocks as she walked away from the camera. ${ }^{193}$ The video was posted to Youtube over the summer and the school did not become aware of it until the fall of the following

\footnotetext{
${ }^{192}$ Dylan Mardis v. Hannibal Public School District, No. 10-1428, 2011 WL 3241895, (2011).

${ }^{193}$ Gregory Requa v. Kent School District No. 415, 492 F. Supp. 2d 1272, (2007).
} 
school year when a news reporter contacted them. When Requa heard that the reporter had contacted the school, he immediately removed the video. The school principal, Mr. Albrecht, investigated the incident and all parties involved were suspended for 40 days, with 20 of those days held in abeyance if a research paper was written during the suspension. ${ }^{194}$ The reasons for the suspension given included breaking school rules in videotaping the teacher and creating a harassing and intimidating environment by creating the video as well as the general disrespect of the behaviors in the video.

Requa and his family followed the appeal process and the appeal board upheld the suspension. Requa filed suit seeking a temporary restraining order and claiming that he was suspended for posting the video, outside of school and from his own computer, which was protected first amendment speech.

The U.S. District Judge who heard the case sided with the school in this case. She pointed out that, "Here the balance of interests tips in favor of the school district...he (Requa) is not likely to prevail in establishing that the classroom conduct of which he is accused is subject to First Amendment protection." ${ }^{195}$ The judge also explained that basically the classroom activities of videotaping, making pelvic thrusts behind the teacher, and putting two fingers up behind the teachers head like rabbit ears, violated the school sexual harassment code and were enough of a disturbance to warrant the suspension.

In this instance, the activity on school grounds was the determining factor in the school disciplining the student. While the offensive video may have been edited and posted at home, the taping and the activities on the tape were done at school. The school

\footnotetext{
${ }^{194}$ Gregory Requa v. Kent School District No. 415, 492 F. Supp. 2d 1272, (2007).

${ }^{195}$ Gregory Requa v. Kent School District No. 415, 492 F. Supp. 2d 1279, (2007).
} 
district had the decision to suspend this student upheld in large part because they were able to prove that the punishment was based on the on-campus behavior.

The case of Martin Wisniewski v. Board of Education of the Weedsport Central School District addressed the issue of where the boundary for school authority is drawn in the technological world. ${ }^{196}$ Aaron Wisnewski was an $8^{\text {th }}$ grade student who used AOL Instant Messaging to communicate with his friends from his parents' home computer. Aaron's IM icon was a small drawing of a gun firing a bullet into a person's head with blood spattering out. Below the icon appeared the words "Kill Mr. VanderMolen." 197 Mr. VanderMolen was Aaron's English teacher at the time. Aaron created the icon a couple of weeks after the students had been warned that any threats would be treated as acts of violence. The icon was viewed by some 15 friends of Aaron's on AOL while it was available to be viewed during a three week period. During that time, the school Principal found out about the icon, notified the police, and notified Aaron's parents. Aaron admitted making the icon and expressed regret for doing so. Aaron was suspended for five days pending a Superintendent's hearing and was allowed to return after the five days. Mr. VanderMolen requested and was allowed to stop teaching Aaron's class. At the Superintendent's hearing in May, the hearing officer recommended a one semester suspension for threatening a teacher, creating an unsafe environment, and disrupting the school environment. The Board of Education upheld the suspension and Aaron's parents filed suit against the Board of Education for violating his First Amendment freedom of

\footnotetext{
${ }^{196}$ Martin Wisniewski v. Board of Education of the Weedsport Central School District, 494 F.3d 34, (2007).

${ }^{197}$ Martin Wisniewski v. Board of Education of the Weedsport Central School District, 494 F.3d 36, (2007).
} 
expression rights. They also argued that the icon Aaron created was not a "true threat" against the teacher, citing the case of Watts $v$. United States that dealt with such an issue.

The US Court of Appeals for the Second Circuit found in favor of the school district. The Court pointed out that the hearing officer determined the threat was true and therefore it was not protected by the first amendment. The Court also addressed the issue of "true threat" judged against the Watts case by noting, “...although some courts have assessed a student's statements concerning the killing of a school official or a fellow student against the 'true threat' standard of Watts, we think that school officials have significantly broader authority to sanction student speech than Watts allows." 198 Interestingly, here the court specifically states the true threat standard is different for schools. In other cases the courts make a point of threats not rising to true threat levels.

The Court reiterated in Wisniewski that the appropriate First Amendment standard regarding free speech in schools is the case of Tinker v. Des Moines. The Court reaffirmed the notion that schools are allowed to discipline for a disruption or foreseeable disruption of a substantial nature to the school environment. The distinction was also made that “...the fact that Aaron's creation and transmission of the IM icon occurred away from school property does not necessarily insulate him from school discipline."199

The case of Laura Doninger v. Karissa Niehoff, Paula Schwartz dealt with the issue of student free speech. ${ }^{200}$ Avery Doninger was a junior at Lewis Mills High School when she was banned by Principal Karissa Niehoff from running for Senior Class Secretary the

\footnotetext{
${ }^{198}$ Martin Wisniewski v. Board of Education of the Weedsport Central School District, 494 F.3d 44, (2007).

${ }^{199}$ Martin Wisniewski v. Board of Education of the Weedsport Central School District, 494 F.3d 45, (2007).

${ }^{200}$ Laura Doninger v. Karissa Niehoff, Paula Schwartz, No. 09-1452, (2011).
} 
following year, as elections were held in the spring. Doninger was on the student council and was Junior Class Secretary. She and three other student council members were bothered by the possibility that a battle of the bands event potentially would not be held in the new auditorium and had already been rescheduled twice, as the new auditorium was not fully functional and the technical person may have had a scheduling conflict. The student council members responsible for the event were afraid another venue would be less than suitable and that another rescheduling might lead to bands dropping out.

The four student council members, including Doninger, met at the school computer lab, accessed her father's e-mail account, and sent a message to a large number of people requesting that they contact the Superintendent and request that the event not be rescheduled. The e-mail provided Superintendent Schwartz's phone number and was signed by all four students. Both the Principal and Superintendent received an influx of calls as a result of the e-mail. The Principal had to be recalled from an in-service training to address the volume of calls.

Principal Niehoff encountered Doninger in the hall later that day and expressed disappointment that as a member of Student Council she did not act according to the expectations of the position and work with administration to find a suitable resolution rather than sending a mass e-mail. She also explained the e-mail contained false information and that she was in fact amenable to finding an appropriate reschedule date rather than cancelling the battle of the bands event. Principal Niehoff asked Doninger to send out a corrective e-mail. 
That night, Doninger posted a message on her own publicly accessible blog that the battle of the bands had "... been canceled due to douchebags in Central Office."201 The blog also encouraged people to call or e-mail the Principal and Superintendent “...to piss her off more."202 The following morning more calls and e-mails poured in and the battle of the bands was eventually rescheduled on a mutually acceptable date. The blog by Doninger came to light some days later.

Principal Niehoff called Doninger to her office to discuss the blog. She explained that the behavior was not fitting for her position as a class officer and requested that she write an apology to the Superintendent, show a copy of the post to her mother, and withdraw her candidacy for Senior Class Secretary. Doninger complied with the first two requests, but refused on the third. Principal Niehoff effectively banned her from running for office at that point. Doninger's mother sued on the grounds that her Daughter's First Amendment rights had been violated and her Fourteenth Amendment Due Process right had also been violated.

The Court sided with the school on both counts. The court explained that the First Amendment issue was null because, according to the Tinker standard, the school could reasonably believe the conduct would create a risk of substantial disruption within the school environment. The court went further by pointing out that Doninger should have expected the blog to reach school as it “... was purposely designed by Doninger to come onto campus."203 The court also pointed out that schools need not wait for the actual disruption to occur, but that they have a duty to prevent them from occurring in the first

\footnotetext{
${ }^{201}$ Laura Doninger v. Karissa Niehoff, Paula Schwartz, No. 09-1455, (2nd Cir. 2011).

${ }^{202}$ Laura Doninger v. Karissa Niehoff, Paula Schwartz, No. 09-1455, (2nd Cir. 2011).

${ }^{203}$ Laura Doninger v. Karissa Niehoff, Paula Schwartz, No. 09-1459, (2nd Cir. 2011).
} 
place. The court also pointed out the significance of the punishment. The punishment pertained to an extracurricular activity which “...is a privilege that can be rescinded when students fail to comply with the obligations inherent in the activity themselves."204 This also explains why there was no Fourteenth Amendment violation. As shown here, when the behavior carried out via the internet is contrary to the behavior prescribed for a code of conduct for extra-curricular activities, the school is well within its rights to remove the student from participating in the activity.

The case of Kara Kowalski v. Berkeley County Schools came about when a student created a MySpace webpage, off school grounds and outside the school day, about a fellow student. ${ }^{205}$

Kara Kowalski was a senior at Musselman High School in Berkeley County, West Virginia when she created a MySpace webpage titled Students Against Herpes Sluts. Kara invited 100 friends to join this page and roughly 12 high school students did join the group which almost exclusively existed to ridicule fellow student Shay N. Kowalski did not post any comments or photos specifically directed at Shay N., but she did make approving comments on two posts that were derogatory in nature about Shay N. At least one of the photographs uploaded to the webpage was done so from a school computer by Ray Parsons during an after school extra course at 3:40 pm. This photograph depicted Shay N. with the words “enter at your own risk" written across her pelvic area. ${ }^{206}$ Kowalski replied approvingly to this post within minutes, although from home. Shay N. and her parents brought the webpage to the attention of the school district when she

\footnotetext{
${ }^{204}$ Laura Doninger v. Karissa Niehoff, Paula Schwartz, No. 09-1460, (2011).

${ }^{205}$ Kara Kowalski v. Berkeley County Schools, No. 10-1098, (2011).

${ }^{206}$ Kara Kowalski v. Berkeley County Schools, No. 10-1098, (2011).
} 
became aware that it existed. The school district investigated the webpage, interviewed Kowalski and others, and ultimately suspended Kowalski from school for 5 days. Kowalski was also issued a social suspension for 90 days which barred her from participating in cheerleading and a "Charm Review" event.

The US Court of Appeals sided with the school district in this case. The judgment specifically addressed many of the key issues in such cases. In regards to the off-campus speech issue, the court wrote, "There is surely a limit to the scope of a high school's interest in the order, safety, and well-being of its students when the speech at issue originates outside the schoolhouse gates. But we need not fully define that limit here, as we are satisfied that the nexus of Kowalski's speech to Musselman High School's pedagogical interests was sufficiently strong to justify the action taken by school officials in carrying out their role as the trustees of the student body's wellbeing." 207 In short, there was enough of a tie to the school that the school officials were within their rights, and responsibilities, to take action.

The court applied the Tinker Standard to determine if a substantial disruption had taken place to justify the school's action and found that the standard was satisfied. The court decision noted that, “...to be sure, it was foreseeable in this case that Kowalski's conduct would reach the school via computers, smartphones, and other electronic devices given that most of the 'S.A.S.H.' group's members and the target of the group's harassment were Musselman High School students."208 This indicates that school officials do not have to wait for the actual disturbance but need only a reasonable belief that a disturbance may occur, which the court felt they had here.

\footnotetext{
${ }^{207}$ Kara Kowalski v. Berkeley County Schools, No. 10-1115, (2011).

${ }^{208}$ Kara Kowalski v. Berkeley County Schools, No. 10-1115, (2011).
} 
The court did not address the Fraser or true threat standards as they were not applicable to this particular case. The decision did contain the following statement which attempts to address exactly why school officials are allowed more latitude than police in dealing with such issues: "Rather than respond constructively to the school's efforts to bring order and provide a lesson following this incident, Kowalski has rejected those efforts and sued school authorities... Regretfully, she yet fails to see that such harassment and bullying is inappropriate and hurtful and that it must be taken seriously by school administrators in order to preserve an appropriate pedagogical environment. Indeed school administrators are becoming increasingly alarmed by the phenomenon." ${ }^{209}$ This concluding statement confirms the complex and blurry issue that school administrators are faced with.

The case of Christopher Barnet, Kevin Black, and Gary Moses v. Tipton County Board of Education provides yet another wrinkle in the legal fabric of how school officials discipline students for off campus speech. ${ }^{210}$ The courts ultimately sided with the school district, but with a different rationale than many of the cases examined so far.

In October 2006, Christopher Barnett was a student at Brighton High School. He created a fake MySpace page profile of Earl LeFlore, the assistant principal at Brighton HS. The profile contained LeFlore's picture, a biography from the district website, and sexually suggestive comments about female students at Brighton HS. Kevin Black created a similar webpage about Charles Nute, a coach at Brighton HS. Brighton HS first learned of the MySpace profiles when a concerned parent and a newspaper reporter

\footnotetext{
${ }^{209}$ Kara Kowalski v. Berkeley County Schools, No. 10-1116, (2011).

${ }^{210}$ Christopher Barnett, Kevin Black, and Gary Moses v. Tipton County Board of Education, 601 F. Supp. 2d 980, (2009).
} 
contacted the school. The school investigated the websites and discovered that Gary Moses, a student at Brighton HS, contributed to both websites. Moses admitted to contributing to both pages and told school officials that Barnett and Black were the respective authors. The school also discovered that Barnett had accessed the fake MySpace page using a school computer during one of his classes. As a result of the investigation, Barnett received 10 days of suspension, Black received 11 days of suspension, and Moses received 2 days of suspension. Following his suspension, Barnett created a website containing a "wanted" poster of a Brighton HS student that he believed was responsible for telling school officials about the MySpace pages. A hearing was held during the suspension time in which the school heard testimony from Barnett and Black, as well as testimony and evidence from school officials. The school board decided Barnett should be sent to an alternative school while Black's suspension was deemed to be sufficient. The Plaintiffs filed suit for violation of first and fourteenth amendment rights by the school district.

The court granted summary judgment to the school in this case. The courts made mention of the defense that was mounted by the students which was that the WebPages were created as parodies. "Plaintiffs have offered no evidence to support their contention that a visitor to the websites would understand them to be parodies and not describing actual facts. Furthermore, visitors to the fraudulent websites believed it were authentic."211 The court noted that because there was no evidence whatsoever that the websites were parodies, there is no first amendment protection.

\footnotetext{
${ }^{211}$ Christopher Barnett, Kevin Black, and Gary Moses v. Tipton County Board of Education, 601 F. Supp.
} 2d 989, (2009). 
This case was slightly different in that the court addressed the issue of protected speech rather than whether the speech was off-campus or not. The court did not apply the Tinker standard nor the Fraser standard in this case, but rather classified the speech as unprotected in any setting. This case was more black and white in that the speech in question would be illegal in any setting, not just in a school setting. 


\section{CHAPTER V \\ IMPLICATIONS OF CURRENT ISSUES \\ Commonalities and Differences From Rulings}

The cases that have reached the Federal level thus far require some examination to determine commonalities, and more importantly, the differences that led to differing outcomes. While there is no Supreme Court definitive answer as to how schools should proceed in dealing with off-campus internet speech that makes its way on campus, the cases that have been brought do offer some guidelines to work by.

The biggest commonality in the twenty cases that have made it to the Federal Level has been the attempt to use the Tinker v. Des Moines case as the basis by which to judge the current cases. Sixteen of the twenty cases attempted to apply the Tinker standard in some fashion. The results varied in these sixteen cases yet the element of the Tinker standard that was most often utilized to weigh the facts was the material and substantial disruption to the normal school day.

Other standards that were mentioned and applied included the lewd and vulgar language addressed in Fraser, the need for schools to protect pedagogical concerns as described in Morse, as well as the true threat statements laid out in Watts. These were usually addressed as a secondary concern or in conjunction with the notion of disturbing the normal school day.

Another theme to emerge from the court decisions is the concept of school policy having to be clearly defined in terms of actions and consequences. The courts have 
examined cases stemming from the normal school day and stemming from after school hours through a Code of Conduct. In both types of situations, policies that were written as a type of catch all for poor behavior were sometimes found to be too broad, overly vague, and far reaching on the part of the school.

While similarities such as those above might lead to a conclusion that this issue is already settled by applying the Tinker standard, pursuing and documenting cases that substantially disrupt the school day, and writing policy that addresses specific actions within the boundaries of school authority on a normal school day, that is far from the truth of the matter. While the Tinker Standard was clearly the most relied upon case in determining cases, the application of Tinker was far from consistent. The exact definition of what constitutes a material and substantial disruption varied greatly from one circuit court to another. Schools handling similar cases in different circuits could potentially have greatly different outcomes.

Another difference between those cases that resulted in favorable decisions for students, as opposed to those decisions that resulted in favorable decisions for schools, was the accuracy and documentation of the event matching with the discipline that was assigned as a result. In cases where schools documented and demonstrated that the penalty was issued as a result of a threat that they thought to be true, the resulting action needs to demonstrate a heightened level of concern to be upheld. Those cases where it appears that a student is disciplined for saying something unfavorable under the guise of a true threat, or even a disruption, were more likely to be found in favor of the student. 


\section{Table 1 - Case Matrix}

\begin{tabular}{|c|c|c|c|c|}
\hline$C A S E$ & FACTS/ OUTCOME & $\begin{array}{c}\text { STANDARD } \\
\text { APPLIED/ } \\
\text { FINDINGS }\end{array}$ & RATIONALE & IMPLICATIONS \\
\hline $\begin{array}{l}\text { Beussink v. } \\
\text { Woodland R- } \\
\text { IV School } \\
\text { District, 30 F. } \\
\text { Supp. 2nd } \\
1175 \text { (1998). }\end{array}$ & $\begin{array}{l}\text { Student created a webpage } \\
\text { criticizing school \& admin. } \\
\text { Student suspended when } \\
\text { principal found out about } \\
\text { webpage through third party. } \\
\text { Student suspended } 10 \text { days. }\end{array}$ & $\begin{array}{l}\text { Ruling: } \\
\text { Student } \\
\text { Standard: } \\
\text { Tinker }\end{array}$ & $\begin{array}{l}\text { There was no } \\
\text { substantial disruption } \\
\text { to the school day the } \\
\text { language was merely } \\
\text { unfavorable to the } \\
\text { administration. }\end{array}$ & $\begin{array}{l}\text { Schools need to be able } \\
\text { to prove a substantial } \\
\text { disruption or the } \\
\text { likelihood of such a } \\
\text { disruption in order to } \\
\text { discipline. }\end{array}$ \\
\hline $\begin{array}{l}\text { Emmett v. } \\
\text { Kent School } \\
\text { District, 92 F. } \\
\text { Supp. 2d } \\
1088(2000) .\end{array}$ & $\begin{array}{l}\text { Student created an unofficial } \\
\text { webpage for his high school } \\
\text { that included "mock" } \\
\text { obituaries and allowed } \\
\text { visitors to vote on whose } \\
\text { would be next. Student } \\
\text { suspended } 5 \text { days. }\end{array}$ & $\begin{array}{l}\text { Ruling: } \\
\text { Student } \\
\text { Standard: } \\
\text { None }\end{array}$ & $\begin{array}{l}\text { The speech was } \\
\text { entirely off campus } \\
\text { and was clearly not } \\
\text { intended to be a true } \\
\text { threat but rather was } \\
\text { intended as a mock } \\
\text { site. }\end{array}$ & $\begin{array}{c}\text { Schools should be } \\
\text { certain that the speech/ } \\
\text { behavior has impacted } \\
\text { the school if it has not } \\
\text { actually occurred there. } \\
\text { If it is entirely off } \\
\text { campus a school may not } \\
\text { be able to act. }\end{array}$ \\
\hline $\begin{array}{l}\text { Killion v. } \\
\text { Franklin } \\
\text { Regional } \\
\text { School } \\
\text { District, } 136 \\
\text { F. Supp. 2d } \\
446(2001) \text {. }\end{array}$ & $\begin{array}{l}\text { Student created a top ten list } \\
\text { containing derogatory } \\
\text { comments about the AD and } \\
\text { sends it to friends. A third } \\
\text { party brought it to school, } \\
\text { resulting in the creator being } \\
\text { suspended } 10 \text { days. }\end{array}$ & $\begin{array}{l}\text { Ruling: } \\
\text { Student } \\
\text { Standard: } \\
\text { Tinker } \\
\text { (mentions } \\
\text { Fraser) }\end{array}$ & $\begin{array}{l}\text { Found in favor of } \\
\text { student because the } \\
\text { school failed to meet } \\
\text { the substantial } \\
\text { disruption aspect of } \\
\text { Tinker. Mentions the } \\
\text { lewd and derogatory } \\
\text { language of Fraser } \\
\text { but found it does not } \\
\text { apply as the language } \\
\text { occurred at home. }\end{array}$ & $\begin{array}{l}\text { Tinker was applied even } \\
\text { though the creator did } \\
\text { not bring the list to } \\
\text { school. The key element } \\
\text { in this decision again } \\
\text { was the failure of the } \\
\text { school to demonstrate a } \\
\text { substantial disruption no } \\
\text { if it occurred off school } \\
\text { grounds. }\end{array}$ \\
\hline $\begin{array}{l}\text { Coy v. Board } \\
\text { of Education } \\
\text { of the North } \\
\text { Canton City } \\
\text { Schools, 205 } \\
\text { F. Supp. 2d } \\
791(2002) \text {. }\end{array}$ & $\begin{array}{l}\text { Student created a website } \\
\text { criticizing fellow students and } \\
\text { describing them as losers. He } \\
\text { then accessed the website at } \\
\text { school. Student was } \\
\text { suspended for } 4 \text { days and put } \\
\text { on probation for } 80 .\end{array}$ & $\begin{array}{l}\text { Ruling: } \\
\text { Student } \\
\text { Standard: } \\
\text { Tinker }\end{array}$ & $\begin{array}{l}\text { Again applied the } \\
\text { substantial disruption } \\
\text { test of Tinker and } \\
\text { found the school had } \\
\text { not demonstrated } \\
\text { such a disruption. } \\
\text { Court also discussed } \\
\text { that one particular } \\
\text { school policy that } \\
\text { allowed the school to } \\
\text { punish for undefined } \\
\text { inappropriate action } \\
\text { was overly vague and } \\
\text { unconstitutional. }\end{array}$ & $\begin{array}{c}\text { Schools must be able to } \\
\text { document a substantial } \\
\text { disruption or likelihood } \\
\text { of such a disruption. In } \\
\text { creating policy schools } \\
\text { should also take notice } \\
\text { of the unconstitutional } \\
\text { finding for catch-all } \\
\text { policies. }\end{array}$ \\
\hline $\begin{array}{c}\text { Mahaffey v. } \\
\text { Aldrich, } 236 \\
\text { F. Supp. 2d } \\
779(2002) .\end{array}$ & $\begin{array}{l}\text { Student created a website in a } \\
\text { joking manner that listed } \\
\text { fellow students that he wished } \\
\text { would die. Student } \\
\text { suspended but not expelled } \\
\text { for most of the semester. }\end{array}$ & $\begin{array}{c}\text { Ruling: } \\
\text { Student } \\
\text { Standard: } \\
\text { None }\end{array}$ & $\begin{array}{l}\text { Court declared that } \\
\text { Tinker does not apply } \\
\text { as the speech was off } \\
\text { campus. The speech } \\
\text { was also not a true } \\
\text { threat as no } \\
\text { reasonable person } \\
\text { would think the } \\
\text { author actually } \\
\text { wanted to kill the } \\
\text { people listed. }\end{array}$ & $\begin{array}{l}\text { Schools must be certain } \\
\text { that it is in fact a school } \\
\text { issue before doling out } \\
\text { discipline. Offensive } \\
\text { statements made at home } \\
\text { are not enough. If the } \\
\text { speech is thought to be } \\
\text { an actual threat school } \\
\text { actions should reflect } \\
\text { that and include law } \\
\text { enforcement. }\end{array}$ \\
\hline
\end{tabular}




\begin{tabular}{|c|c|c|c|c|}
\hline $\begin{array}{l}\text { J.S. v. } \\
\text { Bethlehem } \\
\text { Area School } \\
\text { District, } 807 \\
\text { A. } 2 \text { d } 847 \\
\text { (2002) }\end{array}$ & $\begin{array}{l}\text { Student created a website that } \\
\text { targeted the principal and a } \\
\text { teacher. The teacher took a } \\
\text { leave of absence due to the } \\
\text { stress. Student suspended } 10 \\
\text { days then expelled. }\end{array}$ & $\begin{array}{l}\text { Ruling: } \\
\text { School } \\
\text { Standard: } \\
\text { Tinker }\end{array}$ & $\begin{array}{l}\text { Court declared that } \\
\text { even though the } \\
\text { speech occurred off- } \\
\text { campus, it was aimed } \\
\text { exclusively at the } \\
\text { school and } \\
\text { completely disrupted } \\
\text { the school } \\
\text { environment. Court } \\
\text { also made mention } \\
\text { that such a disruption } \\
\text { need not actually } \\
\text { occur, but school only } \\
\text { need reason to believe } \\
\text { that such a disruption } \\
\text { was likely to occur. }\end{array}$ & $\begin{array}{l}\text { Schools that demonstrate } \\
\text { a substantial disruption } \\
\text { have a far better chance } \\
\text { of prevailing on } \\
\text { judgment. }\end{array}$ \\
\hline $\begin{array}{l}\text { Flaherty v. } \\
\text { Keystone } \\
\text { Oaks School } \\
\text { District, 247 } \\
\text { F. Supp. 2d } \\
698(2003) \text {. }\end{array}$ & $\begin{array}{l}\text { Student posted negative } \\
\text { internet messages about the } \\
\text { boy's volleyball team. He } \\
\text { was punished according to the } \\
\text { student handbook. }\end{array}$ & $\begin{array}{l}\text { Ruling: } \\
\text { Student } \\
\text { Standard: } \\
\text { Tinker }\end{array}$ & $\begin{array}{l}\text { This case did not } \\
\text { touch on the issue of } \\
\text { off-campus speech } \\
\text { but rather applied the } \\
\text { substantial disruption } \\
\text { element of Tinker. } \\
\text { The court found the } \\
\text { schools simply did } \\
\text { not demonstrate a } \\
\text { substantial disruption. } \\
\text { Court also mentioned } \\
\text { overbroad and vague } \\
\text { policies in this case. }\end{array}$ & $\begin{array}{c}\text { Schools must } \\
\text { demonstrate the } \\
\text { substantial disruption } \\
\text { criteria has been met to } \\
\text { punish. Court in this } \\
\text { case also mentioned that } \\
\text { policies are overbroad if } \\
\text { they are not connected to } \\
\text { actions that meet this } \\
\text { Tinker standard. Court } \\
\text { also stated a policy is } \\
\text { vague if it does not give } \\
\text { students adequate } \\
\text { warning of the behavior } \\
\text { that could be punished. } \\
\text { Again, the catch-all } \\
\text { policies are questionable. }\end{array}$ \\
\hline $\begin{array}{l}\text { Neal v. Efurd, } \\
\text { No.04-2195 } \\
(2005) .\end{array}$ & $\begin{array}{l}\text { Two students created } \\
\text { websites critical of their } \\
\text { school. One was more severe } \\
\text { than the other. Neither was } \\
\text { accessed at school. Both } \\
\text { suspended } 3 \text { days when sites } \\
\text { were brought to the } \\
\text { principal's attention by } \\
\text { concerned students and } \\
\text { teachers. }\end{array}$ & $\begin{array}{l}\text { Ruling: } \\
\text { Student } \\
\text { Standard: } \\
\text { Tinker }\end{array}$ & $\begin{array}{l}\text { Court found that there } \\
\text { was no substantial } \\
\text { disruption to the } \\
\text { school. In fact, } \\
\text { unfounded } \\
\text { apprehensions by } \\
\text { some people involved } \\
\text { did not create a } \\
\text { reasonable likelihood } \\
\text { of substantial } \\
\text { disruption. }\end{array}$ & $\begin{array}{l}\text { Schools should tread } \\
\text { lightly when dealing } \\
\text { with complaints brought } \\
\text { to them by concerned } \\
\text { parents, students, and } \\
\text { staff. This provides an } \\
\text { interesting contrast to } \\
\text { bullying and harassment } \\
\text { issues that circulate in } \\
\text { the media currently. }\end{array}$ \\
\hline
\end{tabular}




\begin{tabular}{|c|c|c|c|c|}
\hline $\begin{array}{l}\text { Latour v. } \\
\text { Riverside } \\
\text { Beaver } \\
\text { School } \\
\text { District, No. } \\
\text { 05-1076 } \\
(2005) .\end{array}$ & $\begin{array}{l}\text { Student wrote four rap songs } \\
\text { that were published on the } \\
\text { internet. One was about a } \\
\text { fellow student who moved as } \\
\text { a result of the comments. } \\
\text { The remaining three had } \\
\text { violent themes. Student was } \\
\text { suspended. }\end{array}$ & $\begin{array}{c}\text { Ruling: } \\
\text { Student } \\
\text { Standard: } \\
\text { Tinker }\end{array}$ & $\begin{array}{l}\text { Court found that there } \\
\text { was no substantial } \\
\text { disruption even though } \\
\text { a fellow student felt the } \\
\text { need to switch schools. } \\
\text { Court also mentioned } \\
\text { that the fact that the } \\
\text { student had no history } \\
\text { of violence the students } \\
\text { mentioned did not feel } \\
\text { threatened and if the } \\
\text { school did not treat the } \\
\text { matter as if the student } \\
\text { threatened someone it } \\
\text { could not be taken as a } \\
\text { true threat. }\end{array}$ & $\begin{array}{l}\text { Schools must } \\
\text { demonstrate a substantial } \\
\text { disruption. If a school is } \\
\text { going to take action as if } \\
\text { a true threat were made } \\
\text { their actions should } \\
\text { reflect that by including } \\
\text { law enforcement } \\
\text { suggesting counseling or } \\
\text { taking other action to } \\
\text { reflect the serious nature } \\
\text { of a threat. }\end{array}$ \\
\hline $\begin{array}{c}\text { Requa v. } \\
\text { Kent School } \\
\text { District, } 492 \\
\text { F. Supp. 2d } \\
1272 \text { (2007). }\end{array}$ & $\begin{array}{l}\text { Student videotaped his } \\
\text { teacher at school with a } \\
\text { fellow student behind her } \\
\text { making pelvic thrusts and } \\
\text { giving bunny ears. Video } \\
\text { was posted on YouTube. } \\
\text { School became aware when a } \\
\text { news station called asking for } \\
\text { comment. Students involved } \\
\text { were given } 40 \text { day } \\
\text { suspensions with opportunity } \\
\text { to reduce to } 20 \text {. }\end{array}$ & $\begin{array}{c}\text { Ruling: } \\
\text { School } \\
\text { Standard: } \\
\text { Fraser }\end{array}$ & $\begin{array}{l}\text { Court stated that } \\
\text { school showed the } \\
\text { discipline was for the } \\
\text { lewd behavior in class } \\
\text { and not for the off- } \\
\text { campus posting of the } \\
\text { video. }\end{array}$ & $\begin{array}{l}\text { Schools maintain the } \\
\text { right to discipline for in } \\
\text { class behavior. The off- } \\
\text { campus speech twist of } \\
\text { this case does not negate } \\
\text { that right if the school } \\
\text { can demonstrate that the } \\
\text { discipline is for the in } \\
\text { class behavior. }\end{array}$ \\
\hline $\begin{array}{c}\text { Wisniewski } \\
\mathrm{v} \text {. Board of } \\
\text { Education of } \\
\text { the } \\
\text { Weedsport } \\
\text { Central } \\
\text { School } \\
\text { District, } 494 \\
\text { F. 3d 34 } \\
\text { (2007). }\end{array}$ & $\begin{array}{l}\text { Student created an instant } \\
\text { message icon that showed a } \\
\text { gun shooting his teacher. The } \\
\text { teacher refused to teach the } \\
\text { class with that student. } \\
\text { Student was suspended for } 5 \\
\text { days and had a hearing in that } \\
\text { time. At the hearing, school } \\
\text { called the icon a true threat } \\
\text { and suspended student for a } \\
\text { semester. }\end{array}$ & $\begin{array}{c}\text { Ruling: } \\
\text { School } \\
\text { Standard: } \\
\text { Tinker }\end{array}$ & $\begin{array}{l}\text { Court found that even } \\
\text { though the speech } \\
\text { was completely away } \\
\text { from school, it could } \\
\text { reasonably be thought } \\
\text { to create a substantial } \\
\text { disruption at school } \\
\text { when it was brought } \\
\text { to the attention of the } \\
\text { school. Court also } \\
\text { makes mention that } \\
\text { schools have broader } \\
\text { discretion than the } \\
\text { authorities would } \\
\text { have in dealing with a } \\
\text { true threat case. }\end{array}$ & $\begin{array}{l}\text { This finding and } \\
\text { rationale seem to go } \\
\text { against the above rulings } \\
\text { in what a school needs to } \\
\text { demonstrate in showing } \\
\text { a reasonable expectation } \\
\text { of substantial disruption. }\end{array}$ \\
\hline
\end{tabular}




\begin{tabular}{|c|c|c|c|c|}
\hline $\begin{array}{l}\text { Barnett v. } \\
\text { Tipton } \\
\text { County Board } \\
\text { of Education, } \\
\text { 601 F. Supp. } \\
\text { 2d 980 } \\
\text { (2009). }\end{array}$ & $\begin{array}{l}\text { Three students were involved } \\
\text { in making fake MySpace } \\
\text { pages for staff members with } \\
\text { pictures biographies and } \\
\text { inappropriate comments } \\
\text { about female students. All } \\
\text { three received in-school } \\
\text { suspensions for the websites. } \\
\text { One student then made a } \\
\text { wanted poster of a fellow } \\
\text { student he thought reported } \\
\text { him to the administration. } \\
\text { The student who created the } \\
\text { wanted poster was sent to an } \\
\text { alternative school and the } \\
\text { remaining students would } \\
\text { fulfill the in-school } \\
\text { suspensions when a hearing } \\
\text { was held on the matter. }\end{array}$ & $\begin{array}{l}\text { Ruling: } \\
\text { School } \\
\text { Standard: } \\
\text { None }\end{array}$ & $\begin{array}{l}\text { Court found in favor } \\
\text { of the school because } \\
\text { the student did not } \\
\text { demonstrate any } \\
\text { wrong-doing by the } \\
\text { school in terms of } \\
\text { First or Fourteenth } \\
\text { Amendments. The } \\
\text { students claimed that } \\
\text { the websites were } \\
\text { parodies but the court } \\
\text { found that a person } \\
\text { visiting the sites } \\
\text { would think the staff } \\
\text { members were } \\
\text { engaged in wrong- } \\
\text { doing and not that } \\
\text { they were parodies. }\end{array}$ & $\begin{array}{l}\text { The court in this case did } \\
\text { not touch on the off- } \\
\text { campus nature of the } \\
\text { speech and did not } \\
\text { address the Tinker } \\
\text { standard, but rather held } \\
\text { that the students did not } \\
\text { demonstrate that their } \\
\text { rights were violated. }\end{array}$ \\
\hline $\begin{array}{c}\text { Evans v. } \\
\text { Bayer, 684 F. } \\
\text { Supp. 2d } \\
1365(2010) .\end{array}$ & $\begin{array}{c}\text { Student created a Facebook } \\
\text { group about her dislike for a } \\
\text { teacher. After she removed it, } \\
\text { it was brought to the attention } \\
\text { of the principal and the } \\
\text { student was suspended for } 3 \\
\text { days. She was also moved } \\
\text { from an AP class to an honors } \\
\text { class. }\end{array}$ & $\begin{array}{l}\text { Ruling: } \\
\text { Student } \\
\text { Standard: } \\
\text { Tinker } \\
\text { (mention } \\
\text { Fraser and } \\
\text { Morse) }\end{array}$ & $\begin{array}{l}\text { Court found that the } \\
\text { school did not } \\
\text { demonstrate a } \\
\text { reasonable belief that } \\
\text { a substantial } \\
\text { disruption would } \\
\text { occur due to the off- } \\
\text { campus speech. In } \\
\text { fact the school was } \\
\text { not even aware of the } \\
\text { speech until after it } \\
\text { was removed. } \\
\text { Interestingly the court } \\
\text { mentioned that the } \\
\text { language did not } \\
\text { satisfy the description } \\
\text { of lewd found in } \\
\text { Fraser nor did it } \\
\text { undermine the } \\
\text { fundamental values of } \\
\text { the school like Morse. }\end{array}$ & $\begin{array}{l}\text { The Tinker standard of } \\
\text { substantial disruption } \\
\text { must be present to } \\
\text { discipline. This case } \\
\text { does open the door for } \\
\text { disciplining for off- } \\
\text { campus speech that } \\
\text { undermines the } \\
\text { fundamental values of } \\
\text { the school, as in the } \\
\text { Morse case. }\end{array}$ \\
\hline
\end{tabular}




\begin{tabular}{|c|c|c|c|c|}
\hline $\begin{array}{c}\text { J.C. v. } \\
\text { Beverly Hills } \\
\text { Unified } \\
\text { School } \\
\text { District, } 711 \\
\text { F. Supp. 2d } \\
\text { 1094 (2010). }\end{array}$ & $\begin{array}{l}\text { Student posted a YouTube } \\
\text { video of students making } \\
\text { hurtful comments about a } \\
\text { classmate. Student who } \\
\text { posted the video was } \\
\text { suspended for } 2 \text { days. }\end{array}$ & $\begin{array}{c}\text { Ruling: } \\
\text { Student } \\
\text { Standard: } \\
\text { Tinker }\end{array}$ & $\begin{array}{l}\text { Court found that the } \\
\text { Tinker standard was } \\
\text { not met on two levels } \\
\text { with the first being } \\
\text { there was no evidence } \\
\text { of a substantial } \\
\text { disruption. The court } \\
\text { went so far as to say } \\
\text { the school did not } \\
\text { show that the } \\
\text { administrators had to } \\
\text { alter their normal } \\
\text { routine in any way. } \\
\text { Additionally the } \\
\text { language in Tinker } \\
\text { that allows for } \\
\text { regulation of speech } \\
\text { if it interferes with } \\
\text { other students' rights } \\
\text { to be secure was not } \\
\text { met. }\end{array}$ & $\begin{array}{l}\text { Schools should tread } \\
\text { lightly when a clear } \\
\text { substantial disruption is } \\
\text { not present. This needs } \\
\text { to be weighed against } \\
\text { bullying and harassment } \\
\text { standards in such cases. }\end{array}$ \\
\hline $\begin{array}{c}\text { Donniger v. } \\
\text { Niehoff, } 527 \\
\text { F. 3d } 31 \\
(2008)\end{array}$ & $\begin{array}{l}\text { Student criticized } \\
\text { administration for } \\
\text { rescheduling an event and } \\
\text { called them "douche bags." } \\
\text { Called on other students to } \\
\text { contact the administration } \\
\text { about the event. Student was } \\
\text { banned from running for } \\
\text { student council the following } \\
\text { year. }\end{array}$ & $\begin{array}{l}\text { Ruling: } \\
\text { School } \\
\text { Standard: } \\
\text { Tinker }\end{array}$ & $\begin{array}{l}\text { Court upheld that a } \\
\text { substantial disruption } \\
\text { did in fact occur as } \\
\text { numerous phone calls } \\
\text { reached the school } \\
\text { regarding the } \\
\text { rescheduled event } \\
\text { after Donniger's } \\
\text { actions. Court made } \\
\text { mention that } \\
\text { punishment may not } \\
\text { fit the crime, but the } \\
\text { court was not going to } \\
\text { undermine schools } \\
\text { without specific } \\
\text { constitutional } \\
\text { violations. }\end{array}$ & $\begin{array}{l}\text { Schools must rely on the } \\
\text { substantial disruption } \\
\text { element of Tinker, even } \\
\text { when uncertain. The } \\
\text { court here seems to err in } \\
\text { favor of schools when no } \\
\text { constitutional offenses } \\
\text { have occurred, unlike } \\
\text { some cases above. }\end{array}$ \\
\hline $\begin{array}{l}\text { J.S. v. Blue } \\
\text { Mountain } \\
\text { School } \\
\text { District, no. } \\
08-4138, \\
2011 \mathrm{WL} \\
2305973 \\
(2011) .\end{array}$ & $\begin{array}{l}\text { Student created a fake } \\
\text { MySpace page about the } \\
\text { principal which personally } \\
\text { attacked the principal in a } \\
\text { shameful nature. Student } \\
\text { allowed another student to } \\
\text { access the site at school and } \\
\text { was suspended } 10 \text { days. } \\
\text { During the course of the trial } \\
\text { the school conceded there } \\
\text { was not a substantial } \\
\text { disruption to the school } \\
\text { environment. }\end{array}$ & $\begin{array}{l}\text { Ruling: } \\
\text { Student } \\
\text { Standard: } \\
\text { Tinker } \\
\text { (mentions } \\
\text { Fraser and } \\
\text { Morse) }\end{array}$ & $\begin{array}{l}\text { Court pointed out that } \\
\text { the school's } \\
\text { recognition that there } \\
\text { was no substantial } \\
\text { disruption left no } \\
\text { grounds for discipline } \\
\text { to be issued. The } \\
\text { point that if black } \\
\text { armbands of Tinker } \\
\text { were not grounds for } \\
\text { discipline then neither } \\
\text { were the facts of this } \\
\text { case. The principal } \\
\text { disciplined only } \\
\text { because the language } \\
\text { was disagreeable. }\end{array}$ & $\begin{array}{l}\text { Schools must meet the } \\
\text { substantial disruption } \\
\text { standard of Tinker. } \\
\text { Court mentions Fraser } \\
\text { and Morse even though } \\
\text { the facts of this case do } \\
\text { not directly relate to } \\
\text { those cases. }\end{array}$ \\
\hline
\end{tabular}




\begin{tabular}{|c|c|c|c|c|}
\hline $\begin{array}{l}\text { Layshock v. } \\
\text { Hermitage } \\
\text { School } \\
\text { District, No. } \\
07-4465, \\
2011 \mathrm{WL} \\
2305970 \\
(2011) .\end{array}$ & $\begin{array}{l}\text { Student created a fake } \\
\text { MySpace page about the } \\
\text { principal that was insulting } \\
\text { but not threatening. Student } \\
\text { was suspended } 10 \text { days, } \\
\text { removed from honors classes } \\
\text { and placed in an alternative } \\
\text { program, and banned from } \\
\text { any extracurricular } \\
\text { participation including } \\
\text { graduation. }\end{array}$ & $\begin{array}{l}\text { Ruling: } \\
\text { Student } \\
\text { Standard: } \\
\text { Tinker } \\
\text { (mentions } \\
\text { Fraser) }\end{array}$ & $\begin{array}{l}\text { Court points out that } \\
\text { there was no } \\
\text { substantial disruption } \\
\text { to the school so the } \\
\text { speech essentially is } \\
\text { off-campus speech. } \\
\text { Other standards do } \\
\text { not apply to off- } \\
\text { campus speech. }\end{array}$ & $\begin{array}{l}\text { Schools must meet the } \\
\text { substantial disruption } \\
\text { test of Tinker to } \\
\text { discipline. Fraser again } \\
\text { referenced though not } \\
\text { applied. }\end{array}$ \\
\hline $\begin{array}{l}\text { Kowalski v. } \\
\text { Berkeley } \\
\text { County } \\
\text { Schools, No. } \\
10-1098, \\
2011 \mathrm{WL} \\
3132523 \\
(2011)\end{array}$ & $\begin{array}{l}\text { Student created a MySpace } \\
\text { page that ridiculed one } \\
\text { particular classmate and } \\
\text { suggested that another } \\
\text { classmate had an STD. } \\
\text { Student was suspended for } 5 \\
\text { days and received a } 90 \text { day } \\
\text { social suspension. }\end{array}$ & $\begin{array}{c}\text { Ruling: } \\
\text { School } \\
\text { Standard: } \\
\text { Tinker }\end{array}$ & $\begin{array}{l}\text { Court found the } \\
\text { student speech to be } \\
\text { outside the protection } \\
\text { of the First } \\
\text { Amendment and not } \\
\text { the type of speech the } \\
\text { educational system } \\
\text { had to tolerate. } \\
\text { School system was } \\
\text { within their bounds as } \\
\text { trustees of student } \\
\text { body's well-being in } \\
\text { issuing discipline to } \\
\text { protect other students. }\end{array}$ & $\begin{array}{l}\text { While the continuing } \\
\text { theme of using the } \\
\text { Tinker standard was } \\
\text { active in this case, it was } \\
\text { applied much more } \\
\text { generously in the } \\
\text { school's favor than other } \\
\text { cases. Court actually } \\
\text { used terms bullying and } \\
\text { harassment in describing } \\
\text { why the student behavior } \\
\text { was wrong. }\end{array}$ \\
\hline $\begin{array}{l}\text { Mardis v. } \\
\text { Hannibal } \\
\text { Public School } \\
\text { District, No. } \\
\text { 10-1428, } \\
2011 \text { WL } \\
3241876 \\
\text { (2011). }\end{array}$ & $\begin{array}{l}\text { Student sent IM to classmate } \\
\text { that he was going to get a gun } \\
\text { and kill several classmates } \\
\text { and wanted to make sure the } \\
\text { school was known for } \\
\text { something. Student was } \\
\text { taken into custody placed in } \\
\text { juvenile detention and then } \\
\text { into a psychiatric hospital. } \\
\text { Student was suspended from } \\
\text { school until the end of the } \\
\text { school year. }\end{array}$ & $\begin{array}{c}\text { Ruling: } \\
\text { School } \\
\text { Standard: } \\
\text { Watts (true } \\
\text { threat) \& } \\
\text { Tinker }\end{array}$ & $\begin{array}{l}\text { Court first found that } \\
\text { the speech was a true } \\
\text { threat and therefore } \\
\text { not protected First } \\
\text { Amendment Speech. } \\
\text { Secondly the schools } \\
\text { could step in and } \\
\text { issue discipline } \\
\text { because the } \\
\text { statements } \\
\text { substantially } \\
\text { disrupted the school } \\
\text { environment. }\end{array}$ & $\begin{array}{l}\text { The school included law } \\
\text { enforcement from the } \\
\text { beginning and treated the } \\
\text { comments as if they } \\
\text { were going to be carried } \\
\text { out. This is important if } \\
\text { a school administrator } \\
\text { believes they are in fact } \\
\text { a true threat. The court } \\
\text { here again uses Tinker in } \\
\text { a more school-supportive } \\
\text { manner in defining what } \\
\text { exactly a substantial } \\
\text { disruption is. }\end{array}$ \\
\hline $\begin{array}{l}\text { TV ex rel BV } \\
\text { v. Smith- } \\
\text { Green } \\
\text { Community } \\
\text { School } \\
\text { Corporation, } \\
\text { No. 1:09-CV- } \\
\text { 290-PPS, } \\
\text { 2011 WL } \\
\text { 3501698 } \\
\text { (2011). }\end{array}$ & $\begin{array}{l}\text { Two students took pictures of } \\
\text { themselves pretending to suck } \\
\text { phallic shaped suckers in } \\
\text { various poses and posted the } \\
\text { images to social media } \\
\text { websites. A parent brought } \\
\text { the images to the } \\
\text { superintendent's attention and } \\
\text { stated the pictures were } \\
\text { causing problems on the } \\
\text { volleyball team. The two } \\
\text { girls were suspended } 25 \% \text { of } \\
\text { the season under the } \\
\text { extracurricular code of } \\
\text { conduct. }\end{array}$ & $\begin{array}{c}\text { Ruling: } \\
\text { Student } \\
\text { Standard: } \\
\text { Tinker }\end{array}$ & $\begin{array}{l}\text { Court found in favor } \\
\text { of the student since } \\
\text { the only disruption } \\
\text { was some arguing } \\
\text { between } 15 \text { year olds } \\
\text { at practice and an } \\
\text { upset parent. Court } \\
\text { pointed out that the } \\
\text { code of conduct } \\
\text { provision that } \\
\text { addressed this issue } \\
\text { was overly vague as it } \\
\text { did not describe what } \\
\text { actions would be } \\
\text { problematic. }\end{array}$ & $\begin{array}{l}\text { This case is the first to } \\
\text { challenge the code of } \\
\text { conduct penalties and } \\
\text { not the actual academic } \\
\text { day penalties for off- } \\
\text { campus speech. } \\
\text { Administrators must note } \\
\text { that Tinker still applies } \\
\text { to the code of conduct. }\end{array}$ \\
\hline
\end{tabular}




\section{Guidelines to Consider - Administrative Practice}

While there is no substitute for a Supreme Court ruling on the matter, there are some guidelines that practicing administrators can utilize when dealing with an offcampus internet speech issue that makes its way on campus. As the cases to date have demonstrated, the Tinker Standard must be utilized early in the process in deciding whether to deal with an issue. It is also important for administrators to document the process as one of these cases develops in their school, as the specific factors in handling such a case could potentially cause it to end up in court.

Administrators should, of course, consult district leadership and legal counsel in dealing with these issues when matters call for such actions. The reference tool on the bottom of this page provides a series of questions, based on the cases dealing with speech, and student speech in particular, that have gone to the Supreme Court. While not a checklist to quickly go through, the reference tool should guide administrative questions in deciding to take up a particular issue or not.

\section{Table 2 - Administrative Consideration Tool} A) Did the speech occur at school, did it originate using school technology, or was it transmitted via school technology?
No $\rightarrow$ See (C)
Yes $->$ Discipline accordingly

\section{B) Contact Law enforcement}

C) Follow prescription of Code of Conduct if behavior falls under those guidelines.

Was the speech protected speech? Did the speaker:
1) Communicate a serious expression of intent to commit an act of unlawful violence to a person or group?
2) Use words that by their very utterance inflict injury or tend to incite an immediate reaction?
3) Offer to engage in illegal transactions?
4) Define sexual activity in an offensive way or in a manner lacking artistic, scientific, artistic, or political value?
5) Use speech containing sexually explicit visual portrayals of children?


2) Contact law enforcement for clarification.

No $->$ Proceed to next level

Yes $->$ See $(A)$ and $(B)$ above

Does the speech pass the Tinker standard - part I? Did/was the speech:

1) Originate at school?

2) Transmitted or accessed at school or using a school computer?

3) Occur due to or involve some connection, or nexus, to the school?

No -> Proceed to next level

Yes -> Discipline accordingly

Did the speech occur via a school activity or in conjunction w/ other pedagogical concerns, such as but not limited to:

1) School-Sponsored Newspaper

2) School-Sponsored TV

3) School-Sponsored Website/ blog/ etc.

No -> Proceed to next level

Yes -> Discipline accordingly

Does the speech pass the Tinker standard - part II? Did(could) the speech:

1) Cause a material or substantial disruption to the normal operation of school?

2) Potentially create a material or substantial disruption to the normal operation of school?

No -> Proceed to next level

Yes -> Discipline accordingly

Does the speech expose students to language that is:

1) Inappropriate

2) Illegal

3) Referencing use of drugs or similarly harmful activities

No $->$ Proceed to next level

Yes -> Discipline accordingly

Did the speech result in students being exposed to the following?

1) Sexually explicit speech

2) Lewd speech

3) Indecent speech

No -> Proceed to next level

Yes -> Discipline accordingly

Did the speech involve:

1) A student involved in an extracurricular activity

2) A student that had signed a code of conduct agreement

3) Was such that it violated the behavior described in the code of conduct agreement

No $->$ Proceed to next level

Yes $\rightarrow$ See $(C)$ above

DO NOT PURSUE UNDER CURRENT CIRCUMSTANCES 


\section{Administrative Practice - Policy}

While the legal cases are being handled in a judicial setting, the issue of offcampus internet speech eliciting action from the school is also an educational issue. As schools have evolved they have been required to do more for students and educating students about the world in which they live has been one of those tasks. The U.S Department of Education Office for Civil Rights went so far as to issue a Dear Colleague Letter to make educators aware of the issue of harassment and bullying, including cyberbullying. ${ }^{212}$ This letter addressed the more widespread issue of bullying and explained that schools do have an avenue for dealing with student internet speech if it rises to the level of harassment. Unfortunately, the line has not clearly drawn as the courts are divided on how severe speech must be to reach an unacceptable level. The case of LaTour v. Riverside Beaver School District demonstrated this, as a female student actually transferred schools as a result of a male student making comments about her in a rap song. The court that heard the case did not feel there was enough of a disturbance to support the discipline of the male student who made the comments. ${ }^{213}$

The Religious Freedom Education Project/ First Amendment Center produced an online guide for educators titled Harassment, Bullying, and Free Expression. The guide recognized and mentioned, though not by name, the Tinker standard and discipline issues associated with internet speech. The guide stated that schools should nonetheless “...consider incorporating proactive measures as part of their response apart from

\footnotetext{
${ }^{212}$ U.S. Department of Education Office for Civil Rights, Dear Colleague Letter, October 26, 2010.

${ }^{213}$ Latour v. Riverside Beaver School District, No. 05-1076, 2005 WL 2106576, (2005).
} 
discipline and suppression of speech." 214 The document also had the notice that it is not legal advice but rather suggestions of good citizenship education.

While policy alone has not been enough to address student behavior in the absence of a legal precedent, that does not mean that policy should be ignored. Laura Hemmer writing in the Illinois School Board Journal addressed the issue from two perspectives. While recognizing the discipline limitations of internet speech as the first perspective, she pointed out from a policy perspective that all schools receiving Federal dollars, through the No Child Left Behind Act, are required to have a policy on Internet safety as well as protections in place to prevent minors from accessing obscene and inappropriate visual images and content. ${ }^{215}$ What most schools have minimally in place are a firewall or web filtering program and an Acceptable Usage Policy, or AUP. An AUP spells out to students, parents, and school personnel what exactly school computers can or cannot be used for. Hemmer suggested that many districts in Illinois go beyond the minimum in regards to dealing with student speech by banning social networking sites entirely, which is allowed. Hemmer also suggested that state laws be checked for consistency with any policy.

The Federal Government has not created anti-bullying laws at their level, Secretary of Education Arne Duncan did issue a resource for those state or local agencies writing law or policy to address bullying. While not specifically dealing with off-campus internet speech, it does provide a framework from which educators may begin to address the issue. Arne Duncan's suggestions were posted through www.stopbullying.gov and

\footnotetext{
${ }^{214}$ Religious Freedom Education Project/ First Amendment Center, Harassment, Bullying, and Free Expression, p.8, retrieved on July 1, 2013. Retrieved from: www.religiousfreedomeducation.org ${ }^{215}$ Laura Hemmer. "MySpace, SchoolSpace: Is Your Computer Safe?" Illinois School Board Journal. Retrieved online July 1, 2013. Retrieved from: http://www.iasb.com/journal/j091008_08.cfm.
} 
contained 11 Key Components in State Anti-Bullying Laws. ${ }^{216}$ Duncan addressed the guidelines to State and local educational agencies and did recommend checking with state and local laws before finalizing any policies.

Administrators would be wise to consult state laws in writing the specifics of an AUP as the details are state specific. Sameer Hinduja and Justin W. Patchin maintain a list of current and proposed State Cyberbullying Laws and Policies through the Cyberbullying Research Center. ${ }^{217}$ As of July 2013, 49 States had bullying laws on the books with Montana being the lone exception. Of those states, 19 specifically mentioned cyberbullying in the law. The Cyberbullying Research Center went so far as to include language, or actual electronic links, to the specific laws or codes addressing the issue in each state.

\section{Implications}

The issue of off-campus internet speech making its way onto campus is the new version of an age old problem. Technology has changed the nature of how students interact and communicate, but it has not changed the fact that students interact and sometimes poor choices are made in those interactions. As our public school system has developed and grown through our history, the societal views of what schools have been expected to provide have evolved. The founding fathers envisioned a school system, created by each state according to their own interest, which would provide a basic education to inform the electorate. The modern school is expected to provide much more than that.

\footnotetext{
${ }^{216}$ U.S. Department of Health \& Human Services, Key Components in State Anti-Bullying Laws. Accessed on July 1, 2013. Retrieved from: www.stopbullying.gov.

${ }^{217}$ Sameer Hinduja and Justin W. Patchin. State Cyberbullying Laws and Policies. Accessed on July 1, 2013. Retrieved from: www.cyberbullying.us
} 
How then, exactly, are administrators to address this issue of off campus internet speech causing problems at school? There is a wealth of information and opinions that express that schools should address the issue of off-campus speech in the interest of student safety and protecting victims, without infringing on free speech rights, and while providing training and programming on the topic, with no additional funding, or else risk legal action or jeopardizing the learning environment of any and all students. It is a tricky situation indeed. What are the key considerations for administrators in addressing these incidents then?

\section{Philosophy of Education/ General Leadership}

Educational leaders must consider their own philosophy and leadership goals in determining how best to handle the off-campus internet speech issues they encounter. This becomes a complex endeavor as schools are counted on to provide more and varied services to students. Richard Elmore makes a case that schools are being asked to do something they have never been asked to do before and that is to educate all children. ${ }^{218}$ Schools have long been a sorting agency to determine who can move on to higher education and a better future and who may not make that move. The accountability movement and No Child Left Behind have challenged that role. The question of school authority and student rights really falls into the debate over what we expect from schools in that traditionally those students who did not follow the rules, in any number of ways, were often expelled and thus removed from the educational process and thus left behind. Truly wanting to leave no child behind will require philosophy and action from educational leaders that looks for new and inclusive methods for keeping students in

${ }^{218}$ Richard Elmore, School Reform From the Inside Out: Policy, Practice, and Performance. (Cambridge, MA: Harvard Education Press, 2006). 
school. School leaders must closely examine whether this is the genuine outcome they are searching for and then commit the personnel and resources needed to change schools to meet such an expectation. Richard Elmore points out that supporting accountability standards such as No Child Left Behind is not enough. In order to truly change the educational system for all children to succeed “...requires major investments in infrastructure at the state and local level to meet the requirements of expertise and support for failing schools. ${ }^{219}$ He points out that improvement is a process and not an event and people should realize that such a process is not going to be a quick and easy fix.

Diane Ravitch, former Assistant Secretary of Education, likewise promotes the idea that education needs reforming, but not simply at the schoolhouse. Ravitch argues that all stakeholders need to ante up as we need a strong and vibrant educational system once again. "As we seek to reform our schools, we must take care to do no harm...At the present time, public education is in peril. Efforts to reform public education are, ironically, diminishing its quality and endangering its very survival." ${ }^{220}$ School leaders cannot do it alone. They must create inclusive schools systems that count on local communities to help carry out this paradigm shift, in financial terms as well as in terms of community expectations.

An administrator must begin from the perspective of fulfilling what they see their role to be within the myriad of demands and requests put on them. Lee Bolman \& Terrence Deal in their book Reframing Organizations examine the various frameworks

${ }^{219}$ Richard Elmore, School Reform From the Inside Out: Policy, Practice, and Performance, 254. ${ }^{220}$ Diane Ravitch, The Death and Life of the Great American School System: How Testing and Choice are Undermining Education. (New York, NY: Basic Books, 2010) 241. 
through which administrators might view the school setting. While they spend the majority of the book describing each of the various frameworks, they point out, "But making sense of a complex situation is not a single-framed activity. A messy, turbulent world rarely presents bounded, well-defined problems." 221 No matter what that perspective is, administrators are charged with providing a quality education to all students. Any educator can reflect on their undergraduate psychology course and recall that the first two needs in Maslow's Heirarchy of Needs that must be met before any learning can take place are the biological/ physiological needs and safety. ${ }^{222}$ Internet speech can potentially challenge those needs. A student will have great difficulty in learning and concentrating in school if the fear of what may happen in the hallway or on the way home is in the back of their mind due to a comment or post made on the internet. Providing a safe and orderly environment free from fear and harassment is essential to the functioning of the school.

Building administrators must also consider the perspective of being the educational leader in their schools. As such, it is the administrator who must set the tone in terms establishing an environment conducive to learning. This may range from one end of the spectrum in the form of someone like Dr. Nell Noddings who wrote extensively on the need for caring in education, something she termed the ethic of care. She believed that the need for both given care and received care were essential

\footnotetext{
${ }^{221}$ Lee Bolman and Terrence Deal. Reframing Organizations. (San Francisco, CA: Jossey-Bass, 2008), p. 309.

${ }^{222}$ Saul McLeod. Maslow's Hierarchy of Needs. Simply Psychology. (June 2007.) p.11 Retrieved from http://www.simplypsychology.org/maslow.html on October 12, 2012.
} 
components of the human condition. ${ }^{223}$ Caring about the students' emotional, physical, and intellectual growth and well being could drive an administrator to be certain the issue is addressed in an appropriate manner. A perspective from the other end of the spectrum might be similar to any of the frameworks described by Bolman and Deal. Such a perspective would view students almost as a product to be created, which ultimately administrators would want the educational environment such that the product could be maximized. ${ }^{224}$ While no one administrator is going to fall solely within one perspective all of the time, it is clear that creating an environment where students feel safe and have the opportunity to learn free from fear and distractions is essential no matter their personal style or perspective. A leadership style such as servant leadership would lend itself well to addressing such an issue. James Autry writes in his book The Servant Leader that true leaders are authentic, vulnerable, accepting, present, and useful to the people they lead. ${ }^{225}$ These characteristics seem to be a prerequisite for dealing with such a complex and challenging situation. Autry points out that the characteristics of the servant leader have, "even more meaning and impact during the times when people are worried and struggling." 226 This issue certainly produces struggle and worries for those involved. Providing an environment where all students can learn, specifically those who feel weak and powerless, is a must.

The current age is not going to wait for society to debate and articulate where it envisions this struggle moving. School leaders have been asked to deal with the fallout

\footnotetext{
${ }^{223}$ Nell Noddings. "What does it mean to educate the whole child?" Educational Leadership, 2005. 63(1), p. 8-13.

${ }^{224}$ Lee Bolman and Terrence Deal. Reframing Organizations. (San Francisco, CA: Jossey-Bass, 2008).

${ }^{225}$ James Autry. The Servant Leader. (New York, NY: Three Rivers, 2004).

${ }^{226} \mathrm{Ibid}$, p. 224.
} 
from off-campus speech due to the internet. In most of these instances, there is interaction at school on some level between the two parties involved in the off-campus statements. The instantaneous access to information provided by the internet has blurred the lines of schoolyard and backyard. The Supreme Court has turned down the opportunity to clarify the issue as recently as 2012 . "The unintended consequences of the Information Age, however, have caused a dysbiosis of knowledge and information and, thereby, inverted the roles of the significant actors in the pedagogical enterprise. This issue is not easily resolved because even when new policies and/ or new training practices are executed they are likely to have a short shelf life. Collectively, it is clear that the impact of technology on student expression rights, or administrative authority to control expression, has not yet resulted in a set of definitive or prevailing legal patterns." ${ }^{227}$ As the Supreme Court declined the opportunity to examine a series of cases on the topic in January 2012, school administrators will be left to navigate very gray waters in dealing with the related issues. A leadership philosophy that looks to educate and include as many students as possible and still protect the rights of all those students will be of the utmost importance until the courts provided some guidance on the issue.

Francisco M. Negron, as lead counsel in authoring an Amici Curiae brief on behalf of the National School Boards Association; American Association of School Administrators; American School Counselor Association; The Gay, Lesbian, and Straight Education Association; and a half dozen other school personnel-related organizations and associations, wrote in the hope that the Supreme Court would take up a series of related

\footnotetext{
${ }^{227}$ PhilipT.K. Daniel, and Silas McCormick, "Technological Advances, Student Expression, and the Authority of School Officials", West's Education Law Reporter, 248 Ed. Law Rep. 553, November 12, 2009, p. 2.
} 
cases presented together on the topic. This list of groups and organizations having an interest in the case should bear consideration from school leaders in deciding how they deal with off-campus internet speech that makes its way on campus. Negron argued that the Supreme Court's guidance "...is critical to assisting school officials in understanding how they may regulate the student expression that now pervades social networking forums without contravening the time-honored principles of the First Amendment." ${ }^{228}$ Negron lays out the areas of confusion succinctly and practicing administrators would be wise to understand these issues when dealing with such cases. The first area of confusion is that even when the Tinker V. DesMoines Independent Community School District case is used as the default standard in judging off-campus speech, there is no clear definition of "substantial disruption" and school districts and their attorneys forecast such events in widely different manners. ${ }^{229}$ Second, while courts seem content in applying the Tinker standard to off-campus speech, there appears to be confusion among the courts as to whether or not the Bethel School District v. Fraser standard for lewd and indecent speech can likewise be applied to off-campus internet speech. ${ }^{230}$ Finally, the lower courts have left no clear standard as to whether and when to characterize online speech beginning off campus as on-campus speech. ${ }^{231}$ An understanding of such decisions and cases is essential to the building level administrator. The characteristics and makeup of each community and school, combined with an understanding of these lower court findings may determine the manner with which such cases are dealt.

\footnotetext{
${ }^{228}$ Francisco Negron, Amici Curiae Brief In The Supreme Court of the United States. No. 11-502, November 2, 2011, p. 3.

${ }^{229}$ Ibid, p.6.

${ }^{230}$ Ibid, p.7.

${ }^{231}$ Ibid, p.9.
} 
In short, school leaders must address the issue of bullying and harassment, whether originating on campus or not, so that all students may receive the education that schools are there to provide. It appears that schools will continue to be called to step-in and address potential bullying and harassment issues, but the fact that more than twenty cases have reached the Federal Courts dealing with discipline of off-campus internet speech shows that administrators had best tread lightly and have an understanding of the current court decisions so they may carry out their responsibilities.

\section{Finance}

The issue of finances must also be considered when addressing the issue of offcampus internet speech. The impact of cyber-bullying is well documented and dramatic. The psychological impact on young victims may lead to the inability of such students to cope with the school environment. With the rising cost of special education and alternative education programs, administrators must consider healthier alternatives. The percentage of students nationwide who were enrolled in special education programs climbed from $7.5 \%$ in 1976 to $12.2 \%$ in $2003 .{ }^{232}$ While not all of the growth could be attributed to students having trouble coping due to being bullied, the rising numbers certainly give reason to reflect on how many students are being moved in that direction. Additionally, the cost of special education is rising nationwide and two of the contributing factors are identified as funneling behavior problem students and learning problem students to special education as well as increased advocacy on the part of parents. Likewise, the increased number of students experiencing social stress

\footnotetext{
${ }^{232}$ Thomas B. Parrish. "National and State Overview of Special Education Funding." Center for Special Education Finance. Presentation given March 1, 2006.
} 
contributes to the special education cost increases. ${ }^{233}$ In the current era of reduced funding and increased expectations of performance, administrators must examine the impact of off-campus internet speech on select student populations such as those who are unable to cope due to the stress inflicted by such speech.

School leaders should also consider the impact on the student beyond the age of schooling. In those cases where students decide that they can no longer continue schooling because of the situation and opt instead to dropout, there is a negative impact for the life of the student. The U.S. Department of Commerce Census Bureau's Current Population Survey of 2009 found staggering financial implications for dropping out of high school. The median income for a person aged 18-67 who dropped out of high school was $\$ 25,000$ as opposed to $\$ 43,000$ for someone with a high school diploma or GED from the same age group. This amounts to approximately $\$ 630,000$ over the career of a person. ${ }^{234}$ Educational leaders whose leadership philosophy is to include as many students in the educational process as possible must find new avenues for helping these students stay in school. No student should have to be fearful of attending school due to the behaviors of fellow students.

These financial considerations also cross-over into the area of legal and policy considerations. The federal courts have witnessed more than 20 off-campus internet speech related cases come before them. Each of these cases began as a lawsuit filed against a school, teacher, administrator, support staff, fellow student or all of the above.

\footnotetext{
${ }^{233}$ Sheldon Berman and David Urion. "The misdiagnosis of special education costs." School Administrator. (March 2003). p. 6-10.

${ }^{234}$ U.S. Department of Commerce, Census Bureau. Current Population Survey. (October 2009). p. 1.
} 
The rising amount of litigation that school districts face must also be considered by educational leaders.

\section{Policy/ Legal}

In addition to the wave of reform rhetoric aimed at schools, the last fifteen years have also born witness to a number of horrific tragedies seemingly beginning with 1999's Columbine school shooting, through which the American public has become acutely aware of the potential for violence on public school campuses by school children. ${ }^{235}$ States have enacted legislation to address such perceived threats, including those that arise from off-campus technology. It would seem the public schools are not safe for our children if the headlines were the whole story. With all of this criticism and these issues in mind, David Berliner and Bruce Biddle in their book The Manufactured Crisis offer, "it is, in fact, amazing that American educators cope as well as they do, that in the face of the myriad barriers they manage to educate so many students, to such a high standard."236

The issue of off-campus internet speech by students is not solely about cyberbullying, however. Some of the other issues that have arisen include students making threatening or derogatory commentary toward or about teachers such as in the case of Joanne Killion v. Franklin Regional School District. The case resulted when the mother of Zachariah Paul filed suit because her son was disciplined for off campus speech that was brought to school by another student. ${ }^{237}$ In short, the student was

\footnotetext{
${ }^{235}$ Diane Heckman, "Just Kidding: K-12 Students, Threats, and First Amendment Freedom of Speech Protection", West's Education Law Reporter, 259 Ed. Law Rep. 381, October 28. $2010,1$. ${ }^{236}$ David Berliner and Bruce Biddle, The Manufactured Crisis (Reading, MA: Addison-Wesley Publishing Company, 1995), 12 .

${ }^{237}$ Killion v. Franklin Regional School District, 136 F.Supp.2d 446, (W.D. Penn. 2001).
} 
disciplined when he authored a derogatory Top Ten list about the athletic director and a friend brought a copy to school.

Lawsuits have been filed on both sides of the issue and the courts have produced a very nearly equal split of decisions in favor of each side. The Supreme Court has intentionally stayed out of the fray and left schools and lower courts to sift through the issue at this point, resulting in mixed outcomes and sometimes contradictory findings on very similar cases.

One might ask, should schools be bothering with these issues if the authority to do so is so unclear? The United States Department of Education through the Office for Civil Rights felt the issues of bullying and harassment were still a prevalent enough problem to issue a "Dear Colleague" letter reminding state departments of education and school districts that harassment and bullying can fall under antidiscrimination laws and potentially rise to the level of civil rights violations. ${ }^{238}$ A fact sheet accompanying the letter also listed the effects of bullying and harassment, including lowered academic achievement and aspirations, increased anxiety, loss of self-esteem and confidence, depression and post-traumatic stress, general deterioration in physical health, self-harm and suicidal thinking, feelings of alienation in the school environment, fear of other children, and absenteeism from school. ${ }^{239}$

Likewise, an Executive Summary issued by the Illinois School Bullying Prevention Task Force identified the consequences of bullying and harassment, whether to perpetrator or victim, as including feeling unsafe resulting in skipping school,

${ }^{238}$ United States Department of Education Office for Civil Rights. "Dear Colleague Letter: Harassment and Bullying." (October 26, 2010.) p.1-10.

${ }^{239}$ United States Department of Education Office for Civil Rights. "Dear Colleague Letter: Harassment and Bullying. Background, Summary, and Fact Sheet" (October 26, 2010.) p. 1-2. 
decreased college ambitions, increased incidents of violence, increased incidence of carrying weapons to school, increased drug use, increased depression, increased suicide attempts, and increased criminal activity. ${ }^{240}$

While it would seem logical that over time this issue would move into clearer focus, the truth is quite to the contrary. The Supreme Court in fact declined to hear cases on student internet speech in January of 2012. ${ }^{241}$ Court cases leading up to today have certainly addressed issues as they have arisen, such as students wearing symbolic armbands in protest of societal issues. Can students make statements or take actions that significantly disrupt the educational environment in the name of free speech? Current media portrayals would lead people to believe the foundation of public education is in a shaky position. Social networking and technology such as cell phones have so radically changed the nature of communication, traditional definitions of school responsibilities and boundaries no longer accurately fit.

No matter the approach considered, there are some basic policy cornerstones that must be in place. In an article titled "MySpace, SchoolSpace: Is Your Computer Safe" in the Illinois School Board Journal, attorney Laura Hemmer offers that school policy must balance student internet safety and the Constitutional protections of the First Amendment. She argues that "...every District's approach to internet safety should begin with a solid and effective Acceptable Use Policy (AUP) governing student access to and use of school

\footnotetext{
${ }^{240}$ Illinois School Bullying Prevention Task Force. "Executive Summary." (March 1, 2011.) p. 1.

${ }^{241}$ Mark Walsh, "Supreme Court Declines Cases on Student Internet Speech", Education Week Blog, January 17. 2012. Retrieved from: http://blogs.edweek.org/edweek/school law/2012/01/supreme court declines cases o.html Accessed on January 18, 2012.
} 
networks and e-mail." ${ }^{242}$ This suggestion obviously falls short of solving the current dilemma and Hemmer continues that many districts go beyond this minimum and specifically ban the use of social networking sites, and other social media as well as describing potential penalties for violating such bans. It is a necessity to create policy that will both guide student behavior and administrative action while being flexible enough to deal with technologically related issues as they arise.

While most of the current literature urges school leaders to examine school policy and rewrite it to meet the challenges of the situation, very little specific guidance is given on how to accomplish such changes. Lawyer Nancy Willard, writing for the Center for Safe and Responsible Use of the Internet, argued that most current policy is in line with the current legal situation and schools really did not have the authority to deal with offcampus issues. What schools needed to do according to Willard was monitor the impact of cyberbullying on the school setting and respond accordingly. If a student feels unsafe or cannot concentrate due to cyberbullying, then the act has substantially disrupted the operation of the school and action can and should be taken. ${ }^{243}$ But the courts are not nearly as certain as Ms. Willard is. Tara Sydney suggests that in addition to an acceptable use policy, schools should attempt a comprehensive anti-cyberbullying campaign that includes students, teachers, administrators, parents, and community members to raise awareness and options available to students who experience or witness

\footnotetext{
${ }^{242}$ Laura Hemmer. "'MySpace, SchoolSpace: Is Your Computer Safe" Illinois School Board Journal. Retrieved from http://www.iasb.com/journal/j091008 08.cfm on January26, 2012. ${ }^{243}$ Nancy Willard. "Cyberbullying Legislation and School Policies: Where Are the Boundaries of the Schoolhouse Gate in the New Virtual World?" Center for Safe and Responsible Use of the Internet. (March 2007). P.6-8.
} 
cyber-bullying and online issues. ${ }^{244}$ She writes that such a campaign could include teachers promoting cyber ethics, teachers assigning news articles and journal activities on the topic, students reading and writing about it, showing movies or documentaries about the issue, bringing in community members to speak on the impact, and even creating a school wide cyber ethics guidelines program to display and promote. ${ }^{245}$

While there is much discussion about the need for policy, the current legal landscape limits the changes in policy a school district might be able to institute. The one area that does have some flexibility for administrators is to cover cyber behavior in the student code of conduct policies that many schools use to govern behavior of those in extracurricular activity. As shown in the case of Vernonia v. Acton, the courts give the schools more flexibility in dealing with student behavior when the penalty revolves around extracurricular participation.

State law must also be considered to ensure compliance when dealing with offcampus internet speech that makes its way on campus, even if the Supreme Court has not addressed the issue specifically. In Illinois, these include portions of the school code such as 720 ILCS 120/5 from 1996 which describes that an act of hazing has occurred when a person knowingly requires the performance of an act by a student or other person in a school, college, university or other educational institution, for purpose of induction or admission into any group, organization or society associated with or connected with

\footnotetext{
${ }^{244}$ Tara Sydney. "Cyberbullying: Challenges and Actions." Journal of Family and Consumer Sciences. (Fall 2009). P. 40-46.

${ }^{245}$ Ibid, p. 46.
} 
that institution, if the act is not sanctioned or authorized by the institution and the act results in bodily harm. ${ }^{246}$

Likewise, section 105 ILCS 5/10-20.14:14 changed in 2002 and requires the school board, with the parent-teacher advisory committee and community based organizations, to include provisions in the student discipline policy to address students who have demonstrated signs that put them at risk for aggressive behavior, including without limitation, bullying. ${ }^{247}$

Section 105 ILCS 135/1-2 from 2008 defines harassment through electronic communications. The definition includes "...making any obscene comment, request, suggestion or proposal with an intent to offend...," and "...threatening injury to the person or to the property of the person to whom the electronic communication is directed or to any of his family or household members." Violation of the provisions of the statute will result in a class B misdemeanor. ${ }^{248}$

Finally, section 105 ILCS 5/27-23.7, which changed in 2010, prohibits bullying (as defined in the statute) in the school environment and includes language addressing electronic communications. Bullying is specifically prohibited through the transmission of information from a school computer, a school computer network, or other similar electronic school equipment.

Reading through the sections of the school code shows the steps the state has made to address the issue of hazing, harassment, and aggressive behavior over the years.

\footnotetext{
${ }^{246}$ Olweus Bullying Prevention Program. Retrieved from http://www.olweus.org/public/laws_illinois.page (accessed February 5, 2011). ${ }^{247}$ Ibid.

${ }^{248}$ Ibid.
} 
School leaders must make sure to abide by these guidelines in enforcing policy and in any new policy or application of policy to be considered. These regulations deal exclusively with on campus behavior however.

\section{Community Relations}

Modern school leaders must also consider the community that they serve when dealing with student internet speech. Unlike days gone by when schools operated under the concept of in loco parentis, schools must now balance the rights of a student to make comments online away from school with the rights of the student who is impacted by that speech and may feel some effect of the speech while at school. According to the U.S. National Center for Education Statistics and U.S. Department of Justice, 32.7\% of students nationwide reported being bullied at school in some form with an additional $4 \%$ indicating being cyber bullied in addition to the school bullying. ${ }^{249}$ The nightly news shows us the worst of the worst cyberbullying and bullying cases such as the tragedy of Phoebe Prince. Prince was an Irish girl who moved to South Hadley, Massachusetts and started dating a popular football player. Some girls in town became jealous and began to harass her on Facebook and at school. By January she had enough and after one particularly bad day she committed suicide in her home after school. The parents sued the school and criminal charges were filed against the girls, who mocked her death on the internet. ${ }^{250}$ The incident was a tragedy for the girl and her family and became a media nightmare for the school. Nightly news broadcasts in the days and weeks after the event

\footnotetext{
${ }^{249}$ U.S. National Center for Education Statistics and U.S. Department of Justice, Bureau of Justice Statistics, Indicators of School Crime and Safety:2009. December, 2009, NCES2010, p. 112.

${ }^{250}$ Nancy Gibbs. "When Bullying Goes Criminal." Time-Online Edition. (April 19, 2010.) p. 13.
} 
depicted a school that was aware of the situation and did not take action. The school offered very little counter argument to the media, oftentimes citing issues of privacy. School leaders would be wise to provide awareness and training to staff and students regarding internet speech and safety, and to publicize the actions they are taking as well. Communicating with the families that schools serve is a key aspect of the job for educational leaders.

\section{Curriculum \& Instruction}

School leaders would also do well to explore the issue of off-campus internet speech as policy and teacher training are a key suggestion repeated throughout the literature on the topic. The Department of Education's "Dear Colleague" letter of October 2010 stated that when investigating incidents of harassment, "...depending on the extent of the harassment, the school may need to provide training or other interventions not only for the perpetrators, but also for the larger school community, to ensure that all students, their families, and school staff can recognize harassment if it recurs and know how to respond." 251

The Illinois School Bullying Prevention Task Force in 2010 also made recommendations for schools to address the issue of bullying and harassment including replacing zero-tolerance policies and punitive discipline practices with restorative discipline policies and practices, providing effective youth programs to educate students on the issues, and providing professional development to all school personnel on both impacts and expectations. ${ }^{252}$ It is interesting to note the shift away from the zero

${ }^{251}$ United States Department of Education Office for Civil Rights. "Dear Colleague Letter: Harassment and Bullying." (October 26, 2010.) p. 3.

${ }^{252}$ Illinois School Bullying Prevention Task Force. "Executive Summary.” (March 1, 2011.) p. 2. 129 
tolerance policies that spread like wildfire after the school shooting at Columbine. Michel Foucalt wrote of the effects of punishment on prisoners as penal codes changed from physical punishment to incarceration and reform in his work Discipline \& Punish. ${ }^{253}$ While he was writing of a prison system undergoing change centuries ago, he noted that the criminal changed, but crime was not erased. Similarly, Richard Skirba argues that no evidence exists to support the harsh penalties imposed under zerotolerance actually deter behavior. ${ }^{254}$ It appears as though the State of Illinois believes likewise that administrators should stay in line with state initiatives. It is important that administrators know where to turn for alternatives if their school or district is a zero tolerance school and looking for alternatives, such as a positive behavior system, to replace the current zero tolerance policy. ${ }^{255}$ These types of policies would look to provide education and opportunities for correction and growth rather than a "one strike and you are out" mentality enforced by zero-tolerance policies.

The Department of Education and Illinois School Bullying Prevention Task Forces have the best of intentions in making suggestions and reminders as to what schools should do to address the issue, such as programming and opportunities for change and growth. They seldom provide the funding or specific action steps to be taken in achieving the changes however. It is important for administrators to remember that their own district or school provides a unique set of strengths and weaknesses in enacting such changes. As Newman, Kings, and Youngs point out in their article Professional

\footnotetext{
${ }^{253}$ Michel Foucault. (A. Sheridan trans.). Discipline \& Punish: The birth of the prison. (NewYork, N.Y.: Vintage, 1975).

${ }^{254}$ Richard Skirba, R. Zero Tolerance: Zero Evidence. (Bloomington, IN: Indiana Education Policy Center, 2000.)

${ }^{255}$ Positive Behavior Incentive System. Retrieved from http://www.pbis.org on October 8, 2012.
} 
Development That Addresses School Capacity: Lessons From Urban Elementary

Schools, "Each school contains a unique mix of many teachers' and students'

competencies and attitudes and a unique set of social, cultural, and political conditions,"

all of which must be considered in deciding how best to implement any sort of staff and student training or program. ${ }^{256}$ These strengths may lead to decisions about the people involved, time programs are offered, nature of those programs, and time of implementation. There may not be a single wrong or right method in implementing such training but rather the wrong or right method for a given situation.

\section{Conclusions/ Predictions}

The issue of student internet speech is a modern catch 22 for school administrators. On one side of the issue are parents demanding that something be done to protect their student from the negative impacts of cyberbullying, such as the horrific headlines in cases such as Phoebe Prince. These parents also demand punishment for perceived bullies. On the other side of the argument are those parents who claim that student speech made off campus, not accessed at school, and not related to school is none of the school's business. There is a thing called the first amendment and it does protect the people of the United States from having their right to free speech taken away. The media shocks us nightly with images and stories of students harming themselves or others as a result of bullying. The cost for programming to educate on the topic rises daily with little or no extra funds from the state and federal governments. The cost to educate students who cannot cope due to the impact of such speech also grows daily as more and

\footnotetext{
${ }^{256}$ Fred M. Newmann, M. Bruce King, and Peter Youngs. "Professional development that addresses school capacity: Lessons from urban elementary schools." American Journal of Education, (August, 2010)p. 260.
} 
more students are unable to cope with such issues. How is an administrator to address all of these demands? The answer is that the administrator must strive to create the best possible learning environment for all students. The financial cost, the legal liability issues, the need for programming and education on the topic, diminishing resources, and increased expectations must all be considered in deciding how best to serve students in providing a quality education within that context. That ultimately is what administrators are charged with. A solid understanding of Supreme Court jurisprudence on student first amendment issues, along with staying abreast of current court cases and rationale, will aid greatly in that endeavor. Until the Supreme Court decides to take up such a case to clarify the issues surrounding internet student speech, administrators must examine each case on its own set of facts and decide if it best serves students to pursue the issue and whether there is legal support to do so. The task is not easy, but it is the reality for administrators in the modern technological era. 


\section{REFERENCES}

Autry, James. The Servant Leader. New York, NY: Three Rivers, 2004.

Berliner, David and Bruce Biddle. The Manufactured Crisis. Reading, MA: AddisonWesley Publishing Company, 1995.

Berman, Sheldon and David Urion. "The misdiagnosis of special education costs." School Administrator. March 2003. p. 6-10.

Blackstone, Sir William. Commentaries on the Laws of England of vol. 1, ed. Robert Malcolm Kerr. London, England: William Clowes and Sons, 1876.

Bolman, Lee and Terrence Deal. Reframing Organizations. San Francisco, CA: JosseyBass, 2008.

Daniel, Philip T.K.and Silas McCormick, "Technological Advances, Student Expression, and the Authority of School Officials", West's Education Law Reporter, 248 Ed. Law Rep. 553, November 12, 2009.

Elmore, Richard. School Reform From the Inside Out: Policy, Practice, and Performance. Cambridge, MA: Harvard Education Press, 2006.

Foucault, Michel(A. Sheridan trans.). Discipline \& Punish: The birth of the prison. (NewYork, N.Y.: Vintage, 1975).

Gibbs, Nancy. "When Bullying Goes Criminal." Time. April 19, 2010.

Heckman, Diane. "Just Kidding: K-12 Students, Threats, and First Amendment Freedom of Speech Protection", West's Education Law Reporter, 259 Ed. Law Rep. 381, October 28, 2010.

Hemmer, Laura. "'MySpace, SchoolSpace: Is Your Computer Safe" Illinois School Board Journal. Retrieved from http://www.iasb.com/journal/j091008 08.cfm on January26, 2012.

Illinois School Bullying Prevention Task Force. "Executive Summary.” March 1, 2011.

Lucas, Christopher. Our Western Educational Heritage. New York: Macmillan Company, 1972. 
McLeod, Saul Maslow's Hierarchy of Needs. Simply Psychology. (June 2007.) Retrieved from http://www.simplypsychology.org/maslow.html on October 12, 2012.

Negron, Francisco. Amici Curiae Brief In The Supreme Court of the United States. No. 11-502, November 2, 2011.

Newmann, Fred M., M. Bruce King, and Peter Youngs. "Professional Development That Addresses School Capacity: Lessons From Urban Elementary Schools." American Journal of Education. August, 2010.

Noddings, Nell. "What does it mean to educate the whole child?" Educational Leadership, 2005. 63(1), p. 8-13.

Olson, Lynn and Alan Richard. "High Schools in Limelight for Summit" Education Week, February 23, 2005, 24(24), 20.

Olweus Bullying Prevention Program. Retrieved from http://www.olweus.org/public/laws_illinois.page (accessed February 5, 2011).

Parrish, Thomas B. "National and State Overview of Special Education Funding." Center for Special Education Finance. Presentation given March 1, 2006.

Positive Behavior Incentive System. Retrieved from http://www.pbis.org on October 8, 2012.

Ravitch, Diane. The Death and Life of the Great American School System: How Testing and Choice are Undermining Education. New York, NY: Basic Books, 2010.

Safford Unified School District \#1 v. April Redding, 129 S.Ct. 2633, (2009).

Skirba, Richard. Zero Tolerance: Zero Evidence. Bloomington, IN: Indiana Education Policy Center, 2000.

Sydney, Tara. "Cyberbullying: Challenges and Actions." Journal of Family and Consumer Sciences. (Fall 2009). P. 40-46.

U.S. Department of Commerce, Census Bureau. Current Population Survey. October 2009.

U. S. Department of Education Office for Civil Rights. "Dear Colleague Letter: Harassment and Bullying." October 26, 2010.

U.S. National Center for Education Statistics and U.S. Department of Justice, Bureau of Justice Statistics, Indicators of School Crime and Safety: 2009. December, 2009. 
Walsh, Mark. "Supreme Court Declines Cases on Student Internet Speech", Education Week Blog, January 17. 2012. Retrieved from:

http://blogs.edweek.org/edweek/school law/2012/01/supreme court declines cas es_o.htmlml Accessed on January 18, 2012.

Willard, Nancy. "Cyberbullying Legislation and School Policies: Where Are the Boundaries of the Schoolhouse Gate in the New Virtual World?" Center for Safe and Responsible Use of the Internet. March, 2007. 


\section{APPENDIX A}

FEDERAL LEVEL CASE MATRIX

\begin{tabular}{|c|c|c|c|c|}
\hline$C A S E$ & FACTS/ OUTCOME & $\begin{array}{c}\text { STANDARD } \\
\text { APPLIED/ } \\
\text { FINDINGS }\end{array}$ & RATIONALE & IMPLICATIONS \\
\hline $\begin{array}{l}\text { Beussink v. } \\
\text { Woodland R- } \\
\text { IV School } \\
\text { District, } 30 \mathrm{~F} \text {. } \\
\text { Supp. 2nd } \\
1175 \text { (1998). }\end{array}$ & $\begin{array}{l}\text { Student created a webpage } \\
\text { criticizing school \& admin. } \\
\text { Student suspended when } \\
\text { principal found out about } \\
\text { webpage through third party. } \\
\text { Student suspended } 10 \text { days. }\end{array}$ & $\begin{array}{c}\text { Ruling: } \\
\text { Student } \\
\text { Standard: } \\
\text { Tinker }\end{array}$ & $\begin{array}{l}\text { There was no } \\
\text { substantial disruption } \\
\text { to the school } \\
\text { day the language was } \\
\text { merely unfavorable to } \\
\text { the administration. }\end{array}$ & $\begin{array}{l}\text { Schools need to be able } \\
\text { to prove a substantial } \\
\text { disruption or the } \\
\text { likelihood of such a } \\
\text { disruption in order to } \\
\text { discipline. }\end{array}$ \\
\hline $\begin{array}{c}\text { Emmett v. } \\
\text { Kent School } \\
\text { District, } 92 \mathrm{~F} \text {. } \\
\text { Supp. 2d } \\
1088(2000) .\end{array}$ & $\begin{array}{l}\text { Student created an unofficial } \\
\text { webpage for his high school } \\
\text { that included "mock" } \\
\text { obituaries and allowed } \\
\text { visitors to vote on whose } \\
\text { would be next. Student } \\
\text { suspended } 5 \text { days. }\end{array}$ & $\begin{array}{l}\text { Ruling: } \\
\text { Student } \\
\text { Standard: } \\
\text { None }\end{array}$ & $\begin{array}{l}\text { The speech was } \\
\text { entirely off campus } \\
\text { and was clearly not } \\
\text { intended to be a true } \\
\text { threat but rather was } \\
\text { intended as a mock } \\
\text { site. }\end{array}$ & $\begin{array}{l}\text { Schools should be } \\
\text { certain that the speech/ } \\
\text { behavior has impacted } \\
\text { the school if it has not } \\
\text { actually occurred there. } \\
\text { If it is entirely off } \\
\text { campus a school may not } \\
\text { be able to act. }\end{array}$ \\
\hline $\begin{array}{l}\text { Killion v. } \\
\text { Franklin } \\
\text { Regional } \\
\text { School } \\
\text { District, } 136 \\
\text { F. Supp. 2d } \\
\text { 446 (2001). }\end{array}$ & $\begin{array}{l}\text { Student created a top ten list } \\
\text { containing derogatory } \\
\text { comments about the AD and } \\
\text { sends it to friends. A third } \\
\text { party brought it to school, } \\
\text { resulting in the creator being } \\
\text { suspended } 10 \text { days. }\end{array}$ & $\begin{array}{l}\text { Ruling: } \\
\text { Student } \\
\text { Standard: } \\
\text { Tinker } \\
\text { (mentions } \\
\text { Fraser) }\end{array}$ & $\begin{array}{c}\text { Found in favor of } \\
\text { student because the } \\
\text { school failed to meet } \\
\text { the substantial } \\
\text { disruption aspect of } \\
\text { Tinker. Mentions the } \\
\text { lewd and derogatory } \\
\text { language of Fraser } \\
\text { but found it does not } \\
\text { apply as the language } \\
\text { occurred at home. }\end{array}$ & $\begin{array}{l}\text { Tinker was applied even } \\
\text { though the creator did } \\
\text { not bring the list to } \\
\text { school. The key element } \\
\text { in this decision again } \\
\text { was the failure of the } \\
\text { school to demonstrate a } \\
\text { substantial disruption not } \\
\text { if it occurred off school } \\
\text { grounds. }\end{array}$ \\
\hline $\begin{array}{l}\text { Coy v. Board } \\
\text { of Education } \\
\text { of the North } \\
\text { Canton City } \\
\text { Schools, 205 } \\
\text { F. Supp. 2d } \\
791(2002) .\end{array}$ & $\begin{array}{l}\text { Student created a website } \\
\text { criticizing fellow students and } \\
\text { describing them as losers. He } \\
\text { then accessed the website at } \\
\text { school. Student was } \\
\text { suspended for } 4 \text { days and put } \\
\text { on probation for } 80 .\end{array}$ & $\begin{array}{l}\text { Ruling: } \\
\text { Student } \\
\text { Standard: } \\
\text { Tinker }\end{array}$ & $\begin{array}{l}\text { Again applied the } \\
\text { substantial disruption } \\
\text { test of Tinker and } \\
\text { found the school had } \\
\text { not demonstrated } \\
\text { such a disruption. } \\
\text { Court also discussed } \\
\text { that one particular } \\
\text { school policy that } \\
\text { allowed the school to } \\
\text { punish for undefined } \\
\text { inappropriate action } \\
\text { was overly vague and } \\
\text { unconstitutional. }\end{array}$ & $\begin{array}{c}\text { Schools must be able to } \\
\text { document a substantial } \\
\text { disruption or likelihood } \\
\text { of such a disruption. In } \\
\text { creating policy schools } \\
\text { should also take notice } \\
\text { of the unconstitutional } \\
\text { finding for catch-all } \\
\text { policies. }\end{array}$ \\
\hline
\end{tabular}




\begin{tabular}{|c|c|c|c|c|}
\hline $\begin{array}{l}\text { Mahaffey v. } \\
\text { Aldrich, } 236 \\
\text { F. Supp. 2d } \\
779 \text { (2002). }\end{array}$ & $\begin{array}{l}\text { Student created a website in a } \\
\text { joking manner that listed } \\
\text { fellow students that he wished } \\
\text { would die. Student } \\
\text { suspended but not expelled } \\
\text { for most of the semester. }\end{array}$ & $\begin{array}{c}\text { Ruling: } \\
\text { Student } \\
\text { Standard: } \\
\text { None }\end{array}$ & $\begin{array}{l}\text { Court declared that } \\
\text { Tinker does not apply } \\
\text { as the speech was off } \\
\text { campus. The speech } \\
\text { was also not a true } \\
\text { threat as no } \\
\text { reasonable person } \\
\text { would think the } \\
\text { author actually } \\
\text { wanted to kill the } \\
\text { people listed. }\end{array}$ & $\begin{array}{l}\text { Schools must be certain } \\
\text { that it is in fact a school } \\
\text { issue before doling out } \\
\text { discipline. Offensive } \\
\text { statements made at home } \\
\text { are not enough. If the } \\
\text { speech is thought to be } \\
\text { an actual threat school } \\
\text { actions should reflect } \\
\text { that and include law } \\
\text { enforcement. }\end{array}$ \\
\hline $\begin{array}{l}\text { J.S. v. } \\
\text { Bethlehem } \\
\text { Area School } \\
\text { District, } 807 \\
\text { A. } 2 \text { d } 847 \\
(2002)\end{array}$ & $\begin{array}{l}\text { Student created a website that } \\
\text { targeted the principal and a } \\
\text { teacher. The teacher took a } \\
\text { leave of absence due to the } \\
\text { stress. Student suspended } 10 \\
\text { days then expelled. }\end{array}$ & $\begin{array}{l}\text { Ruling: } \\
\text { School } \\
\text { Standard: } \\
\text { Tinker }\end{array}$ & $\begin{array}{l}\text { Court declared that } \\
\text { even though the } \\
\text { speech occurred off- } \\
\text { campus, it was aimed } \\
\text { exclusively at the } \\
\text { school and } \\
\text { completely disrupted } \\
\text { the school } \\
\text { environment. Court } \\
\text { also made mention } \\
\text { that such a disruption } \\
\text { need not actually } \\
\text { occur, but school only } \\
\text { need reason to believe } \\
\text { that such a disruption } \\
\text { was likely to occur. }\end{array}$ & $\begin{array}{l}\text { Schools that demonstrate } \\
\text { a substantial disruption } \\
\text { have a far better chance } \\
\text { of prevailing on } \\
\text { judgment. }\end{array}$ \\
\hline $\begin{array}{l}\text { Flaherty v. } \\
\text { Keystone } \\
\text { Oaks School } \\
\text { District, 247 } \\
\text { F. Supp. 2d } \\
698(2003) .\end{array}$ & $\begin{array}{l}\text { Student posted negative } \\
\text { internet messages about the } \\
\text { boy's volleyball team. He } \\
\text { was punished according to the } \\
\text { student handbook. }\end{array}$ & $\begin{array}{c}\text { Ruling: } \\
\text { Student } \\
\text { Standard: } \\
\text { Tinker }\end{array}$ & $\begin{array}{l}\text { This case did not } \\
\text { touch on the issue of } \\
\text { off-campus speech } \\
\text { but rather applied the } \\
\text { substantial disruption } \\
\text { element of Tinker. } \\
\text { The court found the } \\
\text { schools simply did } \\
\text { not demonstrate a } \\
\text { substantial disruption. } \\
\text { Court also mentioned } \\
\text { overbroad and vague } \\
\text { policies in this case. }\end{array}$ & $\begin{array}{l}\text { Schools must } \\
\text { demonstrate the } \\
\text { substantial disruption } \\
\text { criteria has been met to } \\
\text { punish. Court in this } \\
\text { case also mentioned that } \\
\text { policies are overbroad if } \\
\text { they are not connected to } \\
\text { actions that meet this } \\
\text { Tinker standard. Court } \\
\text { also stated a policy is } \\
\text { vague if it does not give } \\
\text { students adequate } \\
\text { warning of the behavior } \\
\text { that could be punished. } \\
\text { Again, the catch-all } \\
\text { policies are questionable. }\end{array}$ \\
\hline $\begin{array}{c}\text { Neal v. Efurd, } \\
\text { No.04-2195 } \\
\text { (2005). }\end{array}$ & $\begin{array}{c}\text { Two students created } \\
\text { websites critical of their } \\
\text { school. One was more severe } \\
\text { than the other. Neither was } \\
\text { accessed at school. Both } \\
\text { suspended } 3 \text { days when sites } \\
\text { were brought to the } \\
\text { principal's attention by } \\
\text { concerned students and } \\
\text { teachers. }\end{array}$ & $\begin{array}{c}\text { Ruling: } \\
\text { Student } \\
\text { Standard: } \\
\text { Tinker }\end{array}$ & $\begin{array}{l}\text { Court found that there } \\
\text { was no substantial } \\
\text { disruption to the } \\
\text { school. In fact, } \\
\text { unfounded } \\
\text { apprehensions by } \\
\text { some people involved } \\
\text { did not create a } \\
\text { reasonable likelihood } \\
\text { of substantial } \\
\text { disruption. }\end{array}$ & $\begin{array}{l}\text { Schools should tread } \\
\text { lightly when dealing } \\
\text { with complaints brought } \\
\text { to them by concerned } \\
\text { parents, students, and } \\
\text { staff. This provides an } \\
\text { interesting contrast to } \\
\text { bullying and harassment } \\
\text { issues that circulate in } \\
\text { the media currently. }\end{array}$ \\
\hline
\end{tabular}




\begin{tabular}{|c|c|c|c|c|}
\hline $\begin{array}{l}\text { Latour v. } \\
\text { Riverside } \\
\text { Beaver } \\
\text { School } \\
\text { District, No. } \\
\text { 05-1076 } \\
\text { (2005). }\end{array}$ & $\begin{array}{l}\text { Student wrote four rap songs } \\
\text { that were published on the } \\
\text { internet. One was about a } \\
\text { fellow student who moved as } \\
\text { a result of the comments. } \\
\text { The remaining three had } \\
\text { violent themes. Student was } \\
\text { suspended. }\end{array}$ & $\begin{array}{c}\text { Ruling: } \\
\text { Student } \\
\text { Standard: } \\
\text { Tinker }\end{array}$ & $\begin{array}{l}\text { Court found that there } \\
\text { was no substantial } \\
\text { disruption even } \\
\text { though a fellow } \\
\text { student felt the need } \\
\text { to switch schools. } \\
\text { Court also mentioned } \\
\text { that the fact that the } \\
\text { student had no history } \\
\text { of violence the } \\
\text { students mentioned } \\
\text { did not feel } \\
\text { threatened and if the } \\
\text { school did not treat } \\
\text { the matter as if the } \\
\text { student threatened } \\
\text { someone it could not } \\
\text { be taken as a true } \\
\text { threat. }\end{array}$ & $\begin{array}{l}\text { Schools must } \\
\text { demonstrate a substantial } \\
\text { disruption. If a school is } \\
\text { going to take action as if } \\
\text { a true threat were made } \\
\text { their actions should } \\
\text { reflect that by including } \\
\text { law enforcement } \\
\text { suggesting counseling or } \\
\text { taking other action to } \\
\text { reflect the serious nature } \\
\text { of a threat. }\end{array}$ \\
\hline $\begin{array}{c}\text { Requa v. } \\
\text { Kent School } \\
\text { District, } 492 \\
\text { F. Supp. 2d } \\
1272 \text { (2007). }\end{array}$ & $\begin{array}{l}\text { Student videotaped his } \\
\text { teacher at school with a } \\
\text { fellow student behind her } \\
\text { making pelvic thrusts and } \\
\text { giving bunny ears. Video } \\
\text { was posted on YouTube. } \\
\text { School became aware when a } \\
\text { news station called asking for } \\
\text { comment. Students involved } \\
\text { were given } 40 \text { day } \\
\text { suspensions with opportunity } \\
\text { to reduce to } 20 \text {. }\end{array}$ & $\begin{array}{c}\text { Ruling: } \\
\text { School } \\
\text { Standard: } \\
\text { Fraser }\end{array}$ & $\begin{array}{l}\text { Court stated that } \\
\text { school showed the } \\
\text { discipline was for the } \\
\text { lewd behavior in class } \\
\text { and not for the off- } \\
\text { campus posting of the } \\
\text { video. }\end{array}$ & $\begin{array}{l}\text { Schools maintain the } \\
\text { right to discipline for in } \\
\text { class behavior. The off- } \\
\text { campus speech twist of } \\
\text { this case does not negate } \\
\text { that right if the school } \\
\text { can demonstrate that the } \\
\text { discipline is for the in } \\
\text { class behavior. }\end{array}$ \\
\hline $\begin{array}{c}\text { Wisniewski } \\
\mathrm{v} \text {. Board of } \\
\text { Education of } \\
\text { the } \\
\text { Weedsport } \\
\text { Central } \\
\text { School } \\
\text { District, } 494 \\
\text { F. 3d 34 } \\
\text { (2007). }\end{array}$ & $\begin{array}{l}\text { Student created an instant } \\
\text { message icon that showed a } \\
\text { gun shooting his teacher. The } \\
\text { teacher refused to teach the } \\
\text { class with that student. } \\
\text { Student was suspended for } 5 \\
\text { days and had a hearing in that } \\
\text { time. At the hearing, school } \\
\text { called the icon a true threat } \\
\text { and suspended student for a } \\
\text { semester. }\end{array}$ & $\begin{array}{c}\text { Ruling: } \\
\text { School } \\
\text { Standard: } \\
\text { Tinker }\end{array}$ & $\begin{array}{l}\text { Court found that even } \\
\text { though the speech } \\
\text { was completely away } \\
\text { from school, it could } \\
\text { reasonably be thought } \\
\text { to create a substantial } \\
\text { disruption at school } \\
\text { when it was brought } \\
\text { to the attention of the } \\
\text { school. Court also } \\
\text { makes mention that } \\
\text { schools have broader } \\
\text { discretion than the } \\
\text { authorities would } \\
\text { have in dealing with a } \\
\text { true threat case. }\end{array}$ & $\begin{array}{l}\text { This finding and } \\
\text { rationale seem to go } \\
\text { against the above rulings } \\
\text { in what a school needs to } \\
\text { demonstrate in showing } \\
\text { a reasonable expectation } \\
\text { of substantial disruption. }\end{array}$ \\
\hline
\end{tabular}




\begin{tabular}{|c|c|c|c|c|}
\hline $\begin{array}{l}\text { Barnett v. } \\
\text { Tipton } \\
\text { County Board } \\
\text { of Education, } \\
\text { 601 F. Supp. } \\
\text { 2d 980 } \\
\text { (2009). }\end{array}$ & $\begin{array}{l}\text { Three students were involved } \\
\text { in making fake MySpace } \\
\text { pages for staff members with } \\
\text { pictures biographies and } \\
\text { inappropriate comments } \\
\text { about female students. All } \\
\text { three received in-school } \\
\text { suspensions for the websites. } \\
\text { One student then made a } \\
\text { wanted poster of a fellow } \\
\text { student he thought reported } \\
\text { him to the administration. } \\
\text { The student who created the } \\
\text { wanted poster was sent to an } \\
\text { alternative school and the } \\
\text { remaining students would } \\
\text { fulfill the in-school } \\
\text { suspensions when a hearing } \\
\text { was held on the matter. }\end{array}$ & $\begin{array}{l}\text { Ruling: } \\
\text { School } \\
\text { Standard: } \\
\text { None }\end{array}$ & $\begin{array}{l}\text { Court found in favor } \\
\text { of the school because } \\
\text { the student did not } \\
\text { demonstrate any } \\
\text { wrong-doing by the } \\
\text { school in terms of } \\
\text { First or Fourteenth } \\
\text { Amendments. The } \\
\text { students claimed that } \\
\text { the websites were } \\
\text { parodies but the court } \\
\text { found that a person } \\
\text { visiting the sites } \\
\text { would think the staff } \\
\text { members were } \\
\text { engaged in wrong- } \\
\text { doing and not that } \\
\text { they were parodies. }\end{array}$ & $\begin{array}{l}\text { The court in this case did } \\
\text { not touch on the off- } \\
\text { campus nature of the } \\
\text { speech and did not } \\
\text { address the Tinker } \\
\text { standard, but rather held } \\
\text { that the students did not } \\
\text { demonstrate that their } \\
\text { rights were violated. }\end{array}$ \\
\hline $\begin{array}{c}\text { Evans v. } \\
\text { Bayer, 684 F. } \\
\text { Supp. 2d } \\
1365(2010) .\end{array}$ & $\begin{array}{c}\text { Student created a Facebook } \\
\text { group about her dislike for a } \\
\text { teacher. After she removed it, } \\
\text { it was brought to the attention } \\
\text { of the principal and the } \\
\text { student was suspended for } 3 \\
\text { days. She was also moved } \\
\text { from an AP class to an honors } \\
\text { class. }\end{array}$ & $\begin{array}{l}\text { Ruling: } \\
\text { Student } \\
\text { Standard: } \\
\text { Tinker } \\
\text { (mention } \\
\text { Fraser and } \\
\text { Morse) }\end{array}$ & $\begin{array}{l}\text { Court found that the } \\
\text { school did not } \\
\text { demonstrate a } \\
\text { reasonable belief that } \\
\text { a substantial } \\
\text { disruption would } \\
\text { occur due to the off- } \\
\text { campus speech. In } \\
\text { fact the school was } \\
\text { not even aware of the } \\
\text { speech until after it } \\
\text { was removed. } \\
\text { Interestingly the court } \\
\text { mentioned that the } \\
\text { language did not } \\
\text { satisfy the description } \\
\text { of lewd found in } \\
\text { Fraser nor did it } \\
\text { undermine the } \\
\text { fundamental values of } \\
\text { the school like Morse. }\end{array}$ & $\begin{array}{l}\text { The Tinker standard of } \\
\text { substantial disruption } \\
\text { must be present to } \\
\text { discipline. This case } \\
\text { does open the door for } \\
\text { disciplining for off- } \\
\text { campus speech that } \\
\text { undermines the } \\
\text { fundamental values of } \\
\text { the school, as in the } \\
\text { Morse case. }\end{array}$ \\
\hline
\end{tabular}




\begin{tabular}{|c|c|c|c|c|}
\hline $\begin{array}{c}\text { J.C. v. } \\
\text { Beverly Hills } \\
\text { Unified } \\
\text { School } \\
\text { District, } 711 \\
\text { F. Supp. 2d } \\
\text { 1094 (2010). }\end{array}$ & $\begin{array}{l}\text { Student posted a YouTube } \\
\text { video of students making } \\
\text { hurtful comments about a } \\
\text { classmate. Student who } \\
\text { posted the video was } \\
\text { suspended for } 2 \text { days. }\end{array}$ & $\begin{array}{c}\text { Ruling: } \\
\text { Student } \\
\text { Standard: } \\
\text { Tinker }\end{array}$ & $\begin{array}{l}\text { Court found that the } \\
\text { Tinker standard was } \\
\text { not met on two levels } \\
\text { with the first being } \\
\text { there was no evidence } \\
\text { of a substantial } \\
\text { disruption. The court } \\
\text { went so far as to say } \\
\text { the school did not } \\
\text { show that the } \\
\text { administrators had to } \\
\text { alter their normal } \\
\text { routine in any way. } \\
\text { Additionally the } \\
\text { language in Tinker } \\
\text { that allows for } \\
\text { regulation of speech } \\
\text { if it interferes with } \\
\text { other students' rights } \\
\text { to be secure was not } \\
\text { met. }\end{array}$ & $\begin{array}{l}\text { Schools should tread } \\
\text { lightly when a clear } \\
\text { substantial disruption is } \\
\text { not present. This needs } \\
\text { to be weighed against } \\
\text { bullying and harassment } \\
\text { standards in such cases. }\end{array}$ \\
\hline $\begin{array}{c}\text { Donniger v. } \\
\text { Niehoff, } 527 \\
\text { F. 3d } 31 \\
(2008)\end{array}$ & $\begin{array}{l}\text { Student criticized } \\
\text { administration for } \\
\text { rescheduling an event and } \\
\text { called them "douche bags." } \\
\text { Called on other students to } \\
\text { contact the administration } \\
\text { about the event. Student was } \\
\text { banned from running for } \\
\text { student council the following } \\
\text { year. }\end{array}$ & $\begin{array}{l}\text { Ruling: } \\
\text { School } \\
\text { Standard: } \\
\text { Tinker }\end{array}$ & $\begin{array}{l}\text { Court upheld that a } \\
\text { substantial disruption } \\
\text { did in fact occur as } \\
\text { numerous phone calls } \\
\text { reached the school } \\
\text { regarding the } \\
\text { rescheduled event } \\
\text { after Donniger's } \\
\text { actions. Court made } \\
\text { mention that } \\
\text { punishment may not } \\
\text { fit the crime, but the } \\
\text { court was not going to } \\
\text { undermine schools } \\
\text { without specific } \\
\text { constitutional } \\
\text { violations. }\end{array}$ & $\begin{array}{l}\text { Schools must rely on the } \\
\text { substantial disruption } \\
\text { element of Tinker, even } \\
\text { when uncertain. The } \\
\text { court here seems to err in } \\
\text { favor of schools when no } \\
\text { constitutional offenses } \\
\text { have occurred, unlike } \\
\text { some cases above. }\end{array}$ \\
\hline $\begin{array}{l}\text { J.S. v. Blue } \\
\text { Mountain } \\
\text { School } \\
\text { District, no. } \\
08-4138, \\
2011 \mathrm{WL} \\
2305973 \\
(2011) .\end{array}$ & $\begin{array}{l}\text { Student created a fake } \\
\text { MySpace page about the } \\
\text { principal which personally } \\
\text { attacked the principal in a } \\
\text { shameful nature. Student } \\
\text { allowed another student to } \\
\text { access the site at school and } \\
\text { was suspended } 10 \text { days. } \\
\text { During the course of the trial } \\
\text { the school conceded there } \\
\text { was not a substantial } \\
\text { disruption to the school } \\
\text { environment. }\end{array}$ & $\begin{array}{l}\text { Ruling: } \\
\text { Student } \\
\text { Standard: } \\
\text { Tinker } \\
\text { (mentions } \\
\text { Fraser and } \\
\text { Morse) }\end{array}$ & $\begin{array}{l}\text { Court pointed out that } \\
\text { the school's } \\
\text { recognition that there } \\
\text { was no substantial } \\
\text { disruption left no } \\
\text { grounds for discipline } \\
\text { to be issued. The } \\
\text { point that if black } \\
\text { armbands of Tinker } \\
\text { were not grounds for } \\
\text { discipline then neither } \\
\text { were the facts of this } \\
\text { case. The principal } \\
\text { disciplined only } \\
\text { because the language } \\
\text { was disagreeable. }\end{array}$ & $\begin{array}{l}\text { Schools must meet the } \\
\text { substantial disruption } \\
\text { standard of Tinker. } \\
\text { Court mentions Fraser } \\
\text { and Morse even though } \\
\text { the facts of this case do } \\
\text { not directly relate to } \\
\text { those cases. }\end{array}$ \\
\hline
\end{tabular}




\begin{tabular}{|c|c|c|c|c|}
\hline $\begin{array}{l}\text { Layshock v. } \\
\text { Hermitage } \\
\text { School } \\
\text { District, No. } \\
07-4465, \\
2011 \mathrm{WL} \\
2305970 \\
(2011) .\end{array}$ & $\begin{array}{l}\text { Student created a fake } \\
\text { MySpace page about the } \\
\text { principal that was insulting } \\
\text { but not threatening. Student } \\
\text { was suspended } 10 \text { days, } \\
\text { removed from honors classes } \\
\text { and placed in an alternative } \\
\text { program, and banned from } \\
\text { any extracurricular } \\
\text { participation including } \\
\text { graduation. }\end{array}$ & $\begin{array}{l}\text { Ruling: } \\
\text { Student } \\
\text { Standard: } \\
\text { Tinker } \\
\text { (mentions } \\
\text { Fraser) }\end{array}$ & $\begin{array}{l}\text { Court points out that } \\
\text { there was no } \\
\text { substantial disruption } \\
\text { to the school so the } \\
\text { speech essentially is } \\
\text { off-campus speech. } \\
\text { Other standards do } \\
\text { not apply to off- } \\
\text { campus speech. }\end{array}$ & $\begin{array}{l}\text { Schools must meet the } \\
\text { substantial disruption } \\
\text { test of Tinker to } \\
\text { discipline. Fraser again } \\
\text { referenced though not } \\
\text { applied. }\end{array}$ \\
\hline $\begin{array}{l}\text { Kowalski v. } \\
\text { Berkeley } \\
\text { County } \\
\text { Schools, No. } \\
10-1098, \\
2011 \mathrm{WL} \\
3132523 \\
(2011)\end{array}$ & $\begin{array}{l}\text { Student created a MySpace } \\
\text { page that ridiculed one } \\
\text { particular classmate and } \\
\text { suggested that another } \\
\text { classmate had an STD. } \\
\text { Student was suspended for } 5 \\
\text { days and received a } 90 \text { day } \\
\text { social suspension. }\end{array}$ & $\begin{array}{c}\text { Ruling: } \\
\text { School } \\
\text { Standard: } \\
\text { Tinker }\end{array}$ & $\begin{array}{l}\text { Court found the } \\
\text { student speech to be } \\
\text { outside the protection } \\
\text { of the First } \\
\text { Amendment and not } \\
\text { the type of speech the } \\
\text { educational system } \\
\text { had to tolerate. } \\
\text { School system was } \\
\text { within their bounds as } \\
\text { trustees of student } \\
\text { body's well-being in } \\
\text { issuing discipline to } \\
\text { protect other students. }\end{array}$ & $\begin{array}{l}\text { While the continuing } \\
\text { theme of using the } \\
\text { Tinker standard was } \\
\text { active in this case, it was } \\
\text { applied much more } \\
\text { generously in the } \\
\text { school's favor than other } \\
\text { cases. Court actually } \\
\text { used terms bullying and } \\
\text { harassment in describing } \\
\text { why the student behavior } \\
\text { was wrong. }\end{array}$ \\
\hline $\begin{array}{l}\text { Mardis v. } \\
\text { Hannibal } \\
\text { Public School } \\
\text { District, No. } \\
\text { 10-1428, } \\
2011 \text { WL } \\
3241876 \\
\text { (2011). }\end{array}$ & $\begin{array}{l}\text { Student sent IM to classmate } \\
\text { that he was going to get a gun } \\
\text { and kill several classmates } \\
\text { and wanted to make sure the } \\
\text { school was known for } \\
\text { something. Student was } \\
\text { taken into custody placed in } \\
\text { juvenile detention and then } \\
\text { into a psychiatric hospital. } \\
\text { Student was suspended from } \\
\text { school until the end of the } \\
\text { school year. }\end{array}$ & $\begin{array}{c}\text { Ruling: } \\
\text { School } \\
\text { Standard: } \\
\text { Watts (true } \\
\text { threat) \& } \\
\text { Tinker }\end{array}$ & $\begin{array}{l}\text { Court first found that } \\
\text { the speech was a true } \\
\text { threat and therefore } \\
\text { not protected First } \\
\text { Amendment Speech. } \\
\text { Secondly the schools } \\
\text { could step in and } \\
\text { issue discipline } \\
\text { because the } \\
\text { statements } \\
\text { substantially } \\
\text { disrupted the school } \\
\text { environment. }\end{array}$ & $\begin{array}{l}\text { The school included law } \\
\text { enforcement from the } \\
\text { beginning and treated the } \\
\text { comments as if they } \\
\text { were going to be carried } \\
\text { out. This is important if } \\
\text { a school administrator } \\
\text { believes they are in fact } \\
\text { a true threat. The court } \\
\text { here again uses Tinker in } \\
\text { a more school-supportive } \\
\text { manner in defining what } \\
\text { exactly a substantial } \\
\text { disruption is. }\end{array}$ \\
\hline $\begin{array}{l}\text { TV ex rel BV } \\
\text { v. Smith- } \\
\text { Green } \\
\text { Community } \\
\text { School } \\
\text { Corporation, } \\
\text { No. 1:09-CV- } \\
\text { 290-PPS, } \\
\text { 2011 WL } \\
\text { 3501698 } \\
\text { (2011). }\end{array}$ & $\begin{array}{l}\text { Two students took pictures of } \\
\text { themselves pretending to suck } \\
\text { phallic shaped suckers in } \\
\text { various poses and posted the } \\
\text { images to social media } \\
\text { websites. A parent brought } \\
\text { the images to the } \\
\text { superintendent's attention and } \\
\text { stated the pictures were } \\
\text { causing problems on the } \\
\text { volleyball team. The two } \\
\text { girls were suspended } 25 \% \text { of } \\
\text { the season under the } \\
\text { extracurricular code of } \\
\text { conduct. }\end{array}$ & $\begin{array}{c}\text { Ruling: } \\
\text { Student } \\
\text { Standard: } \\
\text { Tinker }\end{array}$ & $\begin{array}{l}\text { Court found in favor } \\
\text { of the student since } \\
\text { the only disruption } \\
\text { was some arguing } \\
\text { between } 15 \text { year olds } \\
\text { at practice and an } \\
\text { upset parent. Court } \\
\text { pointed out that the } \\
\text { code of conduct } \\
\text { provision that } \\
\text { addressed this issue } \\
\text { was overly vague as it } \\
\text { did not describe what } \\
\text { actions would be } \\
\text { problematic. }\end{array}$ & $\begin{array}{l}\text { This case is the first to } \\
\text { challenge the code of } \\
\text { conduct penalties and } \\
\text { not the actual academic } \\
\text { day penalties for off- } \\
\text { campus speech. } \\
\text { Administrators must note } \\
\text { that Tinker still applies } \\
\text { to the code of conduct. }\end{array}$ \\
\hline
\end{tabular}




\title{
APPENDIX B
}

\section{ADMINISTRATIVE CONSIDERATION TOOL}

\begin{abstract}
A) Did the speech occur at school, did it originate using school technology, or was it transmitted via school technology? No $\rightarrow$ See $(\mathrm{C}) \quad$ Yes $\rightarrow$ Discipline accordingly
\end{abstract}

B) Contact Law enforcement

C) Follow prescription of Code of Conduct if behavior falls under those guidelines.

Was the speech protected speech? Did the speaker:

1) Communicate a serious expression of intent to commit an act of unlawful violence to a person or group?

2) Use words that by their very utterance inflict injury or tend to incite an immediate reaction?

3) Offer to engage in illegal transactions?

4) Define sexual activity in an offensive way or in a manner lacking artistic, scientific, artistic, or political value?

5) Use speech containing sexually explicit visual portrayals of children?
No -> Proceed to next level
Yes $->$ See (A) and (B) above

Did the speech violate a state cyberbullying or harassment law?

1) Reference state laws

2) Contact law enforcement for clarification.

No -> Proceed to next level

Yes $->$ See (A) and (B) above

Does the speech pass the Tinker standard - part I? Did/was the speech:

1) Originate at school?

2) Transmitted or accessed at school or using a school computer?

3) Occur due to or involve some connection, or nexus, to the school?

No -> Proceed to next level

Yes -> Discipline accordingly

Did the speech occur via a school activity or in conjunction $\mathrm{w} /$ other pedagogical concerns, such as but not limited to:

1) School-Sponsored Newspaper

2) School-Sponsored TV

3) School-Sponsored Website/ blog/ etc.

No $->$ Proceed to next level

Yes -> Discipline accordingly

Does the speech pass the Tinker standard - part II? Did(could) the speech:

1) Cause a material or substantial disruption to the normal operation of school?

2) Potentially create a material or substantial disruption to the normal operation of school?

No $->$ Proceed to next level

Yes -> Discipline accordingly

Does the speech expose students to language that is:

1) Inappropriate

2) Illegal 


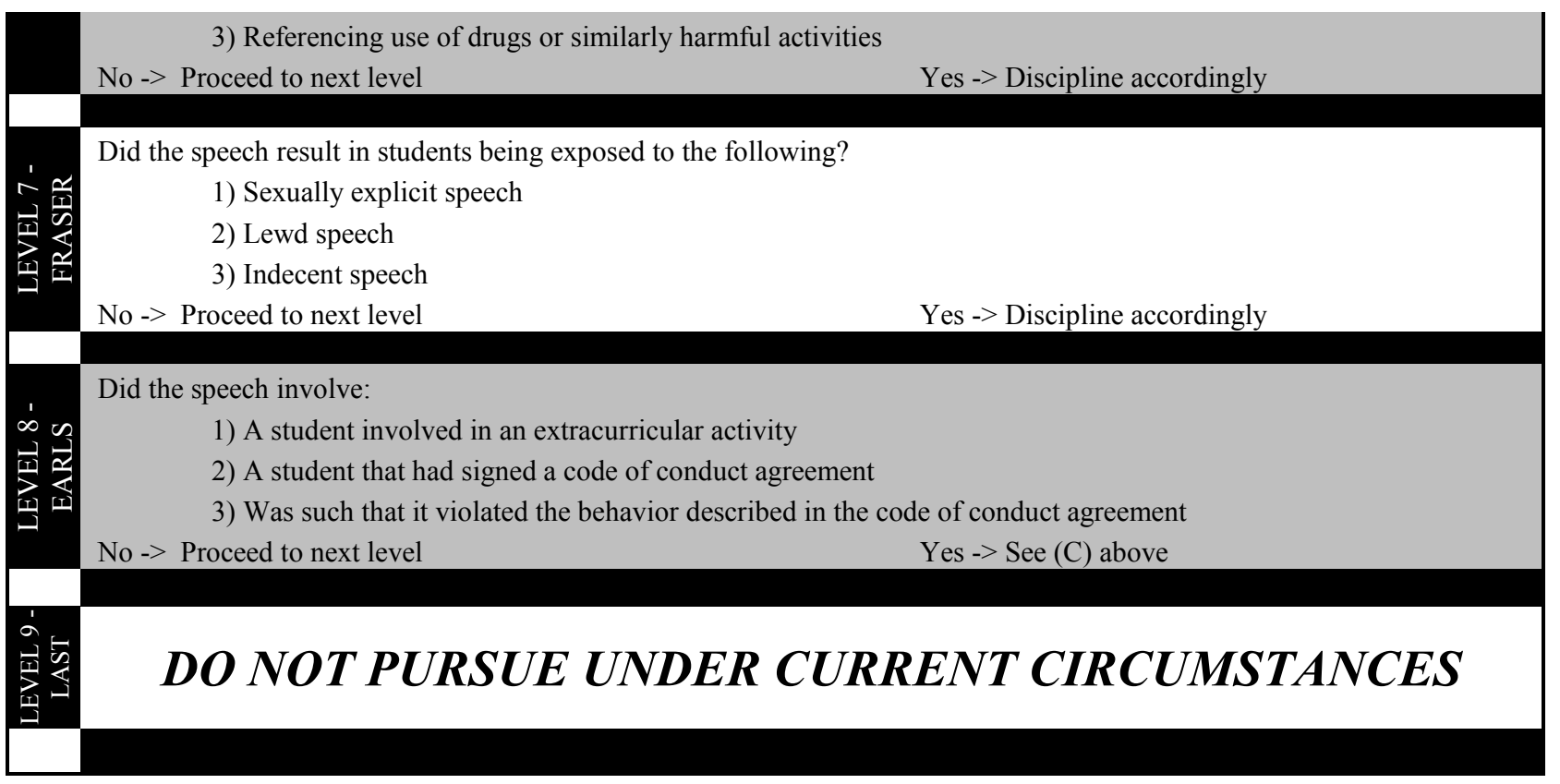

